Viviane Panelli Sarraf

\title{
Reabilitação do Museu: Políticas de Inclusão Cultural por meio da Acessibilidade
}

Dissertação apresentada ao Programa de Pós-Graduação em Ciência da Informação, Área de Concentração Cultura e Informação, Linha de Pesquisa Mediação e Ação Cultural, da Escola de Comunicações e Artes da Universidade de São Paulo, como exigência parcial para obtenção do Título de Mestre em Ciência da Informação, sob a orientação do Prof. Titular Martin Grossmann.

São Paulo 
Viviane Panelli Sarraf

\section{Reabilitação do Museu: Políticas de Inclusão Cultural por meio da Acessibilidade}

Dissertação apresentada ao Programa de Pós-Graduação em Ciência da Informação, Área de Concentração Cultura e Informação, Linha de Pesquisa Mediação e Ação Cultural, da Escola de Comunicações e Artes da Universidade de São Paulo, como exigência parcial para obtenção do Título de Mestre em Ciência da Informação, sob a orientação do Prof. Titular Martin Grossmann.

São Paulo 
Sarraf, Viviane Panelli

Reabilitação do Museu: políticas de inclusão cultural por meio da acessibilidade/ Viviane Panelli Sarraf. - - São Paulo: V. Sarraf, 2008.

180p.: II.

Dissertação (Mestrado) - Departamento de Ciência da Informação/Escola de Comunicações e Artes/USP.

Orientador: Prof. Dr. Titular Martin Grossmann

Bibliografia

1.Acessibilidade em Museus 2. Inclusão Social em Museus 3. Pessoas com Deficiência em Museus 5. Sarraf, Viviane Panelli I. Grossmann, Martin II. Título. 
Folha de aprovação

Nome do autor: Viviane Panelli Sarraf

Título e subtítulo: Reabilitação do Museu: políticas culturais de inclusão social por meio da acessibilidade

Natureza do trabalho: Dissertação

Grau pretendido: Mestre

Nome da Instituição: Universidade de São Paulo

Área de Concentração: Ação e Mediação Cultural

Data de aprovação:

Componentes da Banca:

Nome:

Titulação:

Instituição à que pertence:

Assinatura:

Nome:

Titulação:

Instituição à que pertence:

Assinatura:

Nome:

Titulação:

Instituição à que pertence:

Assinatura: 
Dedicatória:

Ao Pedro e à Maria, meus filhinhos lindos.

À minha querida avó Olga, que não pode ver este trabalho completo em vida, mas se orgulhou e ofereceu todo seu apoio e carinho em vida. 


\section{Agradecimentos:}

Agradeço:

Incondicionalmente aos meus filhos Pedro e Maria, que entenderam esse projeto, apoiaram-me, acompanharam-me e me fizeram relaxar com seus sorrisos nos momentos críticos. Ao meu marido José, que cuidou dos filhos, leu o texto, criticou, apoiou, cozinhou e me acompanhou sempre que necessário.

Às grandes mulheres Dorina de Gouvêa Nowill, que luta há mais de 60 anos pela inclusão das pessoas com deficiência e que ainda arruma tempo para visitar museus e gostar deles, e à minha avó Olga Dabague Panelli, bibliotecária pioneira que trabalhou a rede de bibliotecas de leprosários e centros de estudo em hanseníase na década de 1930.

Reconheço toda a paciência e atenção de meu orientador Martin Grossmann, exemplo de diplomacia, integração e reflexão sobre o que há de mais inovador na área da arte e cultura e por ter aceitado orientar meu trabalho de tema polêmico e em fase de legitimação.

Às pessoas que cederam tempo para dar seus depoimentos para esta pesquisa e que aceitaram sua análise nesta dissertação a fim de colaborar para as reflexões teóricas sobre a inclusão cultural.

Aos profissionais que me receberam nos museus e exposições para visitas técnicas e que tanto contribuíram com esta pesquisa.

Com carinho, aos professores, amigos e colegas de jornada na área de museus e inclusão que ajudaram, apoiaram, divulgaram, elogiaram, convidaram, indicaram...

À Artemisia, organização que acreditou em meu trabalho e atualmente continua acreditando e apoiando a acessibilidade em museus como um empreendimento sustentável para a sociedade contemporânea.

Enfim, à vida, à natureza, ao acaso e a Deus. 


\section{Resumo:}

A pesquisa "Reabilitação do Museu: Políticas de Inclusão Cultural por meio da Acessibilidade" investiga a relação museu e pessoas com deficiência analisando as teorias e práticas voltadas à ação cultural e programas inclusivos. Investiga também os conceitos de inclusão e acessibilidade em relação ao museu e à mediação cultural, utilizando para tanto os depoimentos de integrantes dos dois lados do sistema pesquisado: pessoas com deficiência representando o público beneficiário e gestores das instâncias pública e privada representando os museus e instituições culturais.

A finalidade desta dissertação é demonstrar a necessidade de uma nova forma de atuação institucional que leve em consideração o direito e o desejo das pessoas com deficiência em se beneficiarem com o acesso à cultura, à arte e ao patrimônio cultural, o que implica conseqüentemente, em novas estratégias de mediação e acesso à informação na gestão de equipamentos culturais.

A pesquisa oferece subsídios práticos e teóricos para a implantação de políticas culturais que promovam o acesso à informação, ao patrimônio e às atividades culturais para pessoas com deficiência e mobilidade reduzida, com a possibilidade de extensão destes benefícios para outros públicos.

Palavras-chave: acessibilidade - inclusão - museu - pessoas com deficiência política cultural

\section{Abstract:}

The research "Rehabilitation of Museum: Policies of Cultural Inclusion through Accessibility" investigates the relationship between museums and people with disabilities by the analysis of practices and theories about cultural actions and inclusive programs. Also investigate the accessibility and inclusion concepts in relation to museums and cultural mediation using for this objective the testimony of people representing the two sides of this system: people with disabilities - the target audience, and directors and cultural agents of public and private museums and cultural institutions.

This research aim to show the necessity of a new way of institutional action that consider the desire and rights of people with disabilities in have benefits with the cultural, artistic and heritage access, that force this spaces to develop new forms of mediation and access to the information in the administration of this spaces .

The research offer practical and theory subsidy to the creation of cultural politicies to promote access to information, heritage and cultural activities for people with disabilities and reduced mobility, with the possibility of extension of this benefits for other visitors.

Key words: accessibility - inclusion - museum - people with disabilities - cultural policy. 


\section{Lista de Siglas}

ABNT - Associação Brasileira de Normas Técnicas

AFB - American Foundation for the Blind (Fundação Americana para os Cegos)

CEMMAE - Curso de Especialização em Museologia do Museu de Arqueologia e Etnologia

CIF - Classificação Internacional de Funcionalidade

ECA - Escola de Comunicações e Artes

FUNARTE - Fundação Nacional da Arte

IBGE - Instituto Brasileiro de Geografia e Estatística

ICOM - International Council of Museums (Conselho Internacional de Museus)

IPHAN - Instituto do Patrimônio Histórico e Artístico Nacional

LIBRAS - Língua Brasileira de Sinais

MAC - Museu de Arte Contemporânea

MAM - Museu de Arte Moderna

MASP - Museu de Arte de São Paulo

NBR - Norma Brasileira (da ABNT)

ONCE - Organización Nacional de Ciegos de España (Organização Nacional de Cegos da Espanha)

OMS - Organização Mundial de Saúde

ONU - Organização das Nações Unidas

SMPED - Secretaria Municipal da Pessoa com Deficiência

USP - Universidade de São Paulo

WCWB - World Council for Welfare to the Blind (Conselho Mundial de Atenção aos Cegos 


\section{Lista de Imagens}

Figura 1. Projeto de Ação Educativa para Deficientes Visuais, Museu de Zoologia da USP, 2006.

Figura 2. Programa Igual Diferente, MAM -SP, 2006.

Figura 3. PEPE- Programa Educativo para Público Especial, Pinacoteca do Estado de São Paulo, 2006.

Figura 4. ECCO - Espaço físico acessível, 2006.

Figura 5. ECCO - Treinamento da equipe para trabalho com pessoas com deficiência, 2006.

Figura 6. Projeto de Ação Educativa para Deficientes Visuais - Museu de Zoologia, 2006.

Figura 7. Exposição "A Célula ao Alcance das Mãos" - Biblioteca do Campus Universitário do SENAC, 2007.

Figura 8. Curso de História da Arte para Cegos - MASP, 2006.

Figura 9. Curso de Formação de Educadores Surdos - MAM-SP, 2006.

Figura 10. Exposição "Corpos Humanos” - OCA, 2007.

Figura 11. Exposição "Poética da Percepção" - Espaço Cultural Vivo, 2007.

Figura 12. Projeto de Clima - Olafur Eliasson, Tate Modern, 2003.

Figura 13. O Espelho Cego - Cildo Meireles, coleção particular, 1970.

Figura 14. O Eu e o Tu - Lygia Clark, 1967. 


\section{SUMÁRIO}

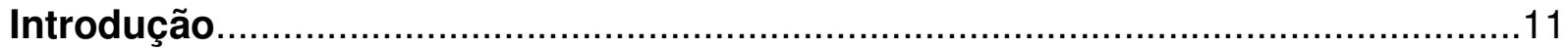

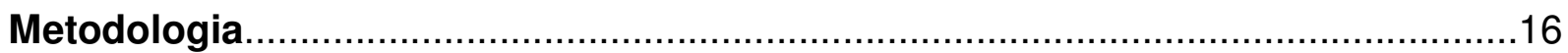

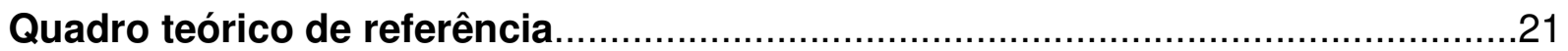

Capítulo 1 - A relação entre os museus e as pessoas com deficiência sob

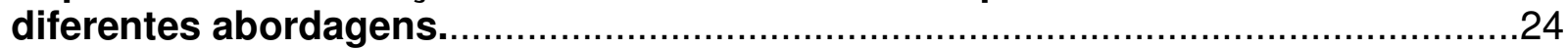

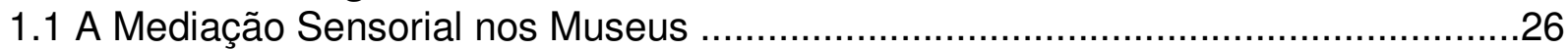

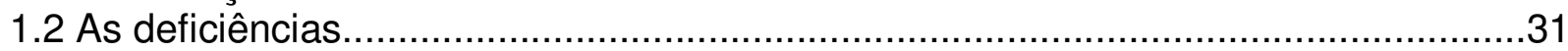

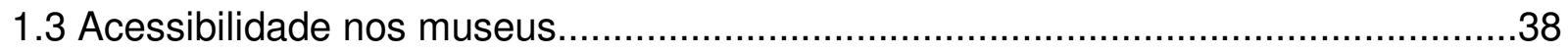

1.4 A Inclusão das Pessoas com Deficiência nos Museus...........................................44

Capítulo 2 - Análise histórica do processo de acessibilidade em museus: uma revisão dos movimentos das pessoas com deficiência $e$ das diretrizes museológicas estabelecidas pelo ICOM - International Council of Museums.

2.1 As conquistas dos movimentos de Inclusão Social e as mudanças na dinâmica dos museus durante a revolução cultural........................................................................52

2.2 As Mudanças na definição de museu segundo o ICOM.......................................60

$2.3 \mathrm{O}$ desafio da acessibilidade em museus...............................................................64

Capitulo 3 - Políticas culturais de acessibilidade em museus sob o ponto de vista dos gestores culturais e das pessoas com deficiência........................................73

Uma análise realizada com atores reais do processo de inclusão..............................74

3.10 que dizem os gestores culturais das políticas culturais acessíveis às pessoas com

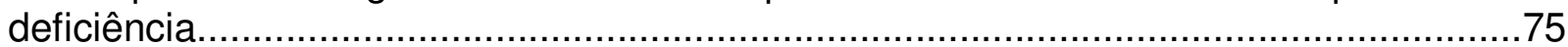

3.2 O que dizem as pessoas com deficiência das políticas culturais acessíveis aos seus

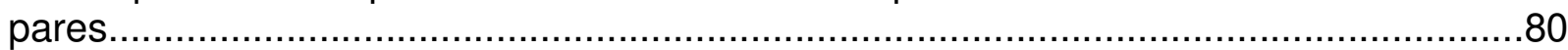

3.3 Ofertas de Acessibilidade em Museus Brasileiros - relato crítico do cenário atual da acessibilidade em museus e equipamentos culturais...............................................8

Conclusões Finais - Considerações e subsídios sobre Políticas Culturais de Acessibilidade em Museus......................................................................... 101

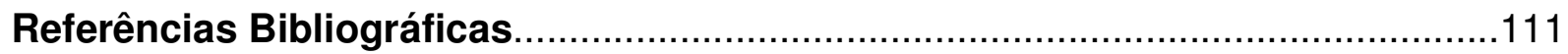

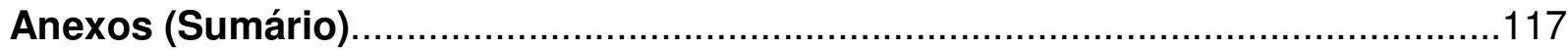

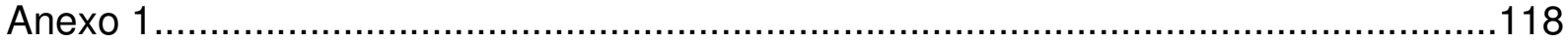

Anexo 2

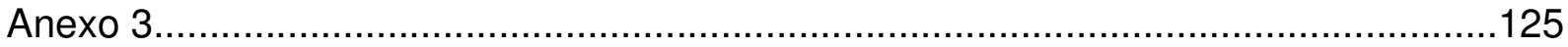




\section{Introdução}

A pesquisa "Reabilitação do Museu: Políticas de Inclusão Cultural por meio da Acessibilidade" apresenta a questão da inclusão e da acessibilidade para pessoas com deficiência em museus. Para tanto, utiliza-se de referenciais teóricos, análise dos principais e atuais fatos ligados ao tema, depoimentos colhidos com representantes das esferas envolvidas no problema da pesquisa (pessoas com deficiência e gestores culturais) e visitas técnicas às instituições culturais em suas ofertas voltadas ao público em questão.

As bases teóricas deste estudo e reflexão se dão de forma interdisciplinar, dialogando com a Ação e Mediação Cultural, com a Museologia, com a História, com a Sociologia, com os Movimentos de Inclusão Social e de Defesa dos Direitos Humanos, com a Educação Inclusiva, com a Arte-Educação, com a Filosofia e com as Artes.

As reflexões e proposições presentes neste texto baseiam-se nas relações sociais entre duas esferas: a dos museus e instituições culturais e a das pessoas com deficiência. Tal esforço tem como finalidade identificar possíveis intersecções que resultem em subsídios para ações e políticas culturais que beneficiem os envolvidos de ambas as esferas. Os museus e instituições culturais, desde a segunda metade do século XX, movem esforços para afirmar seu caráter de agente de desenvolvimento social negando sua ligação de origem com as elites e com o poder, por meio do trabalho centrado no indivíduo e nas comunidades. As pessoas com deficiência, que durante séculos foram excluídas do convívio social, hoje representam uma população social e economicamente ativa que vem conquistando espaço na mídia, no ambiente acadêmico, no poder público e nas manifestações culturais, contribuindo para novas formas de concepção de produtos e serviços que privilegiem a diferença, a ergonomia, a melhoria de qualidade de vida e a acessibilidade.

O Movimento de Inclusão Social liderado por pessoas com deficiência, em várias partes do mundo desde a década de 1980, vem sendo considerado um dos mais ativos e militantes por autores e jornalistas da área de ciências políticas. Com inspiração na Declaração Internacional de Direitos Humanos, esse movimento já conseguiu a 
promulgação de algumas declarações, leis, normas, estatutos e outras conquistas políticas em relação aos direitos das pessoas com deficiência.

Faz-se necessário esclarecer, no entanto, que o termo 'direitos humanos', amplamente utilizado como forma de garantia de condições igualitárias para todos os indivíduos, independente de sua origem, gênero, poder aquisitivo e condição social, nem sempre recebeu essa conotação. No contexto de criação deste termo, durante a Revolução Francesa, os militantes buscavam uma forma de legitimar os direitos da população, que eram todos aqueles que não pertenciam à nobreza. Assim, de 'direitos dos franceses', termo já existente para garantir os benefícios aos nobres, a denominação foi modificada para 'direitos humanos' para diferenciar a população do rei e da corte. O que presenciamos atualmente fora dos discursos ideológicos em nada se aproxima da idéia de igualdade que o originou. As desigualdades sociais, a perda da condição de 'bem estar social', o preconceito e a restrição de acesso à informação são características comuns à sociedade contemporânea, apesar de teoricamente serem fatos condenáveis.

A reivindicação ao 'humano' pelos revolucionários franceses parece inteiramente injustificada e, até mesmo, desnecessária. Exceto por algumas considerações importantes. Em primeiro lugar, direitos dos franceses era um termo já usado na prática. Formalmente os direitos da França eram os direitos do rei, é verdade que bastante modificados para garantir a proveniência de alguns outros grupos. Os direitos dos franceses podiam ser interpretados de forma radical: em contraste com direitos realmente possuídos pela população em geral ou direitos afirmados como possibilidades futuras pela população em geral. (POSTER, 2003 p. 317 in Por uma outra Comunicação. MORAES org.)

Segundo a crítica apresentada por Poster, o termo humano tinha como função igualar socialmente as populações de diferentes origens, presentes na França no século XVIII, por meio de direitos iguais para todos. Nesse sentido, todos os indivíduos deveriam ter o mesmo acesso às condições de vida, o que não acontecia de fato. $O$ termo 'cidadão' surgiu, pois, pela necessidade de produzir na prática os direitos humanos. A prática do cidadão foi o que tornou reais os direitos humanos que, por sua vez, compuseram os parâmetros do conceito de cidadania.

Neste primeiro movimento, as pessoas com deficiência não estavam contempladas pelos direitos atribuídos aos cidadãos, pois a exclusão social de 
indivíduos com deficiência física, auditiva, visual, múltipla e intelectual era praticada de forma indiscriminada. Uma minoria desta população era nascida em famílias abastadas e mais esclarecidas e, por sua vez, recebiam atenção diferenciada e tinham acesso ao desenvolvimento pessoal; os demais indivíduos integrantes de famílias menos favorecidas eram relegados ao anonimato, escondidos por seus familiares, expulsos das comunidades ou internados em sanatórios completamente afastados dos centros urbanos.

Os primeiros movimentos sociais ativos em defesa dos direitos das pessoas com deficiência foram iniciados apenas no século XX. Com o término da Segunda Guerra Mundial, em 1945, a partir deste momento a deficiência passou a ser uma realidade para a população européia, já que civis e soldados adquiriram deficiências visuais, auditivas, físicas e doenças mentais em decorrência de batalhas armadas e seus efeitos colaterais. Inevitavelmente, uma maior atenção às deficiências se tornou necessária, tanto na esfera pública como na privada, impulsionada também pela ação dos primeiros órgãos de defesa dos direitos humanos e dos deficientes.

Algumas décadas depois, ao término da Guerra do Vietnã, soldados americanos retornavam aos EUA com diversas deficiências. As manifestações sociais por direitos dos indivíduos mutilados pela guerra, impulsionadas pelo movimento estudantil, gerou o primeiro movimento organizado pelo direito das pessoas com deficiência: a Integração Social, superado na década de oitenta pelos conceitos do movimento de Inclusão Social que permanece ativo até o momento.

O movimento, que continua militante na sociedade, defende parâmetros de dignidade para pessoas com deficiência, lutando pela equiparação de oportunidades. No entanto, se os direitos inerentes às pessoas, independente de sua condição física e intelectual, fossem realmente garantidos, não existiria mais razão para a criação de novos movimentos em defesa dos direitos dos cidadãos, pois, como afirma Baudrillard: 'Por paradoxal que possa parecer, não é pelos direitos do homem que transpiram hoje - em nível planetário - as piores discriminações?" (POSTER apud BAUDRILLARD, 2003: 315) 
Desde a criação do termo Direitos Humanos até a situação atual de valorização e empowerment das pessoas com deficiência e mobilidade reduzida, os museus passaram por um processo intenso de mudança. Mesmo com o boom de construção de novos museus na década de 1980 e da revitalização de outros, para uma considerável parte da população os museus não são uma prioridade em suas opções de lazer e cultura. Com o objetivo de manter uma imagem de vanguarda, as instituições culturais têm feito uso de recursos tecnológicos de ponta, bem como providenciado adequações espaciais visando atrair para seu interior novos públicos nunca imaginados em sua trajetória histórica.

As pessoas com deficiência, a população de terceira idade e as comunidades culturalmente excluídas representam hoje um público potencial para os museus. Importantes instituições internacionais realizam pesquisas e propostas de mediação participativa, estratégias de acolhimento e permanência dos visitantes nos imponentes edifícios que abrigam os museus, roteiros de visita destinados a diferentes interesses e, em grande parte destes equipamentos, sólidos programas de acessibilidade para este público.

Também é necessário considerar que todos nós, independente de classe social ou desenvolvimento intelectual, somos potenciais pessoas com deficiência e mobilidade reduzida. Além do aumento da expectativa de vida que traz consigo dificuldades de locomoção, doenças mentais e perda progressiva dos sentidos, a violência urbana e a dinâmica das metrópoles colocam nossos corpos em situações de risco que podem causar perda de visão, audição, mobilidade e saúde mental. É possível notar o grande número de jovens com deficiência física que adquiriram a condição em acidentes de automóvel ou na prática de esportes 'radicais', o aumento do número de pessoas com deficiência visual causadas por balas-perdidas ou assaltos à mão-armada, o aumento de pessoas com paralisias por conta de doenças cardiovasculares impulsionadas pelo estresse da vida cotidiana.

Estas informações contribuem para a compreensão de que encontrar caminhos para inclusão de pessoas com deficiência nos museus é garantir que todos aqueles que 
tenham desejo de se beneficiar deste equipamento não sejam excluídos por conta de diferentes formas de locomoção, cognição e percepção.

A acessibilidade também tem o potencial de beneficiar todos os públicos que freqüentam o museu e cativá-los, para que este se torne um equipamento de referência na dinâmica social contemporânea. Espaços que respeitam a diversidade, que proporcionam acolhimento, que oferecem recursos para facilitar a permanência dos visitantes em suas dependências, que proporcionam maneiras facilitadas de acessar a informação e conteúdos tornam-se mais atrativos para todos os seus freqüentadores.

Levando em consideração esses aspectos, cabe a este trabalho, analisar criticamente teorias e casos de ação e mediação cultural com inclinações para a inclusão de pessoas com deficiência e mobilidade reduzida em museus, a fim de indicar problemas e encontrar caminhos para o desenvolvimento qualificado de políticas culturais desta natureza em instituições brasileiras. 


\section{Metodologia}

A metodologia da pesquisa priorizou a efetivação de um estudo que considerasse os diversos aspectos da situação da acessibilidade para pessoas com deficiência em museus e pudesse oferecer subsídios para comprovar a necessidade de criação de políticas culturais de acesso e inclusão.

Encontrar uma bibliografia que oferecesse um parecer teórico sobre a inclusão e a acessibilidade de pessoas com deficiências em museus não foi uma tarefa fácil, pois existe uma gama de publicações técnicas sobre o assunto que, entretanto, se apresentam como relatos de experiências de países, estados, cidades ou mesmo instituições. Esses relatos, entretanto, ainda não se configuraram como teorias de apoio às pesquisas congêneres; dessa forma, tornou-se necessário estabelecer aproximações com as teorias da Ciência da Informação, Ciências Sociais, Estudos Culturais, Museologia, História da Arte, Filosofia, História e Educação para fundamentar esta dissertação.

Os critérios de busca de bibliografia priorizaram as pesquisas em bases de dados: Dedalus - USP e catálogos locais de bibliotecas que pudessem conter publicações de temas correlatos ao pesquisado - Biblioteca do Museu de Arqueologia e Etnologia da USP (contém o acervo bibliográfico do Curso de Especialização em Museologia ministrado em quatro edições neste museu), Biblioteca da Escola de Comunicações e Artes da USP (contém o acervo bibliográfico dos cursos de graduação e pós-graduação em Artes, Biblioteconomia, Comunicação, Ciência da Informação e áreas correlatas à pesquisa), Biblioteca da Faculdade de Filosofia Letras e Ciências Humanas da - USP (contém o acervo bibliográfico dos cursos de graduação e pós-graduação em filosofia, ciências sociais, antropologia, história e outras áreas correlatas à pesquisa), Biblioteca do Museu de Arte Contemporânea da USP (contém acervo bibliográfico sobre as pesquisas acerca de museologia e ação cultural desenvolvidas pelos docentes que atuam e atuaram na instituição), Biblioteca da Faculdade de Educação da USP (contém o acervo bibliográfico dos cursos de graduação e pós-graduação em educação que têm disciplinas sobre educação especial e inclusão de pessoas com deficiência), Biblioteca 
da Fundação Dorina Nowill para Cegos (contém acervo bibliográfico referente aos trabalhos de inclusão promovidos pela instituição e pesquisas de seus colaboradores desde 1946).

A insatisfação com as publicações, periódicos e artigos encontrados levaram à procura de outras fontes de dados, como catálogos de publicações de instituições internacionais e nacionais relacionadas aos museus e à inclusão social como: ONCE Organização Nacional de Cegos da Espanha, AFB - American Foundation for the Blind EUA, Programa Arte sem Barreiras - FUNARTE Minc, Smithsonian Institute - EUA, AAM - American Association of Museums, Vitae - Brasil (Fundação que atuou no Brasil da década de 1990 à década de 2000, apoiando técnica e financeiramente projetos culturais; nesse ínterim, traduziu publicações sobre museologia e ação cultural da Museums and Galleries Commission do Reino Unido), Tate Modern - Inglaterra (museu que é o exemplo de acessibilidade e inclusão considerado nesta pesquisa) e outros. Nesse percurso foi possível encontrar um maior número e qualidade de registros, mas ainda sem a constituição de uma teoria sobre o assunto.

Para completar a busca foi realizada uma vasta pesquisa na Internet para localizar artigos publicados em anais de congressos, artigos de revistas eletrônicas e impressas, propostas de acessibilidade em museus não publicadas, relatórios, relatos e outros documentos que pudessem conter informações relevantes para a compreensão completa do cenário de ações culturais inclusivas.

Foi realizada leitura e análise de todo material encontrado sobre o tema, no entanto, estão contempladas no texto as referências das publicações mais relevantes e adequadas aos conceitos de ação e mediação cultural e inclusão social, movimentos teóricos e militantes selecionados para nortear a pesquisa. Os dados bibliográficos referentes aos materiais teóricos selecionados para fundamentar a dissertação encontram-se disponíveis no item Referências Bibliográficas.

As fontes de dados utilizadas na pesquisa foram definidas da seguinte forma: os dados secundários internos foram coletados em publicações de museus e instituições culturais e de instituições especializadas em atendimento de pessoas com deficiência ligadas diretamente aos temas de acessibilidade, inclusão e políticas culturais para 
pessoas com deficiência. Os dados secundários externos foram extraídos de publicações teóricas gerais, governamentais, institucionais, teses e dissertações, centros de pesquisa e serviços padronizados de informação dos meios de comunicação (periódicos impressos e internet). Os dados primários foram extraídos dos depoimentos de pessoas com deficiência e gestores culturais, nas análises de casos de museus visitados e estudados em outras fases acadêmicas (Pesquisa/Monografia de Especialização em Museologia "A Inclusão das Pessoas com Deficiência Visual nos Museus: uma análise com base em avaliações sobre acessibilidade" desenvolvida no Curso de Especialização em Museologia do Museu de Arqueologia e Etnologia da Universidade de São Paulo nos anos de 2003 e 2004) e nas visitas técnicas documentadas com imagens e relatórios, realizadas durante o período de elaboração da pesquisa (entre 2006 e 2008).

A fundamentação da situação dos museus em relação às pessoas com deficiência na atualidade deu-se a partir de uma bibliografia que aborda a cultura contemporânea em diferentes aspectos: políticos, sociais e filosóficos. Também foram consultadas obras de literatura contemporânea que tratam de assuntos correlatos à pesquisa como deficiências e os cinco sentidos nas relações humanas. Outra fonte de dados para esta abordagem foi por meio de leitura analítica de notícias, debates e críticas em mídia impressa e virtual.

As fontes de dados selecionados para complementar a fundamentação teórica e conferir caráter interdisciplinar foram:

- Publicações de áreas correlatas ao tema Acessibilidade e Inclusão de Pessoas com Deficiências em Museus;

- Documentos referentes à legislação e políticas em benefício de pessoas com deficiência;

- Análises de casos de programas de acessibilidade em museus com resultados publicados em guias, revistas científicas, livros e anais de eventos disponíveis em formato impresso e/ou digital;

- Sistematização de visitas técnicas em museus, exposições e centros culturais com ofertas de recursos acessíveis em diferentes níveis 
(adequações físicas, leituras sensoriais, programas educativos segmentados, e outros). Para análise completa das experiências, priorizou-se o acompanhamento de pessoas com deficiência para observar a qualidade das propostas. Ofertas culturais ocorridas no período de março de 2006 a março de 2008;

- Registro de depoimentos colhidos através de entrevistas realizadas com gestores culturais sensíveis à inclusão social e pessoas com deficiência e relacionamento estabelecido com instituições culturais.

$\mathrm{Na}$ etapa de definição dos entrevistados em conjunto com o orientador, foram indicados oito convidados para cada lado do sistema consultado. A escolha de pessoas para dar depoimento priorizou a experiência na gestão de museus e equipamentos culturais semelhantes e a aproximação ou simpatia à causa da inclusão cultural; o próprio orientador Martin Grossmann também foi consultado, por desenvolver, em sua gestão, um programa voltado à acessibilidade no Centro Cultural São Paulo e por sua experiência pioneira com o público em questão no Museu de Arte Contemporânea da Universidade de São Paulo. No entanto, no processo de convite e espera de posicionamento destas pessoas, ocorreram algumas dificuldades em colher os depoimentos.

No caso dos gestores culturais, um primeiro grupo comprometeu-se prontamente a participar da pesquisa e progressivamente entregou ou concedeu as respostas; um segundo grupo de respondentes não se posicionou quanto à participação na pesquisa de imediato, o que ocasionou uma segunda chamada para participação com o apoio do orientador. Após essa etapa todos os convidados deram suas contribuições.

No caso do grupo de pessoas com deficiência, também foram definidos oito convidados, duas pessoas com cada tipo de deficiência: visual, auditiva, física e intelectual, seguindo os critérios expostos dois parágrafos acima. Um dos convidados com deficiência auditiva, apesar de enviar uma resposta positiva, não ofereceu sua contribuição efetiva, mesmo com a realização de algumas solicitações. Tentei encontrar 
outra pessoa com a mesma deficiência que pudesse ocupar seu lugar, mas não obtive sucesso.

No convite para a entrevista com duas pessoas com deficiência intelectual, por meio do Ateliê de Arte Terapia do Centro Cultural São Paulo, fui surpreendida por quatro interessados em participar da pesquisa. No entanto, três destes colaboradores não tinham deficiência intelectual e, sim, doenças mentais; nesse caso optei por incluir na análise apenas a entrevista com Cláudio de Jesus, deficiente intelectual.

A coleta dos dados primários referentes aos estudos e análises de casos em visitas presenciais em museus, exposições e instituições culturais e de atendimento especializado foi definida pela oferta de serviços culturais acessíveis a pessoas com deficiência ou de caráter inclusivo por meio do uso de formas de comunicação alternativas. Por conta desse critério, não houve previsão ou definição de uma quantidade de visitas ou de instituições a ser cumprida. Na medida da divulgação de exposições, propostas e convites recebidos foram conferidas presencialmente todas as ofertas possíveis. A maior parte destas visitas foi registrada com imagens e relatórios que não seguem um roteiro pré-definido. A análise desses dados está presente no terceiro capítulo junto à análise crítica das situações vivenciadas pela pesquisadora e pelas pessoas com deficiência presentes em alguns dos casos. 


\section{Quadro Teórico de Referência}

Esta dissertação de mestrado tem como referência teórica uma pesquisa interdisciplinar na qual se destacam as áreas de Inclusão Social, Acessibilidade, Museologia, Ação e Mediação Cultural e Políticas Culturais.

Dentro deste quadro teórico serão abordadas, em primeira instância, questões referentes à Inclusão Social e Acessibilidade, relacionando as mesmas ao contexto cultural dos museus e instituições culturais.

As referências bibliográficas para discussão das questões que permeiam o tema Inclusão Social e Acessibilidade em museus serão fundamentadas em textos de autoria de Romeu Sassaki, Dorina de Gouvêa Nowill, Teixeira Coelho, Laura Gardner \& Gerda Groff e Ricardo Resende. Outros materiais de referência para esta discussão são a Declaração Internacional de Direitos Humanos da ONU - Organização das Nações Unidas, a Classificação Internacional de Funcionalidade da OMS - Organização Mundial de Saúde, o Censo de 2000 realizado pelo IBGE - Instituto Brasileiro de Geografia e Estatística e leis relacionadas aos direitos das pessoas com deficiência e à acessibilidade em equipamentos urbanos, como a ABNT-NBR 9050 - Norma Brasileira de Acessibilidade da Associação Brasileira de Normas Técnicas.

A discussão apontada acima configura o primeiro capítulo deste trabalho que apresenta os dois lados do sistema museus $x$ pessoas com deficiência, esclarecendo as principais diretrizes e definições em relação à deficiência: a acessibilidade, as formas de mediação nos museus, por esta ser uma das principais barreiras de acesso para tal público, e uma análise preliminar em relação às teorias favoráveis à inclusão de pessoas com deficiência nos museus.

A contextualização e discussão em torno do tema da Museologia e suas inclinações em direção à inclusão de pessoas com deficiências terão por referência maior as declarações e cartas que conferem os novos rumos de atuação dos museus, produzidas em encontros e seminários promovidos pelo ICOM - International Council of Museums, a partir da segunda metade do século $\mathrm{XX}$ e os debates em relação à 
linguagem e estratégias de comunicação museológica frente à globalização, regidos por Guy Debord, Ricardo Resende, Marcelo Mattos Araújo, Cristina Bruno e Judite Primo.

Em se tratando de uma pesquisa dirigida ao questionamento em relação à criação de políticas culturais de acessibilidade em museus, foram entrevistados grupos de pessoas com deficiência e gestores culturais que tinham contribuições válidas a oferecer sobre o problema da pesquisa.

Sendo assim, os pressupostos conceituais acima referidos servirão como base para alcançar mais um importante objeto de estudo desta dissertação, que é o das políticas culturais de acessibilidade em museus. Para isso, faz-se necessário discorrer sobre questões atuais da inclusão de pessoas com deficiência em diversas esferas sociais e sobre as propostas de novas abordagens sensoriais e acessíveis nos museus e ofertas culturais.

Foram selecionados textos e publicações que tratam da necessidade de abordagem sensorial nas manifestações culturais, tendo como enfoque a análise de diferentes linguagens como literatura, teatro, cinema e artes. A revisão desses acontecimentos foi realizada na leitura crítica de notícias divulgadas pela mídia impressa e on-line, vinculada à experiência acadêmica e profissional da autora em dez anos de experiência na atuação e coordenação de programas de inclusão em museus e exposições e constante investigação de propostas sensoriais e inclusivas promovidas por diferentes agentes culturais.

Pode-se obter, então, a partir da análise desse quadro teórico, o suporte necessário para analisar mais especificamente o tema a ser desenvolvido - os subsídios práticos e teóricos para políticas culturais inclusivas.

Para que tal tema possa ser então desenvolvido dentro da complexidade e abrangência necessária à viabilidade e aplicabilidade de políticas dessa natureza, novos referenciais foram acrescentados, destacando-se aqueles dirigidos à pesquisa sobre acessibilidade e inclusão em museus.

Dentre esses referenciais foram selecionadas leis e instruções normativas de acessibilidade, como também manuais e guias de acessibilidade nacionais e internacionais. 
Para desenvolver, portanto, o tema relativo ao tema da "Reabilitação do Museu: Políticas de Inclusão Cultural por meio da Acessibilidade" foi necessário estabelecer uma ligação entre este quadro teórico de referência e os casos reais relatados e vivenciados nas visitas técnicas e entrevistas realizadas e sistematizadas pela autora. (relação de visitas disponível no ANEXO 1 e entrevistas na íntegra disponível no ANEXO 3)

Aliando-se, dessa forma, o quadro de referência teórico aos dados primários coletados em diferentes situações, será possível desenvolver subsídios teóricos para políticas culturais inclusivas e acessíveis em museus, pesquisa esta com a intenção de colaborar com propostas reais de políticas congêneres que venham, efetivamente, beneficiar o acesso de pessoas com deficiência ao patrimônio cultural preservado pelos museus e instituições culturais. Os resultados desta pesquisa, enfim, colaboram para a afirmação do museu como agente de desenvolvimento social e demonstram os benefícios dessa ação para a sustentabilidade das instituições culturais na sociedade contemporânea. 
Capítulo 1 - A relação entre os museus e as pessoas com deficiência sob diferentes abordagens.

Este capítulo tem como objetivo apresentar as duas esferas envolvidas no problema desta pesquisa: as pessoas com deficiência e os museus. A ênfase, entretanto, é dada à análise das relações entre a pessoa com deficiência e a cultura institucionalizada, debatendo a acessibilidade, as formas de mediação cultural e a inclusão social.

Partindo do pressuposto de que o museu é um equipamento social deficiente em relação ao acesso à informação para a diversidade de públicos existentes, é possível afirmar que o mesmo precisa se reabilitar, buscando maneiras de aproximação que respeitem as diferentes formas de alcance, comunicação e relacionamento da população, que em número significativo possui alguma deficiência ou dificuldade temporária.

Para que essa reabilitação inicie seu processo, entretanto, é necessário conhecer um dos principais focos do problema que é a estrutura de funcionamento dos museus. No aspecto físico de edifícios, após mais de 20 anos de redação da Norma Brasileira de Acessibilidade, NBR 9050, é possível afirmar que existe legislação e fiscalização das autoridades competentes e da sociedade civil para que as adequações de acessibilidade sejam implantadas. No aspecto de acesso à informação, apesar de existirem referências teóricas favoráveis ao uso dos sentidos nas estratégias de mediação, ainda são raros os casos de projetos e programas que coloquem esse aspecto em prática e que, conseqüentemente, tornem a linguagem dos museus mais acessível a indivíduos com diferentes níveis intelectuais e cognitivos.

Também neste capítulo são apresentadas as discussões acerca dos critérios que estabelecem a condição de deficiência no indivíduo, dado necessário para embasar propostas inclusivas coerentes com os parâmetros sociais vigentes. Esta informação é complementada com a apresentação e reflexões sobre o conceito de acessibilidade e sua aplicabilidade na realidade dos museus. Com base nestes três aspectos, a questão da acessibilidade à cultura é problematizada em seu atual estado de debate sob o 
ponto de vista social, da mediação cultural e da inclusão social, introduzindo as discussões subseqüentes, aprofundadas no segundo capítulo, que analisam a trajetória histórica deste tema e as contribuições que os agentes envolvidos no sistema podem oferecer. 


\subsection{A Mediação Sensorial nos Museus}

Praticar a inclusão nas instituições culturais pressupõe o desenvolvimento de novas estratégias de mediação, nas quais todos os sentidos inerentes à percepção de seus visitantes sejam envolvidos. A linguagem dos museus é regida pela cultura ocidental, em que predomina a exploração visual, o que leva os visitantes a uma relação superficial com o conteúdo das exposições.

A arte se manifestou multissensorial ao longo da história. Desde movimentos estéticos neoclássicos até a arte contemporânea, artistas emblemáticos propuseram experiências sensoriais. A história não é documentada apenas por suas imagens. Os sons, os sabores, os odores e as sensações também são contemplados pelos historiadores e pesquisadores em seus relatos e textos críticos. As ciências estudam fenômenos e formas de vida que não podem ser resumidos ao aspecto visual. As técnicas e tecnologias precisam ser perpetuadas e experimentadas em sua totalidade e não apenas contempladas como criações divinas.

O apelo visual na cultura contemporânea já não possui o caráter de sentido da razão e sabedoria presente no pensamento moderno. O paradoxo da visão e não visão é questionado por filósofos, artistas, cineastas, escritores e outros profissionais criativos que tentam de diferentes formas despertar outros sentidos nas relações culturais e humanas.

Talvez essa 'insensibilidade' na maior parte das vezes inconsciente, seja fruto de vários fatores pertinentes ao mundo contemporâneo, que vivemos regido principalmente pelo sentido da visão. O que temos é uma avassaladora pluralidade de informações visuais, bombardeadas pelos mais diversos tipos de mídia (televisão, cinema, revistas, jornais, outdoors, entre tantos outros) que para pessoas de maior sensibilidade, se tornam uma 'massa' indistinta de forte poluição visual, dificultando a percepção visual de simples elementos visuais do cotidiano. (RESENDE, 2002, Texto curatorial da exposição "Vistas Táteis")

No âmbito patrimonial também é possível identificar alguns motivos para uma nova forma de concepção dos sistemas de informação e da linguagem expográfica. Um deles é a existência de uma pluralidade de bens patrimoniais envolvendo desde objetos 
da cultura material até patrimônio imaterial e intangível. Essas novas categorias de coleção e acervo têm feito com que profissionais e teóricos da área de patrimônio problematizem constantemente os parâmetros e procedimentos de tombamento, conservação e documentação ligada a essa nova condição.

Os caminhos possíveis para preservação e difusão destes diferentes patrimônios podem ser a acessibilidade aos sistemas de informação e as propostas de mediação cultural, já que uma tradição ou indícios de saberes populares só são devidamente preservados na criação de sentido para o indivíduo.

Tomemos como exemplo as receitas tradicionais de alimentos. O que deve ser tombado, o fazer ou o paladar?

Uma receita resulta em um alimento de sabor único que, por sua vez, precisa ser preservado, já que é aquele sabor que informa as influências de uma ou mais culturas na combinação de ingredientes ou no tipo de utensílio utilizado para o preparo. Um autêntico "Baião de Dois" é reconhecido por seu aspecto visual, pelos ingredientes utilizados no preparo ou por seu sabor peculiar?

As exposições dedicadas a hábitos alimentares de uma comunidade ou região, por exemplo, geralmente articulam imagens bidimensionais, objetos expostos em vitrines e textos relacionados ao tema; nesse sentido a proposta de mediação pode ser comparada à leitura de um livro com a mesma temática, a única diferença é o espaço físico.

Outro exemplo favorável para incentivar a mudança de estratégias de mediação são as propostas de imersão em exposições de artistas contemporâneos, museus de ciências e expografias de mostras temáticas que começam a utilizar os recursos tecnológicos com a intenção de transpor as pessoas para situações inusitadas. Essa nova tecnologia pode ser utilizada também em programas museológicos e exposições de coleções permanentes com o intuito de proporcionar experiências sensoriais em relação ao patrimônio. Por exemplo, é possível proporcionar uma experiência de um ritual da religião Candomblé transpondo o visitante de um museu a um terreiro típico, por meio do uso dos sons, odores, iluminação e esfumaçamento do local. Tudo isso 
bem planejado e sincronizado oferece uma experiência de fruição da temática, que por sua natureza é multissensorial.

Mesmo sabendo que nós, seres humanos, percebemos o mundo através de todos os nossos sentidos, as ações culturais permanecem explorando excessivamente a visão, deixando de lado toda a riqueza de relações que podem ser estabelecidas de maneira mais holística e menos racional.

O desenvolvimento do pertencimento cultural, que é um dos principais objetivos dos museus na atualidade, pode ter a mediação sensorial como estratégia lançando mão de recursos olfativos, de apelo ao paladar, sonoros e táteis, além é claro do recorrente apelo visual. A percepção sensorial não pressupõe conhecimentos intelectuais, domínio de linguagem ou idioma e familiaridade com ofertas culturais; ela é livre das barreiras inerentes à origem elitizada e acadêmica dos museus e tem o poder de envolver e cativar toda a diversidade de público dos museus.

A visão é o sentido mais explorado nas exposições e este fato contribui para a formação de uma barreira de comunicação com o visitante que impede a interatividade, uma das principais demandas das pessoas em relação aos museus. É possível observar as pessoas visitando as exposições sem se envolverem com o conteúdo apresentado, como consumidores em frente à vitrine de uma loja, tudo o que vêem parece igual e distante de sua realidade.

O som é um recurso extremamente explorado e vital no cinema, nas telenovelas e até mesmo em mostras temporárias que utilizam abordagens intimistas, já que este recurso envolve o indivíduo para influenciar sua percepção da mensagem. Durante a redação da "Declaração de Caracas", em 1995, no encontro dos membros do ICOM International Council of Museums, conselho que norteia a atuação dos museus e instituições culturais do mundo todo, o debate acerca do som como recurso de mediação já acontecia, como é possível constatar na citação:

Um caso em que a sonorização não constitui uma música ambiente, senão de certo modo, um elemento concreto da exposição: o som, no momento da visita do novo Museu da Bocha em Bayone (França). Uma montagem musical ilustra com precisão e com formas variadas a intervenção da música no desenvolvimento de uma partida de bola - o guia põe em funcionamento o som no momento preciso e à distância. (ARAÚJO E BRUNO apud RIVIÉRE, 1995 p. 14) 
O tato é considerado pelos museus como um vilão, pelos prejuízos à conservação de acervos materiais. Essa afirmação é comprovada por importantes pesquisas, as quais também apontam que alguns materiais apresentam bastante resistência ao manuseio. As conclusões e considerações dessas pesquisas poderiam nortear a criação de programas de acesso tátil às obras e objetos de alta resistência física, como já acontece em museus que seguem políticas públicas ou institucionais de acesso. Na França, por exemplo, a política pública de inclusão cultural, oferece uma licença às pessoas com deficiências visuais de permissão para tocar em todas as obras de arte e monumentos históricos tridimensionais instalados em locais públicos.

\begin{abstract}
A abordagem corpo-a-corpo com uma escultura, por exemplo, me deixa muito feliz, significa olhar não só com minhas mãos, mas com minha presença corporal, e um cego não olha somente com as mãos, mas também com todo o corpo, esta é a diferença. (BAVCAR, 2007, entrevista cedida para esta pesquisa)
\end{abstract}

O olfato ainda aparece de forma tímida, salvo em alguns museus de história natural, para complementar a interação dos visitantes com habitats e ecossistemas distantes e em estratégias de comunicação ligadas a acervos olfativos como museus de essências, perfumes e parques botânicos.

O paladar também é pouco utilizado, a não ser pelas cafeterias anexas que raras vezes oferecem cardápios ligados aos eixos curatoriais dos museus que as abrigam. Esse tipo de ação é mais constante em propostas de ação cultural em formatos mais populares como feiras e festivais. Nesses casos são criados espaços para propostas de mediação que extrapolam o espaço expositivo das instituições culturais. Alguns exemplos: "feiras étnicas", "festivais de cultura popular", "festas das nações", geralmente promovidas por museus históricos e centros culturais ligados às manifestações populares.

Além dos cinco sentidos aqui abordados, ainda possuímos outros pouco conhecidos e explorados, mas essenciais para pessoas que perdem um ou mais sentidos. Como os golfinhos, possuímos a ecolocalização que é a capacidade de identificar a localização de um corpo ou objeto pelo eco de seu som. A percepção 
sinestésica permite decodificar espaços por meio do movimento do vento e da densidade do ar, mesmo em ambientes fechados.

O cotidiano das metrópoles e da dinâmica da vida contemporânea não incentiva as pessoas a desenvolverem os sentidos em sua plenitude; por essa razão podemos considerar que temos deficiências sensoriais, por nossa dificuldade em traduzir conteúdos e conceitos de diferentes linguagens, além da representação visual. $O$ computador - ferramenta e a internet - meio de relacionamento predominante na sociedade, não consegue estabelecer vínculos que não sejam visuais com seus usuários.

Os museus, como agentes de desenvolvimento social, responsabilidade transferida pelo ICOM a estes equipamentos, têm o desafio de cativar visitantes e desenvolver o pertencimento. Para ter sucesso nestas atribuições e se diferenciar dos meios de comunicação em massa precisa quebrar a dinâmica visual dos relacionamentos contemporâneos, fazendo uso de propostas de mediação multissensoriais para estabelecer vínculos sensíveis com seus visitantes, podendo, então, afirmar sua validade na dinâmica social. 


\title{
1.2. As deficiências
}

Como afirma Teixeira Coelho em seu Dicionário Crítico de Políticas Culturais, no verbete relacionado ao público em questão, é necessário conhecer as deficiências em suas especificidades para elaborar propostas de ação e mediação cultural que realmente atendam às necessidades e anseios do público em questão.

A condição de deficiência está ligada a diferentes fatores. Em alguns casos não é a condição física ou psicossocial que define se o indivíduo tem ou não uma deficiência. Na abordagem atual defendida pela Organização Mundial de Saúde, a deficiência está atrelada a uma classificação, a CIF - Classificação Internacional de Funcionalidade, que leva em consideração, com igual importância, o aspecto ambiental, isto é, as barreiras sociais enfrentadas pelos indivíduos.

Com base na CIF, o movimento de Inclusão Social desenvolve teorias e conceitos que acreditam em uma sociedade livre de barreiras físicas, sociais e comunicativas para que a pessoa, independente de sua condição física, sensorial e intelectual, possa viver plenamente em todos os ambientes e ter oportunidades iguais aos demais indivíduos.

\begin{abstract}
A CIF é baseada, portanto, numa abordagem biopsicossocial que incorpora os componentes de saúde nos níveis corporais e sociais. Assim, na avaliação de uma pessoa com deficiência, esse modelo destaca-se do biomédico, baseado no diagnóstico etiológico da disfunção, evoluindo para um modelo que incorpora as três dimensões: a biomédica, a psicológica (dimensão individual) e a social. Nesse modelo cada nível age sobre e sofre a ação dos demais, sendo todos influenciados pelos fatores ambientais. (BUCHALLA e FARIAS, 2005 p.189)
\end{abstract}

A CIF proporciona a análise qualificada sobre as ações da sociedade em relação à pessoa com deficiência alertando que:

Os conceitos apresentados na classificação introduzem um novo paradigma para pensar e trabalhar a deficiência e a incapacidade: elas não são apenas uma conseqüência das condições de saúde/doença, mas são determinadas também pelo contexto do meio ambiente físico e social, pelas diferentes percepções culturais e atitudes em relação à deficiência, pela disponibilidade de serviços e de legislação. Dessa forma, a classificação não constitui apenas um instrumento para medir o estado funcional dos indivíduos. Além disso, ela 
permite avaliar as condições de vida e fornecer subsídios para políticas de inclusão social. (BUCHALLA e FARIAS, 2005 p. 190)

Seguindo a conduta de relacionamento com a deficiência proposta pela CIF, que busca desenvolver programas qualificados de inclusão sob os aspectos culturais, sociais e ambientais, estabelecem-se as bases conceituais desta pesquisa com a finalidade de fornecer subsídios válidos para políticas culturais de inclusão em museus que evitem as barreiras de acesso no ambiente cultural.

Atualmente são classificadas pessoas com deficiência os indivíduos que: possuem algum tipo de limitação física (membros superiores, inferiores, paralisias cerebrais, em partes do corpo e deficiência de crescimento), intelectual (síndromes e déficits devido a acidentes ou má formação) e sensorial (visual e auditiva) em diferentes gradações que podem variar de comprometimentos leves, médios, graves até a perda total da capacidade. Por exemplo, o termo 'cego' define o indivíduo que perdeu totalmente a capacidade de enxergar, enquanto o termo deficiente visual pode representar um indivíduo com perdas visuais de leve a grave, bem como o termo deficiente auditivo representa um indivíduo com baixa-audição. As deficiências também podem ocorrer simultaneamente com um mesmo indivíduo, o que é denominada deficiência múltipla; um exemplo desse caso são os deficientes de áudio-visão (surdocegos).

As pessoas com mobilidade reduzida: idosos, gestantes, obesos, amputados, fraturados são incluídas do escopo da CIF, como indivíduos que sofrem exclusão do meio social pelas dificuldades de acesso, principalmente físico, aos equipamentos e atividades.

A seguir estão definidos os tipos de deficiência segundo o decreto 3.298, de 20 de dezembro de 1999, Portaria №298, de 9 de agosto de 2001, que estabelece que "deficiência permanente é aquela que ocorreu e se estabilizou durante um período de tempo suficiente a não permitir recuperação ou ter probabilidade de que se altere, apesar de novos tratamentos":

Deficiência Física: "Alteração completa ou parcial de um ou mais segmentos do corpo humano, acarretando o comprometimento da função física". 
A Declaração dos Direitos das Pessoas Deficientes elaborada pela Assembléia Geral das Nações Unidas em 1975 definiu o deficiente físico como uma pessoa incapaz de assegurar, por si mesma, total ou parcialmente, as necessidades de uma vida individual ou social normal, em decorrência de uma deficiência, congênita ou não, em suas capacidades físicas. Mas esse conceito está ultrapassado, por não enfocar as aptidões que o portador de deficiência também possui. São considerados portadores de deficiência física os indivíduos que apresentam problemas ortopédicos que incidam sobre a possibilidade de motricidade voluntária, impedindo-os total ou parcialmente, dentro de padrões considerados normais para a espécie humana. A deficiência física pode ser chamada de deficiência mecânica ou motora. As mutilações e as seqüelas motoras (sejam de causas ligadas a moléstias ou acidentes) podem ser subdivididas de acordo com os sistemas orgânicos de origem que foram afetados:

- De origem encefálica: neste grupo incluímos a esclerose múltipla, o AVC e a Paralisia Cerebral;

- De origem espinhal: neste grupo estão incluídas poliomielite, traumatismos com ruptura ou compressão medular, má-formação, como espinha bífida, por degeneração, como a Síndrome de Werdnig-Hoffmann, etc;

- De origem muscular: especialmente a distrofia muscular progressiva (ou miopatia);

- De origem ósteo-articular: são aqui incluídas a luxação coxo-femural, artrogripose (contração permanente da articulação) múltipla, ausência congênita de membros ou partes de, formas distróficas como osteocondriosis (coxa plana), osteogenesis imperfecta (doença que fragiliza o tecido ósseo, sendo popularmente chamada de "ossos de vidro"), condodistrofia, amputações, entre outras.

Deficiência Auditiva: "Perda parcial ou total das possibilidades auditivas sonoras, variando em graus e níveis". 
Segundo o decreto 3.298, de 20 de dezembro de 1999, a deficiência auditiva é uma "perda parcial ou total das possibilidades auditivas sonoras, variando em graus e níveis". Há diferentes tipos de perda auditiva. São chamados de 'surdos' os indivíduos que têm perda total ou parcial, congênita ou adquirida, da capacidade de compreender a fala através do ouvido. Com base no trabalho de Roeser \& Downs, Martinez (2000), é possível classificar a pessoa com deficiência de acordo com seu grau de perda auditiva, avaliada em decibéis.

A audição está normal quando há uma diminuição de até $15 \mathrm{~dB}$; nos casos de perda entre 16 e $25 \mathrm{~dB}$, há uma deficiência auditiva suave. A surdez manifesta-se como leve quando a perda varia de 26 a $40 \mathrm{~dB}$, moderada entre 41 e $55 \mathrm{~dB}$, moderadamente severa entre 56 e $70 \mathrm{~dB}$ e severa entre 70 e $90 \mathrm{~dB}$.

Quando a perda é maior, existe uma deficiência auditiva profunda que impede o indivíduo de ouvir a voz humana e adquirir, espontaneamente, o código da modalidade oral da língua, mesmo com o uso de prótese auditiva. Pelo menos uma em cada mil crianças nasce profundamente surda, o que é diagnosticado através de exames como a audiometria e o audiograma. Muitas pessoas desenvolvem problemas auditivos ao longo da vida devido a acidentes ou doenças.

Deficiência Visual: "Acuidade visual igual ou menor que 20/200 no melhor olho, após a melhor correção, campo visual inferior a 20, ou ocorrência simultânea de ambas as situações".

Segundo a American Foundation for the Blind (1961), a definição de deficiência visual é quantitativa. É considerada 'cegueira' a acuidade visual de 6/60 ou menos no melhor olho com correção apropriada e uma restrição do campo visual menor que 20 graus, caracterizando a "visão de túnel" (6/60 significa que a pessoa precisa de uma distância de seis metros para ler o que normalmente se leria a sessenta metros). 
Uma pessoa com baixa visão é aquela que possui seu funcionamento visual comprometido, mesmo após tratamento e/ou correção de erros refracionais comuns. Ela tem acuidade visual inferior a 10 graus de seu ponto de fixação (20/200 a 20/70 pés no melhor olho após correção máxima), mas, apesar disso, utiliza ou é possivelmente capaz de utilizar a visão para o planejamento e a execução de uma tarefa (Informações da Sociedade Brasileira de Visão Subnormal).

Deficiência Intelectual: "Funcionamento intelectual geral significativamente abaixo da média, oriundo do período de desenvolvimento, concomitante com limitações associadas a duas ou mais áreas da conduta adaptativa ou da capacidade do indivíduo em responder adequadamente às demandas da sociedade".

Segundo a definição adotada pela AAMR (American Association of Mental Retardation - Associação Americana de Deficiência Mental) a deficiência mental é um "funcionamento intelectual significativamente abaixo da média, coexistindo com limitações relativas a duas ou mais das seguintes áreas de habilidades adaptativas: comunicação, auto-cuidado, habilidades sociais, participação familiar e comunitária, autonomia, saúde e segurança, funcionalidade acadêmica, de lazer e trabalho. Manifesta-se antes dos dezoito anos de idade".

Devemos enfatizar que a pessoa com deficiência intelectual não tem alterada a percepção de si mesma e da realidade, e é, portanto, capaz de decidir o que é melhor para ela. Quando a percepção encontra-se alterada, a condição é denominada doença mental, tratando-se de um quadro totalmente diferente da deficiência intelectual, apesar do fato de que 20 a $30 \%$ dos deficientes intelectuais apresentem associação com algum tipo de doença mental, como a síndrome do pânico, depressão, esquizofrenia, entre outras. Doenças mentais, que podem e devem ser tratadas, afetam o desempenho dos indivíduos, pois prejudicam, primariamente, outras áreas do funcionamento, que não a inteligência, como, por exemplo, a capacidade de concentração e o humor. 
Deficiência Múltipla: É a associação, no mesmo indivíduo, de duas ou mais deficiências primárias (mental/visual/auditiva/física), com comprometimentos que acarretam conseqüências no seu desenvolvimento global e na sua capacidade adaptativa.

As pessoas com deficiência múltipla são aquelas afetadas em duas ou mais áreas, caracterizando uma associação entre diferentes deficiências, com possibilidades bastante amplas de combinações. Dois exemplos seriam os surdo-cegos e as pessoas com deficiência mental e física ao mesmo tempo. ${ }^{1}$

As estatísticas da OMS (Organização Mundial de Saúde) estimam que 10\% da população mundial apresentam algum tipo de deficiência. No Brasil, segundo o último censo realizado em 2000 pelo IBGE, 14,5\% da população têm alguma deficiência, o que corresponde a aproximadamente 25 milhões de pessoas. As estatísticas, no entanto, ainda não quantificam as pessoas com mobilidade reduzida, o que aumenta o número de indivíduos com restrições de acesso a diversas esferas sociais, impedidas, do pleno exercício da cidadania.

Respeitando as diretrizes e conceitos conquistados pelo Movimento de Inclusão Social internacional, este trabalho utiliza o termo 'pessoas com deficiência'. É possível, no entanto, encontrar em citações alguns termos ultrapassados que são: Portadores de Deficiências, Pessoas Especiais (de onde surgiu o termo Público Especial), Pessoas com Necessidades Especiais (de onde surgiu a expressão Alunos com Necessidades Educacionais Especiais).

Todas as definições aqui apresentadas têm o objetivo de esclarecer ao leitor os tipos de deficiência mais comuns. No entanto, vale lembrar que, segundo a CIF norteadora da abordagem em relação à pessoa com deficiência desta pesquisa - a

${ }^{1}$ Extraído de: Rede Saci www.saci.org.br (acessado em 12/06/2007) 
condição de deficiência é ligada a fatores sociais e ambientais; o que quer dizer que, em uma sociedade ideal, livre de barreiras físicas, sociais e comunicativas, pessoas com deficiência podem deixar de apresentar impedimentos no convívio social pleno, se beneficiando de todos os serviços livremente como os demais cidadãos. 


\subsection{Acessibilidade nos museus}

A acessibilidade é uma forma de concepção de ambientes que considera o uso de todos os indivíduos independente de suas limitações físicas e sensoriais, desenvolvida a partir dos conceitos do movimento de Inclusão Social. O conceito influencia os avanços da CIF em relação à melhoria da qualidade de vida da população.

Segundo a ABNT- NBR 9050 - Norma Brasileira de Acessibilidade da Associação Brasileira de Normas Técnicas, acessibilidade é a possibilidade e condição de alcance, percepção e entendimento para a utilização com segurança e autonomia de edificações, espaço, mobiliário, equipamento urbano e elementos.

Seguindo os parâmetros da norma citada, acessível é o espaço, edificação, mobiliário, equipamento urbano ou elemento que possa ser alcançado, acionado, utilizado e vivenciado por qualquer pessoa, inclusive aquelas com mobilidade reduzida. O termo acessível implica acessibilidade física, intelectual, cognitiva e atitudinal.

Portanto, acessibilidade em museus significa que as exposições, espaços de convivência, serviços de informação, programas de formação e todos os demais serviços básicos e especiais oferecidos pelos equipamentos culturais devem estar ao alcance de todos os indivíduos, perceptíveis a todas as formas de comunicação e com sua utilização de forma clara, permitindo a autonomia dos usuários. Os museus para serem acessíveis, portanto, precisam que seus serviços estejam adequados para serem alcançados, acionados, utilizados e vivenciados por qualquer pessoa, independente de sua condição física ou comunicacional.

Apesar de serem quase inexistentes os casos de museus que realmente sejam acessíveis segundo tal definição, podemos citar como um caso de excelência alguns museus da Inglaterra como British Museum, Victoria and Albert Museum, mas principalmente a Tate Modern em Londres. Este museu possui programas voltados a diferentes públicos com o objetivo de acolher a diversidade em seu espaço. Além da acessibilidade física, a Tate Modern desenvolve estratégias de mediação para pessoas com deficiências visuais e auditivas, privilegiando a autonomia do visitante. Para pessoas com deficiências visuais, por exemplo, existem roteiros dentro do espaço 
convencional da exposição, com esculturas acessíveis ao tato, além de espaços de descanso e interação com equipamentos de informação e registro acessíveis a diferentes formas de percepção. Para as pessoas com deficiência auditiva, além de guias digitais disponíveis em palmtops com vídeos em língua de sinais, o museu oferece um curso de arte em língua de sinais, com o objetivo de formar educadores que possam atuar como tutores surdos da coleção. Para pessoas com deficiência intelectual o museu oferece visitas educativas, publicações e guias impressos e auditivos em uma linguagem acessível, desligada de conceitos herméticos e termos intelectualizados. Além dos serviços oferecidos para pessoas com deficiência, a Tate Modern também desenvolve programas em que o público se torna protagonista de mudanças efetivas na conduta da instituição por meio da participação em fóruns de discussão e debates sobre as políticas internas abertos a comunidade. Outra possibilidade oferecida presencial e virtualmente (por meio do site do museu) com o caráter de formação de público em diferentes níveis são os cursos de história e crítica de arte que possibilitam desde extensão e conhecimentos gerais na área até especializações e pós-graduações. Vale também lembrar que o site do museu é acessível, segundo as normas estabelecidas para sítios eletrônicos, e disponibiliza visitas virtuais e acesso a publicações para diferentes públicos. ${ }^{2}$

Além do caso citado na Inglaterra, fruto de uma política pública de acesso às instituições culturais contida no DDA - Disability Discrimination Act, legislação inglesa de garantia de respeito e acesso para pessoas com deficiência -, há em outros países estrangeiros, como Espanha, França, EUA e Austrália, políticas públicas congêneres que incentivam os museus a desenvolverem programas inclusivos e os cidadãos a exigirem seus direitos culturais. Dentro das atribuições das políticas de acesso está a transferência de subsídios para museus, centros culturais, monumentos públicos e

\footnotetext{
${ }^{2}$ Livre adaptação da palestra de Comunidade e Acessibilidade, proferida por Toby Jackson, ex- Diretor de Educação da Tate Modern, ocorrida no Ciclo de Palestras "Educação e Arte: uma experiência da Tate Modern”, na Pinacoteca do Estado de São Paulo, no ano de 2005. Texto completo disponível em: http://forumpermanente.incubadora.fapesp.br/portal/.event_pres/jornadas/educ_toby/documentacao/comun_acessib/ ?searchterm=toby\%20jackson
} 
outros espaços destinados à cultura para que estes desenvolvam recursos físicos de adequação da linguagem expográfica e de mediação específicos para pessoas com deficiência física, intelectual e sensorial.

No Brasil, apesar da existência de legislações e normas técnicas para áreas como edificações, transporte público, educação, saúde e trabalho, até este momento não existe uma política pública para o acesso de pessoas com deficiência às instituições culturais; o único documento encontrado sobre este tema é a Instrução Normativa no. 1, de 25 de novembro de 2003, que dispõe sobre a acessibilidade aos bens culturais imóveis acautelados em nível federal, e outras categorias, conforme especifica - redigida pelo IPHAN - Instituto Nacional do Patrimônio Histórico e Artístico Nacional. Apesar da existência do documento e de sua disponibilidade no sítio eletrônico do órgão em questão, não existem registros, publicações, relatórios ou mesmo evidências consolidadas das ações já realizadas que seguem esta normativa. Constatam-se apenas casos isolados de museus pertencentes ao sistema federal, como o Museu Histórico Nacional do Rio de Janeiro, em que implantaram adequações físicas, seguindo os conceitos de acessibilidade da NBR 9050, possíveis por meio de projetos patrocinados por iniciativa privada.

Mesmo com a inexistência de políticas culturais de acesso aos museus e ao patrimônio, algumas instituições brasileiras, superando as situações adversas do ambiente cultural, desenvolveram por conta própria programas inclusivos; a maioria dos casos ainda não chegou a configurar departamentos ou divisões permanentes destinados à acessibilidade e à inclusão, como já acontece nos países anteriormente citados, ações de longo prazo ou integração na missão destes estabelecimentos. Como exemplo desta afirmação é possível relacionar em particular na cidade de São Paulo: Pinacoteca do Estado de São Paulo - Programa Educativo para Públicos Especiais (em operação); Museu de Arte Contemporânea da Universidade de São Paulo - Programa Museu de Arte e Público Especial (extinto); Museu de Zoologia da Universidade de São Paulo - Projeto para Deficientes Visuais (em operação), ECCO - Espaço Cultural Contemporâneo de Brasília - Programa Educativo Inclusivo (em operação), Museu de Ciências Morfológicas da Universidade Federal de Minas Gerais - Programa A Célula 
ao Alcance das Mãos (em operação) e Museu de Arte Moderna de São Paulo Programa Igual Diferente (em operação).

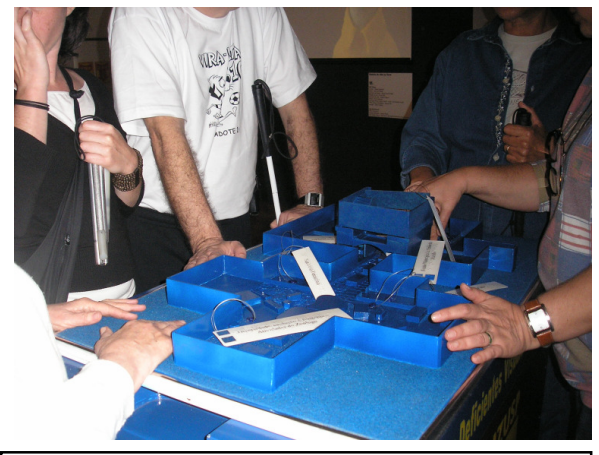

Figura 1. Projeto de Ação Educativa para Deficientes Visuais, Museu de Zoologia da USP, 2006.

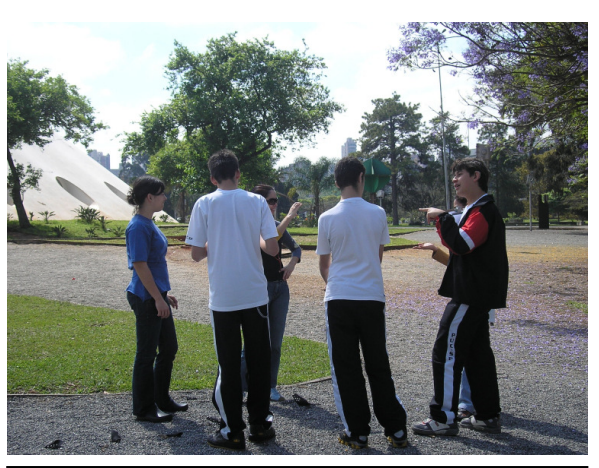

Figura 2. Programa Igual Diferente, MAM SP, 2006

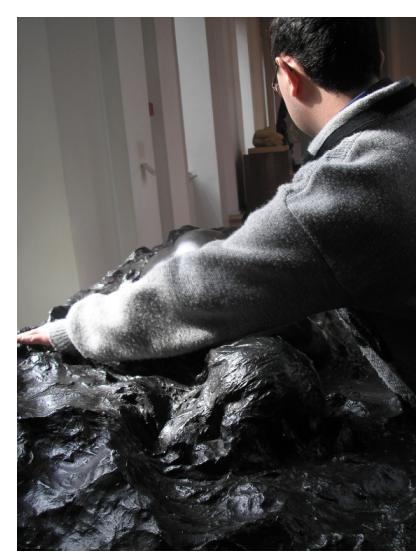

Figura 3. PEPE- Programa Educativo para Público Especial, Pinacoteca do Estado de São Paulo, 2006.

Considerando que o número de museus no Brasil é superior a duas mil unidades, segundo o Cadastro Nacional dos Museus do IPHAN - Instituto do Patrimônio Histórico e Artístico Nacional, realizado no ano de 2006, é possível afirmar que a oferta de acessibilidade em museus do país é quase insignificante, não chegando a $1 \%$ dos estabelecimentos. Essa realidade afasta a população de pessoas com deficiência e mobilidade reduzida das instituições culturais, pois para a maior parte das pessoas com deficiência a eliminação de barreiras arquitetônicas, comunicacionais e intelectuais é imprescindível para o uso dos serviços.

O que ocorre é que uma pequena parcela desta população que possui maior facilidade financeira e física de acesso, situada em cidades e estados mais desenvolvidos econômica e culturalmente, torna-se público assíduo da reduzida oferta que geralmente ocorre nas regiões mais favorecidas culturalmente, deixando de lado suas preferências e gostos pessoais para poder capturar as oportunidades existentes.

Mesmo com os números reduzidos é possível afirmar que, desde a década de 1980, a acessibilidade vem ganhando gradativamente mais espaço na agenda dos museus e instituições culturais. No âmbito institucional, a melhoria é evidente: nas duas primeiras décadas deste período, as ações qualificadas de inclusão cultural não 
ultrapassaram duas instituições; entre elas figura o Museu de Arte Contemporânea da Universidade de São Paulo, que iniciou sua atuação durante a gestão de Aracy Amaral quando foi inaugurado o serviço educativo do museu, no desafio de desenvolver uma ação que incluísse as pessoas com deficiência visual (o relato completo dessa experiência pode ser encontrado na íntegra da entrevista com Martin Grossmann no ANEXO 3 desta dissertação); o extinto Museu da Indústria, Comércio e Tecnologia do Estado de São Paulo, então sob gestão de Waldisa Rússio, que ofereceu exposições, seminários e intercâmbios com as comunidades e instituições de pessoas com deficiência, projeto iniciado a partir do descobrimento da inclusão das pessoas com deficiência nas indústrias paulistas.

No ambiente acadêmico, o espaço para projetos de pesquisa acerca do tema foi iniciado de fato na década de 1990, em poucos departamentos que consideravam essa discussão válida para seus programas: os Departamentos de Ciências da Comunicação (em 2006 esse departamento foi desmembrado e hoje as pesquisas congêneres acontecem no Departamento de Ciência da Informação) e o de Artes Plásticas da Universidade de São Paulo foram os pioneiros nesse sentido, abrindo oportunidades para mestrandos e, na década posterior (2000), para doutorandos. A partir da década de 2000 surgiram novas oportunidades em nível de especialização (Latu Sensu), com o Curso de Especialização em Museologia oferecido pelo Museu de Arqueologia e Etnologia da Universidade de São Paulo (de 1999 a 2006) e, desde 2006, o Programa de Pós Graduação em Museologia da UNIRIO (Strictu Sensu). Nessas duas instituições as iniciativas são tímidas, bem como nos demais departamentos citados; ao todo os especialistas, mestres e doutores que destinaram suas pesquisas a esse tema não chegam a uma dezena. Os cursos não oferecem disciplinas que aprofundem o debate em relação à acessibilidade e inclusão social nos museus; em alguns casos são incluídos seminários temáticos no programa de aula que dão conta somente de um panorama sobre o tema. Antes desse período, durante a década de 1980, podemos considerar como embrionária a atuação de Waldisa Rússio no Curso de Museologia da FESP - Fundação Escola de Sociologia e Política do Estado de São Paulo. Nessa iniciativa, os alunos do curso foram convidados a participar das ações teóricas e 
práticas ligadas às exposições do Museu da Indústria Comércio e Tecnologia que trataram da inclusão na indústria, gerando conscientização e conhecimento em relação às necessidades das pessoas com deficiência.

Em outros ambientes de fomento ao intercâmbio de idéias na área de cultura, o espaço ainda é bastante restrito, mas existem algumas iniciativas pioneiras, como a do site "Fórum Permanente Museus de Arte: entre o público e o privado", que publica artigos, notícias e discussões em relação à problemática, e a do site RINAM - Rede de Informação de Acessibilidade em Museus (recém-criada pela autora desta pesquisa) tendo o projeto anterior como exemplo de animação de rede, mas com ênfase na acessibilidade em museus e espaços culturais e na inclusão do público alvo na rede de colaboradores.

O desenvolvimento desta temática, como acima exposto, tem ocorrido em diferentes ambientes, dentro das possibilidades existentes, com muita persistência de poucos pesquisadores e simpatizantes da causa. Analisando as informações apresentadas é possível verificar que a acessibilidade cultural é uma área com potencial significativo e que pode trazer inovações para a linguagem e formas de mediação cultural praticados pelos museus. No entanto, para que o desenvolvimento dessa área seja possível, é necessário que instituições, órgãos culturais e de classe, universidades e espaços de discussão e debate ofereçam mais oportunidades e se envolvam mais com as lutas e conquistas alcançadas; quanto mais pessoas e forças políticas forem envolvidas, melhor e mais qualificado será o crescimento dos estudos e ações da acessibilidade nos museus. 


\title{
1.4. A Inclusão das Pessoas com Deficiência nos Museus
}

O desenvolvimento da acessibilidade em museus passa por uma questão delicada que é a inclusão das pessoas com deficiência no ambiente cultural.

A inclusão dessa população na sociedade em geral pode ser considerada um acontecimento recente. O próprio termo 'inclusão' começou a ser utilizado e defendido na década de 1980, durante a criação do Movimento de Inclusão Social, nos EUA, com a participação de representantes do mundo todo, da ONU e da UNESCO em 1981, considerado então o "Ano da Pessoa com Deficiência". Antes data citada, o termo utilizado para definir a aproximação dessa população com a sociedade era "integração". No conceito de integração a maior responsabilidade era atribuída ao desenvolvimento pessoal e superação de barreiras do indivíduo, enquanto a sociedade incumbia-se de aceitar ou não a pessoa para o convívio, como um favor ou ato de caridade.

\begin{abstract}
A sociedade, em todas as culturas, atravessou diversas fases no que se refere às praticas sociais. Ela começou praticando a exclusão social de pessoas que por causa das condições atípicas - não the pareciam pertencer à maioria da população. Em seguida, desenvolveu o atendimento segregado dentro de instituições, passou para a prática da integração social e recentemente adotou a filosofia da inclusão social para modificar os sistemas sociais gerais. (SASSAKI, 1997 p.16).
\end{abstract}

Atualmente presenciamos o movimento de Inclusão Social, que trouxe muitas melhorias a esse quadro ao desenvolver ações que visam preparar os ambientes para acolher a pessoa com deficiência, sem discriminação, respeitando suas necessidades e potencialidades, proporcionando oportunidades equivalentes para todos os indivíduos.

Do outro lado do problema, as principais mudanças ocorridas no conceito de ação cultural em museus, tiveram seu início com os manifestos e movimentos ligados à inclusão dos indivíduos no ambiente sacralizado da cultura erudita a partir da segunda metade do século XX. Em um primeiro momento, as manifestações estudantis e de pensadores da área tiveram como objetivo desmitificar a subserviência dos lugares de cultura e patrimônio em relação às classes economicamente dominantes. Esse vínculo foi estabelecido durante a criação dos primeiros museus, frutos de coleções reais, 
eclesiásticas, de nobres e burgueses que, por sua natureza, dependiam financeiramente dessas origens.

Seguindo os conceitos das revoluções culturais, os membros do ICOM, ainda que de forma orgânica, chegaram à conclusão de que os museus deveriam ter como objetivo o desenvolvimento de sua função educativa, para estabelecer elos com os mais diversos públicos, prioritariamente com os jovens e crianças. A partir desse pensamento foi possível transformar equipamentos culturais em pontes entre a informação e os indivíduos. Com essa função os museus desenvolveram estratégias de captação de público, levando em consideração a quantidade acima da qualidade.

A partir da década de 1970, a qualidade na atração dos públicos ganhou espaço nas propostas de políticas institucionais e ações educativas, o que proporcionou o status de equipamento fundamental para o desenvolvimento social e humano. No entanto, os conceitos de inclusão de indivíduos praticados na esfera cultural ainda não consideram toda a diversidade humana e as diferenças físicas, sensoriais e intelectuais da população, deixando de acolher um grande número de pessoas, que supera $10 \%$ dos indivíduos de todo o mundo.

Além do alto percentual de pessoas com deficiência, a estimativa de vida da população mundial é crescente; no entanto, a maior longevidade traz consigo problemas de saúde física e mental que causam dificuldades de locomoção, visão, audição e percepção intelectual. A população de terceira-idade é atualmente uma parcela significativa do público dos museus por uma série de incentivos governamentais e não governamentais como programas de lazer, propostas de voluntariado e subsídios financeiros de incentivo ao turismo, pois essa população é economicamente ativa. Também devemos considerar que em nosso futuro, independente de nossas capacidades físicas, não desejamos perder o direito de ter acesso à cultura.

\footnotetext{
A preocupação com o 'público especial' (sic) é bastante recente nos países da Europa e da América do Norte, e quase inexistente no Brasil. Ela deriva da convicção de que a verdadeira inserção na sociedade só pode se dar e a cidadania plena só pode ser exercida se o sujeito tiver acesso ao patrimônio cultural, por meio do qual lhe é permitido construir sua própria identidade. O 'público especial' (sic) apresenta uma série de deficiências muito diferentes entre si que, para serem atendidas adequadamente, devem ser conhecidas em
} 
suas especificidades. É necessário, para que a comunicação com esse público seja efetiva, ter melhor compreensão das necessidades, modos de aprendizado e determinar se os programas educativos e de ação cultural são eficazes e apropriados ou devem ser modificados. Não se pode esquecer, também, que as deficiências físicas alcançam o público de terceira idade, que se constitui, hoje, em uma parte em crescimento do público de cultura. (COELHO, 1997 p. 328)

A ação e a mediação cultural, seguindo o curso natural de seus movimentos antecessores, têm como desafio desenvolver estratégias de aproximação e inclusão de toda esta complexidade de público nos museus; para tanto, deve servir-se, sobretudo, dos conceitos discutidos pelo movimento de Inclusão Social desde a década de 1980, já que esses desenvolvem teorias de melhoria de qualidade de vida da população, equiparação de oportunidades e mudança da sociedade para eliminação de barreiras de convívio. Observando que:

\begin{abstract}
... Para garantir que tais políticas sociais e leis sejam formuladas adequadamente, ou seja, à luz do que exista de melhor na filosofia da plena participação social, um dos conceitos mais importantes da década de 80 foi o de que 'as pessoas portadoras de deficiência' (sic) e/ou suas organizações nos níveis local, nacional, regional e internacional, devem ser incluídas no processo decisório em todas as etapas de planejamento, 'implementação' (sic), monitoramento (supervisão) e avaliação de políticas e programas de atendimento à pessoa deficiente. (SASSAKI, 1997 p.151).
\end{abstract}

Com base nas evidências estatísticas, sociais e culturais exemplificadas é possível afirmar que políticas culturais de acesso e inclusão de pessoas com deficiência são uma necessidade latente, mas, para que a inclusão seja devidamente exercitada nos museus por meio da acessibilidade, é necessário partir do pressuposto de que existem diferentes sentidos, formas de percepção, necessidades de adequação espacial, formas de comunicação alternativas, níveis de cognição e muitos outros aspectos. Com os parâmetros acima citados é possível estabelecer uma relação de respeito aos direitos culturais das pessoas com deficiência, que durante séculos foi desconsiderado.

Garantir estes direitos por meio da acessibilidade traz benefícios não apenas às pessoas com deficiência, mas também a toda diversidade de públicos do museu que 
deseja freqüentar seus estabelecimentos, independente de suas condições permanentes ou temporárias.

\begin{abstract}
Além do mais, os profissionais de museus sabem que, em último caso, estruturas e programas acessíveis tornam o museu mais visível para um número maior de visitantes potenciais. Rampas para pessoas em cadeiras de rodas também são convenientes para carrinhos de bebê. Sinalização e identificação em caracteres grandes facilitam a leitura de todos. (GARDNER e GROFF, 1990 p. 16. trad. Nossa)
\end{abstract}

No entanto, é necessário atentar para o fato de que a acessibilidade não se restringe a garantir o direito de ir e vir, mas também de ser acolhido, permanecer, participar e voltar ao museu, sem depender de atendimento especial que contribui com a discriminação. Uma instituição cultural que realmente tenha o desejo de ser acessível deve garantir a autonomia do indivíduo em todos seus serviços, sejam eles básicos (banheiros, bebedouros, cafeterias), permanentes (circulação no edifício, exposições permanentes, bibliotecas) temporários (exposições, projetos, novas ocupações) e especiais (cursos, eventos).

Conforme consta no item I do artigo 27 da Declaração Internacional de Direitos Humanos redigida pela ONU - Organização das Nações Unidas, há mais de 50 anos:

"... toda pessoa tem o direito de tomar parte livremente na vida cultural da comunidade, de fruir as artes e de participar no progresso científico e nos benefícios que deste resultam". (ONU, 1948)

Apesar das justificativas em relação às enormes dificuldades de natureza estrutural, burocrática e financeira dos museus, os direitos humanos e culturais estão acima de qualquer problema. Com sensibilidade e participação do público beneficiário das ações, é possível promover acessibilidade sem que os custos sejam altos e as mudanças físicas radicais; levar em consideração as concepções existentes a partir de uma nova dinâmica beneficia, no mínimo, os próprios colaboradores da instituição (o que geralmente só é sentido quando qualquer funcionário, seja faxineiro ou diretor, quebra um membro, fica com seqüelas de doenças cardiovasculares, leva ao museu 
um parente com condições similares, ou recebe uma visita importante de uma pessoa que não tem condições físicas ditas "normais"). 
Capítulo 2 - Análise histórica do processo de acessibilidade em museus: uma revisão dos movimentos das pessoas com deficiência e das diretrizes museológicas estabelecidas pelo ICOM - International Council of Museums

Este capítulo analisa as principais alterações na função dos museus ao longo da segunda metade do século XX que possibilitaram a abertura dos mesmos para novos públicos e objetivos, com a finalidade de afirmarem sua validade diante da globalização. As mudanças ocorreram a partir das discussões e novas situações que levaram os museus a refletirem sobre sua postura diante da sociedade. A principal mudança, ainda em processo de debate, aceitação e realização, foi em relação à finalidade dos museus, que deixou de ser a preservação de coleções para se dedicar ao desenvolvimento social e humano. Com essa atribuição, os museus ganharam novas responsabilidades, como por exemplo, a de acolher públicos não previstos em sua origem histórica, entre estes as pessoas com deficiência.

No âmbito dos direitos das pessoas com deficiência, desde o surgimento dos primeiros movimentos na década de 1960, foram realizadas ações afirmativas de acesso físico e conceitual para essa população em diversos segmentos da sociedade. O contexto de criação de tais movimentos no pós-guerra do Vietnã, nos EUA, tinha como propósito redimir o governo americano pelos danos físicos e psicológicos causados aos soldados recrutados; progressivamente o movimento espalhou-se pelo mundo por meio dos representantes das nações que freqüentavam as reuniões da ONU e UNESCO, sendo que em cada região foi impulsionado por diferentes razões, mas com o mesmo fundamento de equiparação de oportunidades e convívio social. Os benefícios conquistados pelos movimentos de Inclusão Social também deram espaço para a atuação de outras parcelas da população socialmente excluídas, como homossexuais, soropositivos e pessoas contaminadas com o vírus HIV, afrodescendentes e imigrantes.

As adequações de acessibilidade representam atualmente os principais desafios a serem desenvolvidos pelos equipamentos culturais brasileiros, pelo risco de se tornarem insustentáveis em uma dinâmica social de respeito e celebração das 
diferenças, contribuindo com a inclusão cultural e com a eliminação de barreiras de convívio.

A luta do movimento de Inclusão Social tem sido alavancada pelo espaço que a mídia oferece para sensibilização e conscientização da sociedade e também pela atuação de autoridades governamentais na criação de leis e normativas que impulsionem as oportunidades equivalentes às pessoas com deficiência em diferentes esferas sociais. As grandes corporações que ditam as regras do mercado brasileiro também seguem a tendência da 'Responsabilidade Social', mostrando-se favoráveis à inclusão em seus programas de fomento ao desenvolvimento social.

Durante os últimos 30 anos no Brasil, foram criados conselhos, secretarias especiais e coordenadorias governamentais em benefício das pessoas com deficiência em níveis municipal, estadual e federal; organizações não-governamentais; programas de apoio a projetos ligados à atuação dessa população e diversos fóruns de discussão sobre assuntos ligados à temática. $\mathrm{Na}$ área de cultura, pouco foi proposto ou apresentado, o que ocasiona pouco interesse nas ofertas dos museus por parte do público em questão. No entanto, não podemos deixar de ressaltar que a população de pessoas com deficiência representa $10 \%$ da população mundial; no Brasil os números correspondem a 25 milhões de pessoas.

Para atrair novos públicos é necessário que os museus e demais equipamentos culturais desenvolvam uma linguagem menos intelectual e científica, espaços de circulação mais simples, formas de mediação que considerem as diferenças e outras atribuições que devem ser percebidas, principalmente pelos gestores culturais responsáveis pelas instituições e pelo cumprimento de sua função social.

Segundo as novas discussões do ICOM, os museus precisam agir diretamente nas mudanças sociais, colaborando com o exercício da cidadania em suas propostas de relação com o público. Uma das principais mudanças sociais do século XXI pode ser considerada a prática da inclusão e a aceitação social em relação às diferenças humanas, o que pode ser constatado no sistema educacional, nas famílias, nos ambientes de trabalho e em outras esferas; além do fenômeno do aumento da expectativa de vida da população que deu um salto quantitativo, mas não eliminou as 
doenças degenerativas que causam a perda de capacidades. Diante desses fatos, deixar de oferecer acesso às manifestações e ao patrimônio cultural impede a consagração do museu como agente de desenvolvimento social, pois esse título não é ganho apenas pelo desenvolvimento de pesquisas e discussões teóricas, mas pelas ações que geram benefícios efetivos a toda população. 


\subsection{As conquistas dos movimentos de Inclusão Social e as mudanças na dinâmica dos museus durante a revolução cultural}

Os movimentos em defesa dos direitos das pessoas com deficiência, iniciados após o término da Guerra do Vietnã nos EUA, defendiam a participação dessa população em todos os benefícios sociais garantidos pelo estado. O movimento inicial, da década de 1960, foi o de Integração Social. A luta dos militantes do movimento conseguiu, em 1975, a aprovação da "Declaração dos Direitos das Pessoas Deficientes" na Assembléia Geral da ONU - Organização das Nações Unidas. O conceito prioritário deste movimento era a 'normalização', que significava basicamente:

Tornar acessíveis às pessoas socialmente desvalorizadas condições e modelos de vida análogos aos que são disponíveis de modo geral ao conjunto de pessoas de um dado meio ou sociedade. (SASSAKI apud MANTOAN, 1997 p. 32).

A criação de ambientes 'parecidos' com aqueles vivenciados pela população em geral desencadeava a proposição de um mundo separado, mas parecido com aquele em que vivem as demais pessoas. No entanto, a busca pela semelhança, em diversos aspectos, não favorecia o convívio efetivo entre as pessoas com deficiências e a sociedade.

Foucault, em seu texto intitulado 'As quatro similitudes', analisa as formas de representação inerentes à cultura ocidental; o princípio da analogia ou semelhança é considerado um elemento construtor da cultura que influencia diretamente a linguagem dos museus. É possível fazer uma transposição desse princípio à relação com o conceito da 'normalização' do Movimento de Integração Social. Da mesma forma que as manifestações artísticas anteriores ao modernismo buscavam imitar a natureza e os museus clássicos buscavam imitar as construções e decorações dos grandes impérios e forças políticas ligadas às religiões, o movimento de integração buscava oferecer às pessoas com deficiência um mundo separado que, entretanto, imitava os equipamentos da sociedade dita 'normal'. Apesar de sua inviabilidade no contexto cultural 
contemporâneo, socialmente a analogia ainda é aceita, seja na arte, nos museus ou na vida, pois seu poder, segundo a análise de Foucault, está na capacidade de organizar o jogo dos símbolos, lidar com as forças visíveis e invisíveis e guiar a arte de representação.

Tal afirmação pode ser comprovada pela forma de representação social da imagem da pessoa com deficiência. Há, por exemplo, estigmatização do cego pelo uso da bengala branca e dos óculos escuros nas imagens de pessoas com deficiência física nas propagandas e campanhas como Teletons, onde a escolha de padrões de beleza e o carisma são fundamentais (não existe comprovação científica da necessidade de uso de óculos escuros para pessoas cegas ou com baixa visão; essa convenção foi estabelecida com o objetivo de diferenciá-los dos demais usuários de bengala). Outro estigma é o das pessoas com deficiência intelectual, que sempre são apresentadas como alegres e inocentes; ou o das pessoas com deficiência auditiva, falsamente nomeadas e representadas como "surdos-mudos", o que não corresponde à verdade, pois a maior parte da população de surdos não tem problemas nas cordas vocais, só deixam de usar a voz pela falta de incentivo ou censura social pela dificuldade de controle de volume e clareza. Todas as formas preconceituosas de representação vêm sendo combatidas pelos indivíduos participantes do movimento de inclusão social, como parte da luta por sua individualidade e livre acesso à sociedade sem símbolos de uma identidade forçada e inexistente.

Aplicando este princípio da semelhança ao movimento de Integração Social, é possível concluir que a 'normalização' oferecia ao indivíduo uma estrutura social muito parecida à da sociedade, mas, em geral, em escolas especiais, oficinas protegidas de trabalho, universidades especiais, comunidades rurais afastadas dos centros urbanos e do convívio social, clubes esportivos e opções de lazer separadas (hoje o movimento de inclusão luta também pela extinção das "paraolimpíadas"). Oferta que, no entanto, não incentivava o convívio com a diferença, impedindo o direito básico de ir e vir da pessoa com deficiência, por meio da segregação em guetos. Atualmente, mesmo com a defesa dos parâmetros de inclusão, ainda existem sistemas sociais que reiteram as práticas de integração social, impondo às pessoas com deficiência opções muito 
parecidas com as oferecidas para a sociedade em geral, mas de forma separada, colaborando com a discriminação e com a idéia de que o tratamento especial é melhor por evitar as barreiras de uma sociedade ainda não preparada para inclusão.

A reiteração desse modelo, seja qual for sua justificativa, traz conseqüências retrógradas às propostas da inclusão social que tem mostrado progressivamente que a sociedade e o indivíduo se beneficiam mutuamente dos desafios do convívio. A normalização, portanto, perde o sentido de existência, podendo ser problematizada com base na reflexão oferecida por Foucault:

\begin{abstract}
Todo o volume do mundo, todas as vizinhanças da conveniência, todos os ecos da emulação, todos os encadeamentos da analogia são suportados, mantidos e duplicados por esse espaço da simpatia e da antipatia que não cessa de aproximar as coisas e de mantê-las à distância. Através desse jogo, o mundo permanece idêntico; as semelhanças continuam a ser o que são e a se assemelharem. O mesmo persiste o mesmo, trancafiado sobre si.

Convenientia, aemulatio, analogia e simpatia nos dizem de que modo o mundo deve se dobrar sobre si mesmo, se duplicar, se refletir ou se encadear para que as coisas possam assemelhar-se. (FOUCAULT, 1966 p. 41 - 42).
\end{abstract}

A semelhança aplicada aos equipamentos sociais é diretamente oposta à proposta de convívio com as diferenças; no entanto, apesar de seus problemas, o movimento de integração representou um importante elemento na aquisição de conhecimentos e experiências que, posteriormente, deu espaço para o surgimento do Movimento de Inclusão Social com seus parâmetros de equiparação de oportunidades. A superação das dificuldades, conquistada pelo grau de desempenho do indivíduo em programas de habilitação e reabilitação, proporcionou o desenvolvimento de lideranças que extrapolaram os limites físicos e sociais das instituições especiais e equipamentos sociais segregados.

No início da década de 1980, a inclusão surgiu proporcionando maior incentivo para que as pessoas lutassem por seus direitos e exigissem da sociedade civil respeito às suas diferenças. Sua principal atuação tem como característica trabalhar junto à sociedade para que esta se prepare para receber a pessoa com deficiência, sem discriminação e atendimento especial, respeitando as necessidades e potencialidades inerentes a cada indivíduo e proporcionando oportunidades equivalentes a todos. 


\begin{abstract}
A inclusão social é o processo pelo qual a sociedade e o 'portador de deficiência' (sic) procuram adaptar-se mutuamente tendo em vista a equiparação de oportunidades e, conseqüentemente, uma sociedade para todos. A inclusão (na escola, no trabalho, no lazer, nos serviços de saúde etc.) significa que a sociedade deve adaptar-se às necessidades da pessoa com deficiência para que esta possa desenvolver-se em todos os aspectos de sua vida. (SASSAKI, 1997 p.166).
\end{abstract}

Para incluir todas as pessoas, a sociedade deve ser modificada a partir do entendimento de que precisa ser capaz de atender às necessidades de seus membros considerando suas diferenças.

Desde as primeiras discussões em torno da Inclusão Social, suas propostas de ação promoveram significativas mudanças em diferentes segmentos sociais por meio de políticas públicas. É possível destacar as políticas educacionais de inclusão da criança e do jovem com deficiência no sistema educacional regular; as políticas de inclusão no trabalho garantidas atualmente por leis de cotas de emprego para pessoas com deficiência; e a inclusão em ambientes urbanos, garantida pela criação e desenvolvimento contínuo de normas técnicas, como a NBR 9050 - Norma Brasileira de Acessibilidade com sua última revisão em andamento e última versão de 2004.

Tais políticas, além de garantir os direitos da pessoa com deficiência na esfera pública, também promovem transformações na esfera privada; esta segunda busca um maior envolvimento com a causa através do conceito de 'Responsabilidade Social'. Podemos citar como exemplos casos de corporações que têm em sua política interna o compromisso com a contratação contínua de pessoas com deficiência em diferentes cargos; ou empresas de transporte e construção que adotam as medidas de acessibilidade em seus serviços e produtos; escolas e universidades particulares inclusivas que, em alguns casos, foram pioneiras na oferta de oportunidades equivalentes, como intérprete de LIBRAS para alunos com deficiência auditiva em sala de aula.

No caso dos museus, são necessárias formas alternativas de comunicação, mediação, planejamento espacial, ação educativa e cultural e desenvolvimento de políticas institucionais. No caso das propostas de mediação, que merecem atenção 
especial desta pesquisa por ser o canal de aproximação de novos visitantes e o meio de desenvolver a assiduidade de visitação, percebe-se que os programas desenvolvidos atualmente nos museus brasileiros ainda se baseiam na exploração visual e intelectual, recursos comuns ao museu-espetáculo. As exposições e propostas de mediação referenciadas na espetacularização, no entanto, deixam de explorar os outros sentidos de percepção dos indivíduos.

\begin{abstract}
Quando o mundo real se transforma em simples imagens, as simples imagens tornam-se seres reais e motivações eficientes de um comportamento hipnótico. O espetáculo, como tendência a fazer ver (por diferentes mediações especializadas) o mundo que já não se pode tocar diretamente, serve-se da visão como o sentido privilegiado da pessoa humana - o que em outras épocas fora o tato; o sentido mais abstrato, e mais sujeito à mistificação, corresponde à abstração generalizada da sociedade atual. Mas o espetáculo não pode ser identificado pelo simples olhar, mesmo que este esteja acoplado à escuta. Ele escapa à atividade do homem, à reconsideração e à correção de sua obra. É o contrário do diálogo. (DEBORD, 1967 p.18).
\end{abstract}

A abordagem visual baseada em recursos tecnológicos afasta o museu do diálogo com seus visitantes. Em exposições que utilizam abordagens multissensoriais é possível perceber que o interesse e envolvimento dos indivíduos são maiores; como exemplo temos as exposições com obras de artistas como Hélio Oiticica, Lygia Clark e Cildo Meireles; os dois primeiros, expoentes do movimento Neoconcreto brasileiro que questionava os suportes tradicionais das obras de arte e a interação entre a arte e as pessoas; após a realização de experiências exaustivas com composições de desenhos e pinturas de natureza geométrica que lidavam com a percepção visual, estes artistas começaram a experimentar suportes diferenciados e incluir em suas criações questionamentos ligados à cultura popular brasileira, à diversidade cultural e à sensibilidade do ser - humano. Oiticica desenvolveu trabalhos com linguagens contemporâneas como instalações e performances envolvendo outros indivíduos; propôs os "Penetráveis", instalações baseadas em planos de diferentes cores ligadas ao clima tropical brasileiro, os "Bólides", objetos táteis, visuais e olfativos com referências de parcelas materiais da cultura brasileira e os "Parangolés", obras de arte para o corpo, feitas a partir de tecidos ligados às indumentárias de escolas de samba e às manifestações populares. Estes últimos tinham como proposta que as pessoas os 
vestissem e se manifestassem livremente, para que então a obra fosse apresentada da maneira adequada, em movimento.

Lygia Clark também iniciou sua carreira com composições bidimensionais que brincavam com a percepção visual do espectador. Após algumas experiências ligadas à psicanálise e terapias alternativas, começou a criar obras que privilegiavam a participação do público, como os "Bichos", esculturas geométricas que pressupunham a interação na determinação de suas formas e o despertar da sensibilidade humana com obras como "O Eu e o Tu", macacões emborrachados contendo materiais que simulam partes do corpo do homem e da mulher para serem vivenciados por duplas, proporcionando uma intimidade proibida entre indivíduos. Posterior à fase de experimentações ligadas ao corpo humano, Clark iniciou a produção de objetos com caráter terapêutico através de objetos de arte criados pela mesma, os "Objetos Relacionais", confeccionados com materiais simples como sacos plásticos, água, elásticos, conchas e pedras que tinham como objetivo proporcionar o autoconhecimento nos indivíduos.

Cildo Meireles, artista contemporâneo brasileiro, utiliza em suas criações objetos do cotidiano, com questionamentos em relação à linguagem artística e a política (com maior presença em suas criações das décadas de 1970 e 1980). Um de seus trabalhos de grande destaque é o "Espelho Cego", uma caixa contendo material moldável em seu interior, onde as pessoas podem deixar o registro de suas mãos. Assim como o espelho visual, a imagem está em constante mutação, pois sempre que exposta pode ser manipulada pelo público.

Nas exposições recentes de trabalhos dos artistas, foi possível presenciar um crescimento significativo no número de visitantes em museus como Pinacoteca do Estado de São Paulo (Lygia Clark, 2006 e Hélio Oiticica, 2005), Museu de Arte Moderna de São Paulo (Lygia Clark, 2000) e na Bienal de Artes de São Paulo (edições de número 24 em 1998 e 25 em 2002), evento artístico de relevância internacional. A possibilidade de interação sensorial com a arte gerou mídia espontânea para as exposições que atraíram visitantes "de primeira viagem" aos museus. O volume e diversidade de públicos proporcionaram às instituições experiências que em alguns 
casos foram utilizadas em outras propostas interativas e inclusivas, como a exposição "Infinito ao Cubo" da artista Rejani Cantoni, em 2007, na Pinacoteca do Estado de São Paulo, onde os visitantes podiam entrar na instalação com devidas normas de segurança e conservação para vivenciarem a experiência, e o projeto de Inclusão Social da edição de número 27 da Bienal de Artes de São Paulo destinado a jovens moradores da periferia de São Paulo, que proporcionou ações de mediação na exposição e nos ambientes dos participantes.

Os exemplos provenientes das exposições e criações de artistas que lidaram com os sentidos e com as diferenças sociais e culturais, mostram que a mediação e o acolhimento nos museus são mais eficazes e atingem seus objetivos nas propostas de relacionamento sensível com os visitantes. O uso excessivo de recursos visuais e das informações intelectualizadas já vem sendo questionado desde a década de 1960, tanto pelo pensamento de Debord que influenciou o movimento estudantil ligado à revolução cultural, quanto pelos artistas contemporâneos influenciados pelas criações e conceitos de Marcel Duchamp.

Debord em seu texto "A Sociedade do Espetáculo" alertou que “... a crítica que atinge a verdade do espetáculo o descobre como a negação visível da vida; como negação da vida se tornou visível” (DEBORD, 1967 p. 16 grifo do autor).

Em oposição ao hipnotismo próprio da cultura do espetáculo, em 1968, na França, os estudantes iniciaram uma revolução cultural que também contribuiu para uma mudança na postura dos museus. Os revolucionários ligados aos equipamentos culturais ambicionavam uma museografia que respondesse às necessidades da obra e do público, com modos de representação mais didáticos do que os ligados apenas à contemplação da obra de arte.

\footnotetext{
Durante aquele período de manifestações, também os museus se converteram em espaços de contestação. O que se ambicionava nesse movimento, no tocante aos museus, era que as instituições museológicas deixassem de ser apenas depositárias de bens artísticos e culturais, passivas e elitizadas, bastião da tradição, para se tornarem instrumentos ativos e democráticos do conhecimento humano (RESENDE, 2002 p.30)
} 
Nesse sentido, artistas sintonizados com o espírito de época começaram a explorar a 'crítica institucional' em suas propostas artísticas, inspiradas principalmente pelos ready-mades de Duchamp ${ }^{3}$. A crítica a noções redutivas institucionais de 'espaço de arte' foi anteriormente explorada pelas vanguardas históricas e, neste movimento, a partir da década de 60 , resgatadas com maior coesão e efeito. O centro dessa crítica institucional era o conceito de 'cubo-branco', que representava um lugar imaculado, livre das interferências sociais, ideal à apreciação da obra de arte como objeto sagrado.

Essa mesma crítica institucional, potencializada nos anos 60, continuou presente nos questionamentos da arte contemporânea que, no entanto, ampliaram as fronteiras do 'cubo-branco', trazendo questões como negação do belo, convívio com as diferenças, diversidade cultural, linguagens apropriadas de outras áreas e apelo sensorial das obras de arte como subversão do espaço museológico, bem como uma ampliação das noções de lugar, uso e função da arte. Com base nesses conceitos da arte contemporânea, as ações culturais inclusivas começaram a se desenvolver como crítica institucional, deixando de lado a exclusividade da militância por direitos constituídos próprias dos movimentos sociais. A principal mudança vem ocorrendo nas propostas inovadoras de mediação cultural, ainda em desenvolvimento, voltadas ao respeito à diferença e às diferentes formas de comunicação e percepção.

A linguagem das exposições, seguindo as mesmas tendências, também precisa buscar alternativas ao uso recorrente e quase único da comunicação visual, pois este se encontra esgotado. A concepção de espaços e ambientes baseados nas diferentes formas de alcance e percepção, no acolhimento, permanência, conforto e ergonomia dos visitantes podem proporcionar a participação efetiva das pessoas na construção de sentidos no museu.

\footnotetext{
${ }^{3}$ Esses objetos utilitários, transfigurados de seus cotidianos e apresentados como obras-de-arte a partir de 1913 em espaços de arte consagrados, como Salões e Museus de Arte, estão na base da crítica institucional.
} 


\subsection{As mudanças na definição de museu segundo o ICOM}

Podemos considerar a inclusão de pessoas com deficiência um novo desafio para os museus, representando uma exigência social do século XXI, proveniente dos movimentos em defesa dos direitos das pessoas com deficiência que ganharam força na segunda metade do século $X X$.

Tomemos como ponto de partida o contexto de criação do ICOM - International Council of Museums (Conselho Internacional de Museus) que se deu em 1946, um ano após o término da II Guerra Mundial, constituindo-se como uma ONG que mantém relações formais com a UNESCO, tendo status de consulente no Conselho Econômico e Social da ONU. A partir da criação do conselho, responder oficialmente à pergunta "o que é museu?" passou a ser sua responsabilidade.

Na mesma década, a ONU criava o WCWB - Word Coucil for Welfare for the Blind (Conselho Mundial para o Bem-Estar dos Cegos), exatamente no ano de 1949, com sede em Paris. O órgão sempre teve em seu quadro de conselheiros e presidentes vítimas da II Guerra Mundial e da Guerra Fria, principalmente da União Soviética e países árabes. Na década de 1970, foi eleita a primeira mulher para a presidência do conselho, Dorina de Gouvêa Nowill, brasileira, cega e professora especializada em deficiência visual. A indicação marcou uma nova fase do W.C.W.B. dentro das práticas de Inclusão Social que também atribuíram valorização às mulheres.

Esse dado é aqui colocado com a intenção de esclarecer que os movimentos a favor dos museus e das pessoas com deficiência, desde o seu surgimento quase simultâneo, apresentaram características históricas e sociais semelhantes e interligadas. Como na criação dos primeiros órgãos de defesa acima citados, serão apresentados outros fatos concomitantes ligados aos dois assuntos.

O ICOM foi responsável pela realização do código de ética dos profissionais de museu. Nesse código, assim como no estatuto, apresenta-se a definição da palavra 'museu'. Desde sua criação existiram oito definições; nas mudanças ocorridas nessas definições, gradualmente surgiram algumas inclinações para a questão da inclusão de pessoas com deficiências. 
Em 1946, durante a primeira Assembléia, o Estatuto afirmava que:

\begin{abstract}
A palavra "museu" inclui todas as coleções abertas ao público, de caráter artístico, técnico, científico, histórico ou arqueológico, incluindo zoológicos e jardins botânicos, e excluindo bibliotecas, exceto as que mantêm exposições permanentes. (ICOM, 1946).
\end{abstract}

No momento de criação do ICOM ainda não existia uma preocupação em qualificar o termo "público" dentro da definição. O que, naquele contexto, significava ser aberto ao público? Quem eram os representantes da afirmação? Ao longo dos encontros, discussões e documentos realizados pelo conselho nas décadas seguintes, o termo 'publico' recebeu qualificações e conotações e a questão do envolvimento com os visitantes foi sendo explorada com a finalidade de validar os museus no processo de globalização das nações.

Em 1974 durante a 10aㅡ Assembléia Geral em Copenhagen, Dinamarca, o conselho adotou um novo Estatuto. Depois da crise das velhas instituições, causada pelos ideais da Revolução Cultural de 1968, muitos museus tiveram que rever sua atuação, pois a prática dos museus permanecia ligada à seqüência histórica de aquisição e conservação das coleções materiais que ainda precediam outras como comunicação e educação.

$\mathrm{Na}$ ocasião foi estabelecido um novo escritório internacional do ICOM, nos Estados Unidos da América; o contexto social americano era tenso, pois muitos soldados recrutados para a Guerra do Vietnã retornaram ao país com seqüelas que causaram deficiências. O governo americano, com sua política de bem-estar social, estava comprometido com a luta pela inclusão das pessoas com deficiência, como o pagamento de uma dívida às vítimas da guerra e suas famílias. Os benefícios alcançados pela luta das pessoas com deficiência privilegiaram outras parcelas da população socialmente excluídas como afro-descendentes, homossexuais e imigrantes. A inclusão social em ambientes culturais mereceu um reconhecido envolvimento do governo que questionou a definição de museu apresentada pelo ICOM, uma vez que não apresentava envolvimento e valorização do público dos museus. 
A primeira ação concreta para mudar a definição ocorreu entre 1998-2001, com a organização de uma força tarefa de reforma, cujo objetivo era rever a definição de museu presente no Estatuto. A coordenação foi assumida por Gary Edson ${ }^{4}$, antropólogo, Deputado Assistente ao Presidente dos EUA para casos econômicos e Conselheiro do Deputado de Segurança Nacional.

Edson defendia que a definição de museu em questão separava a instituição e seus qualificadores, como numa lista de compras. Em oposição, acreditava em uma definição que deveria conter características gerais de museus e não ficar descrevendo suas variáveis. O objetivo desta proposta inovadora era o de realizar uma pesquisa da relação dos museus com seus públicos em diferentes realidades sociais e econômicas dependentes financeiramente do sistema econômico americano.

A força tarefa proporcionou a participação de profissionais de diversos países que puderam colaborar com suas contribuições e inquietações. Algumas das sugestões consideram o acesso, o interesse e o benefício ao público pontos relevantes, o que representa uma nova postura diante da sociedade, abrindo precedentes para o reconhecimento da diversidade dos visitantes. Foi esquematizada, então, uma relação de 11 sugestões para a nova definição a partir das discussões que se deram pela lista da internet ICOM-L, submetida à votação para a nova definição de museu proposta pelo ICOM que é:

\begin{abstract}
Um museu é uma instituição permanente, sem fins lucrativos, a serviço da sociedade e de seu desenvolvimento, aberta ao público, que adquire, conserva, pesquisa, divulga e expõe, para fins de estudo, educação e lazer, testemunhos materiais e imateriais dos povos e seu ambiente.(ICOM, 2006, p.06)
\end{abstract}

Durante a realização desse trabalho em relação aos museus, os EUA enfrentaram o ataque terrorista a um dos principais símbolos de seu imperialismo: o

\footnotetext{
${ }^{4}$ Gary Edson graduou-se em antropologia na universidade de Stanford em 1977. Fez pós-graduação MBA em 1982 na Universidade de Chicago. De 1982 até 2001 ocupou diversos cargos na Presidência Americana. Em 2001, o presidente George W. Bush escolheu Edson para ser seu assistente para casos econômico-internacionais e conselheiro da segurança nacional.
} 
edifício World Trade Center, mais conhecido como Torres Gêmeas, no fatídico '11 de setembro', que abalou substancialmente a atuação das instituições culturais americanas, entre elas os museus. Os efeitos posteriores ao ataque determinaram uma nova era para a política americana, que perdeu a credibilidade da população do país e o caráter de força e poder diante de todas as nações por este dominadas. Para minimizar o efeito de depressão, foi necessário colocar as pessoas novamente em primeiro plano em diferentes esferas sociais e as instituições culturais estavam envolvidas nesta tarefa de cativar e acolher, pois a partir daquele momento a condição de bem-estar social e de segurança dos americanos sofreu um grande trauma.

Após todas as mudanças ocorridas no contexto social mundial, duas guerras mundiais civis pelo monopólio financeiro de fontes de recursos energéticos responsáveis pela destruição de importantes patrimônios materiais, e pela mutilação de pessoas envolvidas em suas batalhas, é possível afirmar que a mediação e a linguagem desenvolvidas pelos museus precisam ser críticas em relação às formas de relacionamento dos indivíduos, levando em consideração as diferenças na locomoção e percepção e novas maneiras de preservação do patrimônio cultural.

As definições de museu, enquanto instituição, foram resultantes de negociações que, ao longo do tempo, tiveram como fim acompanhar os diferentes contextos e realidades de cada época. A inclusão cultural de toda a diversidade de públicos e, por conseqüência, a acessibilidade às instituições culturais, apresentam-se como realidades do século $\mathrm{XXI}$ a serem reconhecidas e trabalhadas pelos museus para que estes desenvolvam plenamente sua função atribuída no século XXI pelo ICOM - a de se transformar em agentes de desenvolvimento social. 


\subsection{0 desafio da acessibilidade em museus}

Como já apresentado, podemos afirmar que a atuação do ICOM não se resume em definir teoricamente o que vem a ser um museu. As contribuições dos membros do conselho ao longo da segunda metade do século $X X$, reunidos em encontros e seminários, trouxeram novos conceitos e diretrizes para atuação dos museus frente à globalização, a espetacularização dos meios de comunicação e a inclusão social. Os novos paradigmas propostos por tais documentos elaborados a partir da década de 1950 traziam à tona questões como educação e comunicação.

No Seminário Regional da UNESCO sobre a Função Educativa dos Museus, realizado no Rio de Janeiro em 1958, foram colocados problemas essenciais para a transformação do museu em um elemento dinâmico dentro da sociedade. A consideração do museu como um espaço adequado para a educação formal conferiuIhe a capacidade de inserção dentro da comunidade. Os técnicos participantes de diferentes países concluíram, entre outras questões, que:

\footnotetext{
Havia de vencer-se o tradicionalismo do museu conservatório de objetos, onde se mostravam as curiosidades produzidas pelo homem ou pela natureza para transformá-lo em um meio de comunicação atrativo que pudesse incidir nos problemas reais da comunidade. (MATTOS e BRUNO, 1995 p. 09).
}

Nesse trecho, o museu é apresentado como um meio de comunicação que, por sua vez, precisa ser transformado com a intenção de estabelecer canais de aproximação com seu público. No mesmo documento, pontuou-se a necessidade de promoção de mudanças nas formas tradicionais de exposição, citando casos de exposição ecológica que levava em consideração o contexto de coleta do objeto e exposição polivalente e adequava a mensagem para um nível médio de visitantes com recursos audiovisuais e didáticos. Um dos exemplos utilizados nas palestras foi o Museu da Bocha, na França, que utilizava recursos auditivos nas estratégias de mediação da dinâmica de um jogo. Esse apontamento pode ser considerado como preâmbulo do desenvolvimento de propostas multissensoriais nos museus. 
O fenômeno exposição, como tal, vem passando por uma série de mudanças, conforme os contextos históricos e é evidente que as inovações tecnológicas apareçam sustentando as novas montagens e alterando o seu perfil tradicional. Hoje, o discurso museográfico não é apenas visual, mas plurissensorial. (BRUNO e ARAÚJO, 1989, p.14, in Cadernos Museológicos no. 2)

Os movimentos da museologia regidos pelos documentos resultantes dos encontros promovidos pelo ICOM depois da Revolução Cultural de 1968 contêm em sua essência uma repulsa pela espetacularização, concentrando seus esforços em afirmar os museus como agentes de desenvolvimento social.

Em 1972, durante a Mesa Redonda de Santiago do Chile, surgiu o termo 'Museu Integral' que correspondia à consideração dos problemas sociais no âmbito do museu e ao 'museu enquanto ação' - instrumento dinâmico de mudança social. No final da mesma década, o Movimento de Inclusão Social também surgia com seus conceitos de equiparação de oportunidades para todos os indivíduos e de eliminação de barreiras físicas e sociais que dificultavam esses princípios. Assim, o novo modelo de museu deveria considerar a inclusão de diferentes públicos como um problema social e enquanto ação deveria trabalhar pela mudança social em benefício do acesso facilitado para todos.

Em 1992, com a Declaração de Caracas, proveniente de um Encontro Regional do ICOM da América Latina, concluiu-se que ainda existia a carência de uma política cultural coerente que transcendesse à temporalidade e garantisse a continuidade das ações propostas pelos encontros e documentos elaborados nas ações dos museus. $\mathrm{Na}$ mesma declaração foram apontadas as necessidades de transformação das exposições - 'Monólogo em Diálogo', da educação em museus - 'Função Pedagógica em Missão Comprometida' e do conceito de museu - 'Museu Integral em Museu Integrado', conceitos respectivamente melhor compreendidos de acordo com sua elaboração original:

Que o museu deve refletir as diferentes linguagens culturais em sua ação comunicadora, permitindo a emissão e a recepção de mensagens com base nos códigos comuns entre a instituição e seu público, acessíveis e reconhecíveis pela maioria;

Que o processo de comunicação não é unidirecional, mas um processo interativo, um diálogo permanente entre emissores e receptores, que contribui 
para o desenvolvimento e enriquecimento mútuo, e evita a possibilidade de manipulação ou imposição de valores e sistemas de qualquer tipo...

Que o museu é um importante instrumento no processo de educação permanente do indivíduo, contribuindo para o desenvolvimento de sua inteligência e capacidade crítica e cognitiva, assim como para o desenvolvimento da comunidade, fortalecendo sua identidade, consciência crítica e auto-estima, e enriquecendo a qualidade de vida individual e coletiva... Que não pode existir um museu integral, ou integrado na comunidade se o discurso museológico não utilizar uma linguagem aberta, democrática e participativa. (MATTOS e BRUNO, 1995 p. 40).

Seguindo os princípios acima destacados, torna-se evidente que os museus, para corresponder a essas expectativas, precisam entender e colocar em prática os parâmetros do Movimento de Inclusão Social que defendem conceitos como a valorização das diferenças, a convivência dentro da diversidade humana e a equiparação de oportunidades. Conhecendo tais conceitos e seguindo a premissa de trabalhar proporcionando o protagonismo de seus beneficiários, os museus poderão de fato desenvolver uma linguagem acessível e reconhecível por meio da apresentação de conteúdos de forma multissensorial; contribuir com o desenvolvimento social, humano e crítico por meio de propostas de mediação que considerem as diferenças de seus públicos e propor novas formas de comunicação baseadas na participação e na interação de diferentes vozes. Assim, a integração do museu à comunidade trará benefícios endógenos e exógenos, que se enriquecerão mutuamente.

A Declaração de Caracas, por sua vez, representou um marco na atuação dos museus no final do século $X X$ e início do século $X X I$ a partir dos conceitos nela apresentados. Trabalhar pela educação, pelo desenvolvimento social, por formas de comunicação e mediação mais eficazes e pela acessibilidade pode ser considerado atualmente o principal desafio a ser trabalhado pelos museus.

Seguindo a mesma preocupação, o Código de Ética para Museus, redigido em 1986, revisado em 2001 e aprovado em 2004, apresenta no item 1.4 Acesso, a seguinte afirmação:

A direção deve assegurar que todos tenham pleno acesso ao museu, suas coleções e informações durante horários razoáveis e por períodos regulares. Deve ser dada atenção diferenciada aos 'portadores de necessidades especiais' (sic). (ICOM, 2006 p.8) 
Com essa afirmação, o ICOM delega a responsabilidade de garantir atenção para as pessoas com deficiência e mobilidade reduzida às direções dos museus. No momento da redação desse código de ética, oferecer uma atenção diferenciada já poderia ser considerado um avanço em relação à acessibilidade; no entanto, com todo o histórico de conquistas sociais a partir da década de oitenta do século vinte, é possível acreditar que os museus devem trabalhar para ir muito além da garantia de uma atenção diferenciada, revendo seu formato e planejamento frente ao paradigma da inclusão.

A partir dos conceitos de acesso, inclusão e novas linguagens desenvolvidos pelos documentos propostos pelo ICOM, cabe às instituições e aos órgãos responsáveis pelas unidades culturais assumirem seu papel no processo de inclusão cultural das pessoas com deficiência e mobilidade reduzida. O que podemos considerar até o momento é que a 'atenção diferenciada' solicitada no Código de Ética do ICOM vem sendo concretizada gradativamente por meio da criação de programas educativos e culturais inclusivos, projetos de acessibilidade e parcerias com organizações de atendimento e das próprias pessoas com deficiência.

No que diz respeito às adequações físicas para facilitar o acesso dos visitantes, podemos citar o trabalho do arquiteto Louis-Pierre Grosbois, responsável pelo projeto de acessibilidade espacial da Cidade das Ciências e da Indústria La Villete, na França, que é um exemplo bem sucedido na área. A planta do edifício tem três hectares e está situada entre o centro de Paris e a periferia leste da cidade; além do museu científico, o local também conta com um pavilhão de exposições e com um conservatório de música. Os edifícios em questão foram projetados de 1981 a 1983, com a prioridade de serem espaços acessíveis a toda diversidade de públicos. Esse objetivo foi considerado desde a proposta arquitetônica até a expografia e espaços de mediação interativa, elaboradas de 1983 a 1987, que levam os visitantes a refletirem sobre as dificuldades de circulação e fruição das pessoas com deficiência em espaços não adequados.

Os princípios que regeram o projeto foram três: circular - espaço de circulação vertical e horizontal sem obstáculos e discriminação, perceber - conteúdos apresentados em alturas adequadas a crianças e pessoas em cadeiras de rodas e 
apresentação de informações visuais claras e destacadas e manipular - experiências sensoriais para todos para melhor compreensão dos conteúdos apresentados.

Em um relato sobre o projeto, prioritariamente acessível e favorável ao convívio com as diferenças sem discriminação, Grosbois afirmou que há vinte séculos o arquiteto grego Vitrubio definiu a arquitetura como uma arte que responde a três necessidades: Comoditas, Firmitas, Voluptas, que se traduzem por Uso, Construção e Estética, defendendo que os museus que não podem acolher um público de todas as idades, com alguma deficiência ou sem ela, é porque não obedecem a uma das regras fundamentais da concepção arquitetônica: o uso. ${ }^{5}$

O pensamento de Grosbois apresenta-se dentro dos parâmetros do Desenho Universal, um conceito da arquitetura e do design baseado na diversidade humana. A idéia de um Universal Design surgiu após a Revolução Industrial, em questionamentos à massificação dos processos produtivos, principalmente nas edificações. O cerne do conceito era o porquê os ambientes eram criados sem levar em consideração as necessidades reais dos usuários. Na década de 1960 representantes do pensamento de países como Japão, EUA e nações européias uniram-se para questionar o modelo de produção para o 'homem-padrão', refletido nas concepções clássicas de ser humano (jovem, forte, alto, viril - o soldado espartano). Das discussões a respeito do padrão de ser humano utilizado pela arquitetura, foi criada a comissão Barrier Free Design, com o objetivo de estudar projetos de construções e design adequados às pessoas com deficiência e mobilidade reduzida. Na década de 1970 o movimento incorporou toda a diversidade humana em seu escopo, as gestantes, os idosos, as pessoas com limitações temporárias, os obesos e os anões e apresentou a denominação Universal Design. Essa tendência chegou ao Brasil na década de 1980 com as ações do Ano Internacional de Atenção às Pessoas com Deficiência (1981) e influenciou diretamente a criação da Norma Brasileira de Acessibilidade NBR-9050 no ano de 1985.

\footnotetext{
${ }^{5}$ Livremente adaptado do texto original Ergonomía Y Museología de Louis-Pierre Grosbois da publicação "Museus Abiertos a Todos los Sentidos".
} 
Nas décadas de 1980 e 1990, o arquiteto americano Ron Mace, que utilizava cadeira-de-rodas e um respirador artificial, com um grupo de colegas defensores da causa, desmembrou o conceito de Universal Design em sete princípios que devem ser seguidos por todos os projetos acessíveis. São eles:

1. IGUALITÁRIO - Uso equiparável: espaços, objetos e produtos que podem ser utilizados por pessoas com diferentes capacidades, tornando os ambientes iguais para todos;

2. ADAPTÁVEL - Uso Flexível: design de produtos ou espaços que atendam pessoas com diferentes habilidades e diversas preferências, sendo adaptáveis para qualquer uso;

3. ÓBVIO - Uso simples e intuitivo: fácil entendimento para que uma pessoa possa compreender, independente de sua experiência, conhecimento, habilidades de linguagem, ou nível de concentração;

4. CONHECIDO - Informação de fácil percepção: quando a informação necessária é transmitida de forma a atender as necessidades do receptador, seja ela uma pessoa estrangeira, com dificuldades de visão ou audição;

5. SEGURO - Tolerante ao erro: previsto para minimizar os riscos e possíveis conseqüências de ações acidentais ou não intencionais;

6. SEM ESFORÇO - Baixo esforço físico: para ser usado eficientemente, com conforto e com o mínimo de fadiga;

7. ABRANGENTE - Dimensão e espaço para aproximação e uso: que estabelece dimensões e espaços apropriados para o acesso, o alcance, a manipulação e o uso, independentemente do tamanho do corpo (obesos, anões, etc.), da postura ou mobilidade do usuário (pessoas em cadeiras de rodas, com carrinhos de bebê, bengalas etc.). ${ }^{6}$

\footnotetext{
${ }^{6}$ Extraído do guia Desenho Universal - um conceito para todos, publicado por Mara Gabrilli - vereadora da cidade de São Paulo, 2008.
} 
A aderência da arquitetura à inclusão social, entretanto, não pode ser limitada ao conceito de Desenho Universal. Outras tendências arquitetônicas também contribuíram com novas formas de concepção do espaço centradas nos usuários. Como exemplo desse pensamento no Brasil existe o trabalho de arquitetura de museus desenvolvido por Lina Bo Bardi, arquiteta italiana que projetou o edifício do MASP na Avenida Paulista, do MAM no Parque do Ibirapuera e do SESC Pompéia. Em suas criações e depoimentos registrados por pesquisadores e pelo instituto que leva seu nome, é possível identificar a preocupação com as pessoas que representam o público do museu no planejamento de seus projetos:

\footnotetext{
Lina Bo Bardi completou o seu pensamento afirmando que qualquer didática somente estaria viva quando se apoiasse num longo esforço de adaptação aos próprios indivíduos e respostas às suas urgências culturais e políticas. Seriam tais funções humanas que indicariam a forma adequada da arquitetura que deveria coincidir com a finalidade a que se destina o museu e a adequação ao ambiente no qual ele surge. (RESENDE, 2002 p. 46).
}

Nas áreas ligadas à mediação em museus - educação e ação cultural - os esforços em relação à inclusão social têm como função primordial desenvolver junto ao visitante a noção de pertencimento. Pela natureza da linguagem intelectualizada dos museus, a mediação tem se concentrado em minimizar o estranhamento do público e tornar o conteúdo das exposições acessível aos diferentes visitantes. Responsáveis por promover o acesso intelectual aos conteúdos da cultura institucionalizada, as propostas de mediação tornam-se especializadas, realizando os objetivos inerentes às políticas institucionais que geralmente são o aumento de público e as parceiras com o sistema de educação formal e as comunidades do entorno. Por conseqüência de sua função atual, os departamentos de educação passaram a ser os responsáveis pela inclusão de novos públicos, como as pessoas com deficiência, tarefa que deveria estar na agenda de todos os departamentos do museu, pois a acessibilidade envolve a eliminação de uma série de barreiras que extrapolam as atribuições da mediação.

Tendo como exemplo o desenvolvimento de diferentes atividades ligadas ao acolhimento do público nos museus, podemos afirmar que a inclusão poderá ser mais bem sucedida e aclamada pelos usuários quando presente na política de atuação 
institucional e em políticas públicas de acesso ao patrimônio cultural. A mudança necessária para que os museus sejam mais inclusivos depende do planejamento e da política de gestão institucional, para que essa atribuição seja então trabalhada em diferentes atividades, possibilitando ao usuário um serviço completo e não segmentado, ou 'pela metade'.

As novas funções assumidas pelos museus frente ao mundo globalizado e à inclusão social levam os equipamentos a desenvolver estratégias e planos de atuação mais participativos, colocando o indivíduo como o elemento central das relações. As mudanças se dão em diversas esferas que vão das políticas até a apresentação das exposições e contratação de colaboradores, pois o respeito às diferenças precisa ocorrer de fato, escapando do discurso retórico a favor da causa.

\footnotetext{
... O centro de atuação dos museus passa a ser as idéias que querem transmitir e para as quais se criam expografias significativas, e não apenas idéias possíveis decorrentes da natureza das coleções. De certa forma, referimo-nos a uma museologia criada à revelia dos "objetos herdados" e, nesse sentido, mais livre para tratar das questões relacionadas com o mundo em que vivemos, ou seja, a museologia da intervenção que ajude a sustentar, eventualmente, uma política cultural preocupada com as transformações do mundo que se confronta com o processo de globalização... (PRIMO, 2006 p. 91 in: MUSAS - Revista Brasileira de Museus e Museologia)
}

Primo, no trecho citado, afirma que os museus precisam extrapolar suas atribuições originais de conservação e exposição, para mergulharem um uma nova dinâmica social, na qual fazem parte da cadeia de desenvolvimento da sociedade e do indivíduo. As exposições precisam tratar de assuntos atuais e emergentes, como a inclusão social; precisam elaborar formas de aproximação com os públicos nãohabituais dos museus e contribuir com o crescimento das nações por meio do acesso à cultura, fundamental à melhoria na qualidade de vida da população. O escopo da acessibilidade tem muito a contribuir, fazendo dos museus espaços mais favoráveis ao acolhimento da diversidade.

Com base nas reflexões apresentadas é possível afirmar que a acessibilidade é um desafio que tem muito com que contribuir para os museus, pois beneficia grande parte da população, proporciona facilidades de acesso para diversos públicos e ajuda o museu e se desligar de sua origem elitizada, atributo que afasta as pessoas de seu 
espaço. Para tanto, as políticas culturais contemporâneas precisam desenvolver estratégias para que a acessibilidade seja incorporada em mudanças efetivas na natureza dos museus. 


\section{Capítulo 3 - Políticas Culturais de Acessibilidade em Museus segundo Gestores Culturais de Instituições Públicas, Privadas e Pessoas com Deficiência que freqüentam museus de diversas formas.}

Ao estudar propostas para uma política cultural inédita no cenário brasileiro, não podemos deixar de consultar os envolvidos em sua efetivação. No caso de uma política cultural de inclusão e acessibilidade em museus, os dois lados envolvidos no sistema representam as pessoas com deficiência e os museus (neste âmbito também estão incluídas as instituições culturais).

Com o objetivo de nortear propostas de política que viessem ao encontro das necessidades e possibilidades dos atores, a colheita de depoimentos de representantes do sistema foi integrada à metodologia da pesquisa. Assim, foram elaborados dois roteiros de depoimento: um atendendo às características das instituições museais, na figura de seus gestores; e outro focado nas questões da deficiência, destinado aos representantes do público em questão.

Os representantes foram selecionados com critérios de interesse e abertura em relação à temática, tentando sempre garantir a diversidade de atuações. Entre os gestores culturais foram convidados representantes de órgãos de cultura, museus públicos, museus privados, conselhos e de programas de formação. Já entre os representantes do público beneficiário foram convidadas pessoas com deficiência que já freqüentavam ou estabeleciam relações profissionais com museus.

Por se tratar de uma pesquisa qualitativa, o número pequeno de colaboradores faz parte de suas características. O objetivo do registro de entrevistas foi o de realizar, com base nas mesmas, uma análise substancial nos depoimentos dos indivíduos pertencentes ao objeto estudado.

O capítulo corresponde à análise dos dados primários coletados diretamente com representantes dos dois lados do sistema em questão e dos estudos de campo realizados em visitas técnicas aos museus e instituições culturais. 


\section{Uma análise realizada com atores reais do processo de inclusão.}

Uma política cultural deve ser realizada levando em consideração as estruturas culturais existentes e o público alvo. De acordo com esta afirmação, a análise aqui realizada representa a fundamentação principal desta pesquisa de mestrado: escutar, registrar, destacar e confrontar as opiniões, necessidades e realidades das pessoas com deficiência e dos gestores de instituições museológicas que atuam em diferentes níveis.

Os conceitos desse texto foram desenvolvidos com base nas entrevistas realizadas com participantes dos dois lados do sistema museus $\mathrm{x}$ pessoas com deficiência, com a convicção de que há muito que aprender ouvindo as pessoas contarem suas experiências com suas próprias palavras.

Nesta consulta, foi possível desconstruir as relações atuais aqui apresentadas, dando oportunidade para a identificação de entraves e caminhos para que a inclusão cultural seja desenvolvida plenamente. 


\subsection{O que dizem os gestores culturais das políticas culturais acessíveis às pessoas com deficiência.}

Esse grupo de depoentes foi constituído por representantes de diferentes instituições e esferas públicas ligadas à formação acadêmica, pesquisa/curadoria, órgãos de classe e diretores de instituições museais de grande representatividade para o Brasil. A escolha teve como objetivo contemplar uma diversidade de visões que pudesse abarcar diferentes instâncias que movimentam e determinam as diretrizes das políticas culturais.

Foram selecionados oito gestores de diferentes instituições e esferas públicas ligadas à formação acadêmica, pesquisa/curadoria, órgão de classe e diretores de instituições museais reconhecidas em nível nacional. A seleção também levou em consideração a experiência anterior destes gestores em relação à inclusão e acessibilidade aos museus, por meio de trabalhos anteriores, trajetória profissional e interesse. São estes:

- Carlos Roberto Brandão - Presidente do ICOM - BR (International Council of Museums - Comitê Brasileiro.

- Denise Grinspum - Diretora do Museu Lasar Segall - IPHAN - MINC e da Ação Educativa da XXVII Bienal de Artes de São Paulo.

- Felipe Chaimovich - Curador-chefe do MAM - SP (Museu de Arte Moderna de São Paulo).

- Maria Cristina Oliveira Bruno - Diretora do MAE-USP (Museu de Arqueologia e Etnologia da Universidade de São Paulo) e Coordenadora do Curso de Especialização em Museologia do MAE-USP.

- Mario Chagas - Coordenador Técnico do DEMU - Departamento de Museus e Centros Culturais do IPHAN - Instituto do Patrimônio Histórico e Artístico Nacional.

- Martin Grossmann - Diretor do Centro Cultural São Paulo - SMC-SP (Secretaria Municipal de Cultura de São Paulo) e Professor Titular do Programa de Pós- 
Graduação em Ciência da Informação da ECA-USP (Escola de Comunicações e Artes da Universidade de São Paulo.

- Ricardo Resende - Ex-Diretor (até início de 2007/época da entrevista) do Centro Cultural Dragão do Mar/ Museu de Arte Contemporânea do Ceará.

- Sílvia Antíbas - ex- Diretora do UPPM-SEC-SP (Unidade de Preservação do Patrimônio Museológico da Secretaria Estadual de Cultura de São Paulo).

É importante ressaltar que os depoimentos que deram base para as análises correspondem a um determinado período de tempo, no qual foram colhidas as entrevistas, entre outubro de 2006 e fevereiro de 2007. O período diz respeito ao espaço de tempo em que os convidados enviaram ou concederam suas colaborações; desta forma é possível afirmar que as conclusões aqui analisadas têm como referência o ambiente cultural e seus eventos entre os anos de 2006 e 2007.

No questionário aplicado com o grupo as perguntas investigaram: a ação do sujeito desde sua formação profissional e acadêmica e a conduta de sua atual ocupação em relação a iniciativas positivas e ações embrionárias de políticas culturais de acessibilidade em museus.

A primeira questão tinha como objetivo investigar o contato e convívio dos gestores com pessoas com deficiências em sua trajetória pessoal, acadêmica e profissional. $\mathrm{Na}$ análise geral das entrevistas, o resultado da questão é de extrema importância, pois afirma que o convívio com a diferença é fator de desenvolvimento pessoal e profissional.

A maioria dos consultados identificou ter trabalhado com pessoas com deficiência e os relatos das experiências deixaram clara a contribuição para o crescimento desses indivíduos. Alguns dos entrevistados levantaram pontos relevantes em relação ao convívio com pessoas com deficiência como o respeito à diversidade, a não subestimação de capacidades e o não tratamento das pessoas de forma assistencialista. Esses aspectos nortearam os princípios de garantia para que o museu inclua a pessoa com deficiência de forma integral e com respeito às suas diferenças. 
A segunda questão investigou em que medida os entrevistados incentivaram a criação de propostas culturais e artísticas para pessoas com deficiência em sua trajetória na área cultural.

A questão deu abertura para reflexão em relação ao alcance das propostas citadas. Dois pontos foram unânimes: a conclusão de que as ações realizadas até o momento não chegaram a configurar uma mudança na postura dos museus como um todo e a constatação de que os projetos inclusivos recebem visibilidade por parte da mídia e da sociedade, mas costumam ser temporários e ainda não têm perspectivas de integrar as políticas institucionais.

Com esta afirmação é possível verificar que a demanda por projetos de inclusão de pessoas com deficiência em museus não é incomum aos gestores culturais; no entanto, a resposta das instituições tem acontecido no âmbito da responsabilidade social, como uma prestação de contas à sociedade, ainda sem vislumbrar a integração do novo parâmetro na missão dos museus.

A terceira questão investigou o conhecimento do grupo sobre políticas culturais ou ações de acessibilidade no âmbito cultural. O objetivo da indagação era mensurar até que ponto as instituições brasileiras tomam conhecimento das tendências culturais dos países desenvolvidos econômica e socialmente. Alguns respondentes destacaram que o Brasil, no contexto das instituições culturais, está desenvolvendo estratégias para cumprir a legislação referente às adequações arquitetônicas para acessibilidade. Essa realidade pode ser comprovada com base em alguns exemplos de museus que estão adequando suas instalações físicas segundo os critérios da norma brasileira de acessibilidade NBR - 9050. Isto mostra a preocupação prioritária com rampas de acesso para pessoas em cadeiras de rodas, elevadores sinalizados em braile, eliminação de barreiras arquitetônicas e outros requisitos ligados a acesso físico.

No entanto, as adequações arquitetônicas não resolvem o problema por completo, pois os museus não são apenas locais de prestação de serviços básicos. $A$ natureza dos museus é ligada ao desenvolvimento cultural e educativo do indivíduo; por essa razão os equipamentos são utilizados por opção e não por obrigação ou necessidade. Para que as pessoas com deficiência tenham o direito de eleger a visita 
aos museus como opção de lazer e cultura precisam que as instituições tornem acessíveis não apenas sua entrada, saída e os sanitários, mas o conteúdo desenvolvido em seu universo patrimonial. A acessibilidade nos museus deve levar em consideração os aspectos sociais e comunicativos, além da questão espacial, que não deixa de ser indispensável.

Os gestores afirmaram de forma unânime que a militância em prol do acesso universal é de responsabilidade da sociedade civil, prioritariamente das pessoas com deficiência, beneficiários das ações em discussão. Essa questão gera uma grande polêmica, pois sabemos que o Estado é o responsável primeiro em garantir os direitos da população; no entanto, a sociedade civil tem grande influência na legitimação de políticas, não podendo ser relegada à posição exclusiva de receptora de benefícios. $O$ Movimento de Inclusão Social tem fundamental importância na sensibilização e na cobrança de atuação dos órgãos públicos, o que na prática já vem ocorrendo.

Foi senso comum a conclusão de que a acessibilidade ainda não se encontra no centro das políticas culturais institucionais ou públicas. As razões apontadas para o fato foram basicamente restrições financeiras. No entanto, nem todas as ações em benefício da causa precisam necessariamente depender de recursos financeiros. Criar situações de conscientização nas ações do museu, o que reitera seu papel de agente de desenvolvimento social, pode chamar a atenção do poder público e da iniciativa privada, incentivando o apoio para criação de políticas públicas e institucionais desta natureza.

A quarta e última pergunta tinha o objetivo de investigar a perspectiva de realização de ações culturais inclusivas no cargo atual dos participantes e de analisar sua contribuição para que a acessibilidade se torne questão prioritária em sua instituição.

Com base nas respostas, foi possível identificar casos de museus brasileiros que realizaram programas inclusivos sem contar com qualquer ajuda pública ou fiscalização em relação à legislação vigente. Esses exemplos foram capazes de mover a atenção do setor para o novo desafio. No entanto, os exemplos citados não deixaram de receber críticas em relação aos seus problemas e implicações. 
Em alguns casos citados, a predominância das mudanças físicas mostrou-se prioritária; outra constatação dizia respeito à dificuldade de estabelecer normas e princípios de acessibilidade em uma realidade que contempla instituições museais tão diversas. Alguns participantes acreditam que uma gestão em prol da inclusão social extrapola ações isoladas e programas temporários, fazendo com que a questão da diversidade de seu público seja incluída no regimento do museu. Sob esse aspecto também reconhecem a necessidade de trazer a inclusão para o universo museológico, trabalhando em diferentes frentes da instituição.

Os participantes mostraram consciência em relação a dificuldades de articular a questão por completo nas instituições, assumindo que a grande responsabilidade pela inclusão cultural de pessoas com deficiência é das instituições autônomas que deveriam se tornar exemplo de soluções para a sociedade e para a esfera museal e patrimonial.

Com base nas análises oferecidas na última questão, foi possível concluir que a situação do ambiente museológico no país é instável política e financeiramente, diversa em distribuição de renda e representatividade e que depende em sua maior parte de recursos e apoio governamental e de grandes patrocinadores da iniciativa privada. A realidade intimida ações inovadoras, já que no processo de tornar um museu acessível às pessoas com deficiência, existe uma grande mudança no padrão clássico de museu, o que nem sempre é entendido de forma positiva.

Como conclusão da analise das entrevistas foi possível perceber que os profissionais que conviveram com a diferença durante sua formação mostraram-se mais sensíveis à inclusão; outro ponto comum foi a recorrência na citação em relação às dificuldades burocráticas e financeiras que os museus brasileiros vêm enfrentando no início de seu desenvolvimento no ambiente cultural. Os principais entraves apontados para os programas inclusivos foram: a escassez de verbas de manutenção e o desconhecimento das leis e normas de acessibilidade pelos especialistas que prestam serviços aos equipamentos culturais. Com essa conclusão pode-se verificar os diferentes níveis de conscientização quanto à inclusão cultural por parte dos gestores culturais. 


\section{2 $O$ que dizem as pessoas com deficiência das políticas culturais acessíveis aos seus pares.}

De um lado foram ouvidos os gestores culturais que são os responsáveis diretos e indiretos pelas políticas públicas e institucionais e pelas tendências culturais. De outro, as pessoas com deficiência freqüentadoras de museu, que elegeram esse equipamento como opção de lazer. Entre os entrevistados foram selecionados profissionais da área de artes, educação e comunicação que, além de visitantes, também estreitaram relações de trabalho na área. O grupo representa os responsáveis indiretos pela divulgação dos museus nos movimentos sociais e instituições de atendimento e prestação de serviços às pessoas com deficiência e tem uma boa interlocução com o poder público, disseminando a aderência aos espaços como opção de cultura e lazer para outras pessoas com deficiência.

O roteiro de depoimento destinado ao grupo apresentou-se diferente em número de questões e conteúdo, já que esse lado do sistema, relacionado ao público alvo beneficiário das ações e das políticas, apresenta uma relação mais complexa com a análise, pois geralmente em seu processo de aquisição de autonomia social, o grupo enfrentou discriminação devido à sua condição. O questionário para este público foi composto por questões que investigaram desde a autonomia do indivíduo até a responsabilidade na conscientização dos museus quanto à inclusão.

Foram entrevistadas seis pessoas com diferentes deficiências e que apresentavam diferentes formas de relacionamento com os museus:

- Antônio Carlos Grandi - deficiente visual - Professor de Informática para Deficientes Visuais da Fundação Dorina Nowill para Cegos e Conselheiro Municipal do CAPPD - Conselho de Atenção à Pessoa Portadora de Deficiência.

- Evgen Bavcar - deficiente visual - Filósofo, Professor de Filosofia da Sorbonne, Crítico de Arte e Fotógrafo, com suas obras presentes em acervos e exposições internacionais de arte contemporânea.

- Eduardo Palma - deficiente físico - Arquiteto. 
- Leandra Migoto Certerza - deficiente física - Jornalista e Educadora.

- Sabrina Ribeiro - deficiente auditiva - Professora de artes.

- Cláudio Jorge de Jesus - deficiente intelectual e freqüentador de ateliês de arteterapia.

Também é importante destacar que os depoimentos correspondem a um determinado período de tempo, no qual foram colhidas as entrevistas, entre janeiro e abril de 2007. O período diz respeito ao espaço de tempo em que os convidados enviaram ou concederam suas colaborações; dessa forma é possível afirmar que as conclusões aqui analisadas têm como referência os eventos culturais e as discussões sobre inclusão entre os anos de 2006 e 2007.

A participação de Evgen Bavcar, fotógrafo esloveno cego merece atenção especial. Bavcar é um artista deficiente visual extremamente envolvido com os museus como visitante e profissional. Já veio ao Brasil diversas vezes para participar de exposições, produzir suas fotografias e para eventos da área de artes. Colabora com o Programa Very Special Arts do Brasil intitulado Arte sem Barreiras pela FUNARTE (Fundação Nacional de Arte do Ministério da Cultura). O convite deu-se no sentido de colher depoimentos críticos em relação aos museus brasileiros e estrangeiros podendo, assim, traçar um paralelo entre países com e sem políticas culturais de acesso ao patrimônio para pessoas com deficiência (França e Espanha, países citados pelo artista); ocorreu também com o objetivo de dar voz a um artista contemporâneo, deficiente visual, para analisar sua opinião quanto à acessibilidade em museus no aspecto de fruição. A entrevista foi concedida por telefone a pedido do mesmo; a língua para comunicação foi o espanhol, já que a pesquisadora não dominava a língua francesa e Bavcar não a quis conceder na língua inglesa. Depois de gravada em áudio, foi realizada a transcrição e tradução da mesma e envio para aprovação do colaborador. O depoimento está disponível na íntegra no Anexo de número 3 desta dissertação.

A primeira pergunta teve como objetivo identificar se o grupo considerava as visitas em museus como ferramenta para aquisição de autonomia, isto é, se o uso do 
equipamento cultural era válido em programas de reabilitação e iniciativas independentes.

Analisando as respostas foi possível verificar que as visitas em museus foram consideradas fundamentais no processo. Todos afirmaram ter realizado tais atividades comprovando que os museus são instituições consideradas relevantes tanto para as pessoas com deficiência, quanto para os profissionais da área de inclusão que incluem a atividade em programas de reabilitação física, social e profissional.

Para fins de esclarecimento, vale ressaltar que o processo de aquisição de autonomia nem sempre permanece ligado a instituições de atendimento às pessoas com deficiência. Em muitos casos, após deixarem as instituições, as pessoas passam por um período de adaptação em relação ao convívio social pleno e uso dos equipamentos sociais. Geralmente o período é apoiado por familiares ou amigos que acompanham a pessoa em atividades de lazer, pois é nesse caso que existe a maior insegurança. O receio pelo preconceito, por não ser atendido de forma completa e digna, o desconhecimento dos lugares da cultura transformam-se em uma barreira a ser superada. Os trajetos para o trabalho, escola, universidade não carregam a mesma insegurança em princípio, pois é sempre o mesmo local, os mesmos meios de transporte, o mesmo grupo de convivência e relação. Por mais que se mude um chefe, uma equipe, de sala, de professor, existe um aprendizado contínuo em relação aos equipamentos por seu uso cotidiano.

Já em equipamentos de lazer, como os museus e instituições culturais, o uso não é constante; por mais que se adquira uma presença assídua, as mudanças fazem parte do modus operandi do museu: as salas de exposição alteram-se a cada nova proposta; o espaço do museu algumas vezes passa por reestruturação completa como parte de uma proposta artística ou expográfica; as equipes de segurança, recepção e educação que são aquelas mais próximas do público geralmente são temporárias ou trabalham em sistema de rodízio por período. Todo este quadro instável colabora para que estes visitantes com históricos de preconceito, acidentes e incidentes, muitas vezes desistam da atividade. 
Pessoas com deficiência visual, por exemplo, por não possuírem parcial ou totalmente o sentido para identificar informações por meio da visão, não têm nenhum tipo de acesso informacional geralmente disponível em formato visual: as dimensões do museu, quantas pessoas estão ou costumam visitar o local, onde se encontram a recepção, os banheiros, bebedouros, cafeteria, qual é o eixo curatorial da exposição, entre outras informações. Na maior parte das vezes um educador (que em muitos casos não obteve em seu treinamento informações básicas de guia e atendimento para deficientes visuais) auxiliará a pessoa a encontrar respostas para todas suas perguntas visuais, no entanto, tal atitude única contribui para que a pessoa crie uma relação de dependência com os profissionais nas visitas aos museus. Quando quiser apresentar o local a amigos ou familiares não terá os mesmos referenciais que os outros visitantes, tendo que recorrer novamente ao profissional.

Uma pessoa com deficiência intelectual também apresenta diversos motivos para se sentir insegura em um museu em sua configuração atual, por motivos bem parecidos com os levantados em relação aos deficientes visuais, no entanto, enfrentando barreiras diferentes. A pessoa não se sente segura sozinha em espaços desconhecidos e pouco acolhedores física e visualmente, em ambientes pouco iluminados, com muitas informações, onde as pessoas disputam espaço para ter acesso a uma peça ou texto e sem um profissional que the ofereça informações e auxílios de forma tranqüila. As características descritas acima contribuem para a sensação de exclusão e para o desinteresse na interação com as exposições.

Pessoas com deficiências físicas têm dificuldades de acessar o museu, desde a saída de suas casas até chegar ao espaço, enfrentando barreiras físicas que geralmente são muito intensas. As pessoas com deficiências auditivas em muitos casos não conseguem entender as mensagens elaboradas pelo museu por seu caráter de erudição. Seu vocabulário é diferenciado pela alfabetização bilíngüe (LIBRAS - Língua Brasileira de Sinais e LPS - Língua Portuguesa para Surdos), o que agrava o preconceito em relação à sua forma de comunicação.

Uma parte do grupo considerou as visitas em museus como necessidade profissional ou opção de lazer. A experiência obteve diferentes conotações por parte 
dos entrevistados, no entanto, é unânime a questão de que o museu precisa ampliar e diversificar o acesso aos seus conteúdos, seja de forma física, comunicacional ou informacional. Restringir as formas de percepção e atender a demanda de pessoas com deficiência de forma assistencialista impede o aprofundamento da relação entre o público e as instituições. O direito e o desejo das pessoas com deficiência não têm limites definidos, bem como os demais públicos, geralmente contemplados com propostas adequadas: exposições especializadas, exposições blockbusters, temas de interesse geral, exposições lúdicas e outras propostas do gênero.

A segunda pergunta dizia respeito ao hábito de visitar museus. Diferente da questão anterior, esta tinha o objetivo de investigar a freqüência do grupo após o processo de aquisição de autonomia. O desejo de visitar os museus foi unânime, mas para que seja satisfeito de forma completa, apoiado pelas políticas culturais, faz-se necessário garantir o respeito em relação às formas de comunicação e locomoção desse público.

Também foram constatados alguns entraves que comprometem a freqüência das pessoas com deficiência: os de ordem maior, como transporte e acesso físico às vias urbanas dependem principalmente do poder público para ser solucionados; outros, de ordem interna, podem ser resolvidos dentro das práticas museológicas, como a adequação de recursos de comunicação e adaptação de conteúdos. Tendo conhecimento dos motivos, as instituições podem elaborar estratégias de ação para minimizá-los.

Nessa breve análise também foi possível destacar a ação das pessoas com deficiência na divulgação do museu para seu círculo de relações, o que beneficia a instituição com o alcance de novos públicos e com o aumento potencial de visitantes.

A terceira questão investigava a participação do grupo em propostas artísticas ou culturais em benefício de seus pares, como consultores, geradores de opinião e controladores de qualidade. O objetivo foi o de compreender a forma com que as instituições ou proponentes culturais consideravam sua participação no processo de elaboração e adequação de projetos culturais inclusivos. 
A maior parte dos entrevistados constatou que não teve oportunidade de intervir ou opinar por melhorias para si mesmo e para seus pares em ações culturais. A questão merece discussão, já que é de conhecimento geral que o lançamento de algum novo produto ou serviço implica em pesquisas e investigação junto ao público alvo consumidor.

Aqui é possível constatar o caráter de amadorismo de alguns serviços culturais oferecidos para pessoas com deficiência, o que prejudica o pleno desenvolvimento técnico e acadêmico da área. A avaliação é requisito básico para a implantação de qualquer proposta de cunho educativo e cultural e também uma forma de perceber erros e acertos para aprimorar constantemente o serviço oferecido. A participação do beneficiário no processo é fundamental, pois é este que poderá apontar onde se encontram os entraves e fornecer informações válidas para que o proponente elabore melhorias.

Com a análise aqui apresentada foi possível concluir que a elaboração de propostas inclusivas no Brasil, em sua maioria, não pressupõe a participação da pessoa com deficiência. As avaliações sistemáticas dos programas também não dão conta de aprofundar questões relevantes, passíveis de mover mudanças efetivas na dinâmica dos museus. O protagonismo das pessoas com deficiência, em propostas culturais ainda é restrito por razões burocráticas e de falta de investimento nos resultados de longo prazo.

A quarta questão solicitou ao grupo a realização de uma análise da situação dos museus em relação à acessibilidade, estabelecendo comparações com as políticas inclusivas de outras áreas sociais. O objetivo da indagação era investigar o conhecimento dos participantes sobre as políticas de inclusão existentes.

Os depoimentos mostraram-se fundamentais para o entendimento das questões envolvidas na relação museus $x$ pessoas com deficiência, proporcionando a identificação de pontos relevantes em relação às políticas culturais de acessibilidade em museus.

Bavcar, um dos entrevistados, colocou toda sua experiência crítica em relação às instituições que freqüenta como filósofo, escritor, professor, artista e visitante em 
uma realidade de inclusão cultural favorável às pessoas com deficiência que existe na Europa. Mesmo nos países que possuem políticas culturais de acessibilidade não considerou nenhuma prática inteiramente adequada.

Os demais entrevistados, cidadãos brasileiros que identificaram um ou mais exemplos de práticas adequadas, também não deixaram de manifestar sua opinião crítica no que diz respeito à criação de políticas de acessibilidade na cultura e em outras esferas sociais, o que mostra que o Brasil ainda está longe da situação ideal em relação aos direitos culturais das pessoas com deficiência. Essa realidade comprova que o país ainda tem muito a desenvolver na área, seja a partir de exemplos estrangeiros, nacionais, casos de museus inclusivos ou de outras esferas sociais.

As propostas de políticas culturais de acesso não podem deixar de levar em consideração as opiniões de seu público alvo, para garantir a solução efetiva dos impasses envolvidos no sistema em questão.

A quinta e última questão possibilitou que os participantes oferecessem exemplos de ação como forma de reiterar seu direito de acesso ao patrimônio cultural. O objetivo era oferecer um espaço de expressão de suas opiniões e críticas em relação aos museus e aos movimentos em defesa dos direitos das pessoas com deficiência.

Foram relatadas experiências pessoais e opiniões que demonstram um conhecimento profundo dos conceitos de inclusão social, além de exemplos de ações fundamentais para que o acesso à cultura seja efetivo. A idéia de enviar manifestos e documentos mostra o empenho dos entrevistados em propiciarem moções em benefício próprio.

É muito comum que os responsáveis pela gestão de museus pensem que as pessoas com deficiência não configurarão um público cativo, ou que sua freqüência será pequena, elegendo sempre outras prioridades, deixando os programas inclusivos para segundo plano. Essa idéia está completamente equivocada em relação às informações colhidas nas entrevistas que comprovaram que as pessoas com deficiência já estão começando a militância por seus direitos culturais.

A análise da última questão permitiu concluir que as pessoas com deficiência têm a plena consciência de seu papel como agentes de mudança em relação à 
inclusão. O Brasil ainda não possui uma legislação na área cultural que dê conta da garantia dos direitos das pessoas com deficiência. Até que exista uma política ou lei em defesa da causa, os beneficiários e os gestores culturais precisam trabalhar em parceria para tornar a questão pública, pois, apesar das enormes dificuldades financeiras, burocráticas, políticas e discriminatórias, os dois agentes - museus e pessoas com deficiência - precisam assumir o compromisso de lutar pelo objetivo maior: garantir o acesso ao patrimônio cultural livre de barreiras. 


\subsection{Ofertas de Acessibilidade em Museus Brasileiros - relato crítico do cenário atual da acessibilidade em museus e equipamentos culturais.}

No item anterior foram analisados os depoimentos de pessoas com deficiência e gestores culturais responsáveis pela área museológica, que forneceram informações importantes sobre as principais questões que engessam as ações de acessibilidade no sistema.

Nesta parte será relatado criticamente o conjunto de visitas técnicas em museus brasileiros realizado pela autora em companhia de pessoas com deficiência (na maioria das vezes), levando em consideração os principais pontos levantados nos depoimentos do público beneficiário.

Como já relacionado anteriormente, como parte da coleta de dados primários para esta pesquisa, foram realizadas visitas técnicas com caráter avaliativo entre os anos de 2006 e início de 2008 (período de realização da pesquisa). O critério para seleção dos espaços visitados foi a oferta de serviços (exposições, propostas artísticas, espaços culturais, centros culturais e eventos) com inclinações para a inclusão de pessoas com deficiência, adequações de acessibilidade ou abordagem multissensorial.

No Anexo 1 desta dissertação, encontra-se a relação completa de locais visitados, no entanto, este texto se atém a analisar criticamente os casos mais significativos para o desenvolvimento da discussão acerca de políticas e ações culturais de acessibilidade em museus.

No balanço geral das experiências vivenciadas foi possível constatar que ações de acessibilidade e inclusão de pessoas com deficiência são apreciadas pelos colaboradores das instituições, que se encantam pela riqueza de experiências suscitadas a partir de novas formas de apresentar o museu ou o conteúdo de uma exposição para públicos anteriormente excluídos do ambiente cultural. Também é possível notar que existe uma ansiedade no sentido de captar e cativar um número significativo de visitantes para as ofertas que apresentam essa abertura, no entanto, é possível afirmar que ainda não existe uma cultura de adequação e inclusão nos serviços culturais já existentes e estabelecidos. A formação de novos públicos sempre 
passa por um processo de reconhecimento, apreciação, crítica e adequações para, então, ser legitimado pelos usuários aos quais de destina a ação. A ansiedade em captar as pessoas com base em estimativas quantitativas, em muitos casos, não contribui para o desenvolvimento da acessibilidade no ambiente cultural e para o aumento nas opções de lazer e cultura das pessoas com deficiência. As opções de cultura, como já expressam em seu nome, são paliativas às preferências e gostos pessoais de cada indivíduo e não uma obrigatoriedade. As pessoa com deficiência apreciam as ações culturais de inclusão para si e para seus pares, mas não é a simples oferta que as motiva a disporem de seu tempo em propostas que não lhe interessam. Essa é uma realidade que ainda não é considerada pela maior parte dos proponentes de projetos e programas de inclusão em museus, pois a vaidade de seu trabalho inusitado e escasso nos equipamentos culturais torna-se superior ao respeito às diferenças, que deveria ser a motivação das propostas em questão. Também devemos considerar que, na maior parte dos casos, a preocupação em acolher as pessoas com deficiência acontece de forma oportuna, isto é, quando o museu e/ou espaço cultural recebem exposições temporárias que já trazem a acessibilidade em seu escopo; projetos especiais desenvolvidos com aporte financeiro de grandes patrocinadores e em iniciativas que envolvem a divulgação de responsabilidade social de corporações privadas. É possível afirmar que a inclusão, segundo seus princípios teóricos e de atuação, é quase inexistente no cenário dos museus, pois o atendimento 'especial' é próprio das práticas integracionistas ligadas ao conceito de normalização. O desenvolvimento da acessibilidade só ocorre de fato quando o equipamento planeja e inclui o respeito às diferenças, por meio da acessibilidade, em ações que beneficiem todos os seus públicos de forma equitativa e não segreguem as pessoas por suas deficiências.

Nas visitas técnicas foi possível identificar poucas iniciativas genuínas, isto é, que nascem da conscientização do gestor cultural, ou do conselho da instituição e que são progressivamente incluídas nas diretrizes de atuação e na missão dos espaços.

Dentre os poucos casos de iniciativas genuínas, foi possível identificar o ECCO Espaço Cultural Contemporâneo de Brasília, que iniciou sua atuação durante o Festival 
Sem Limites, promovido pela FUNARTE - Fundação Nacional da Arte do Ministério da Cultura, sob consultoria da autora dessa pesquisa; foi uma oportunidade pontual de desenvolver a proposta de acessibilidade junto à diretoria, com o envolvimento de toda a equipe fixa, temporária e prestadores de serviço da instituição. Os princípios que regeram o desenvolvimento do programa de acessibilidade, atualmente incorporado na missão do ECCO, foram: a sensibilização e conscientização da equipe; o estabelecimento de parcerias com organizações governamentais, não governamentais e privadas de atenção às pessoas com deficiência e escolas inclusivas; a inclusão de pessoas com deficiência no quadro de colaboradores da instituição e a diversificação da programação do espaço com base na celebração das diferenças.

Por conta do evento 'Sem Limites', que reúne bienalmente a produção artística de pessoas com deficiência, o ECCO recebeu em seu espaço a exposição "O que é normal" que questionava os parâmetros da normalidade e das diferenças. A diretoria do espaço, sob consultoria especializada, desenvolveu uma proposta de ação educativa que visava aprofundar as questões da curadoria da exposição e estendeu este benefício nas ações de formação de professores e na capacitação dos educadores responsáveis pela condução das visitas educativas. Por meio das parcerias garantiu a produção de publicações da exposição em braile, a contratação de uma educadora intérprete de LIBRAS e, conseqüentemente, a presença maciça de pessoas com deficiência nesta e nas outras exposições oferecidas. A programação cultural do ECCO oferece constantemente palestras, debates, apresentações artísticas com diferentes linguagens, exposições e cursos com foco na inclusão da pessoa com deficiência.

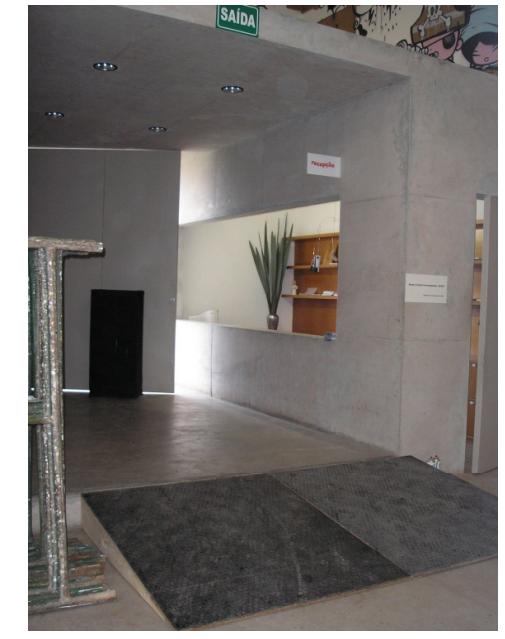

Figura 4. ECCO - Espaço físico acessível, 2006

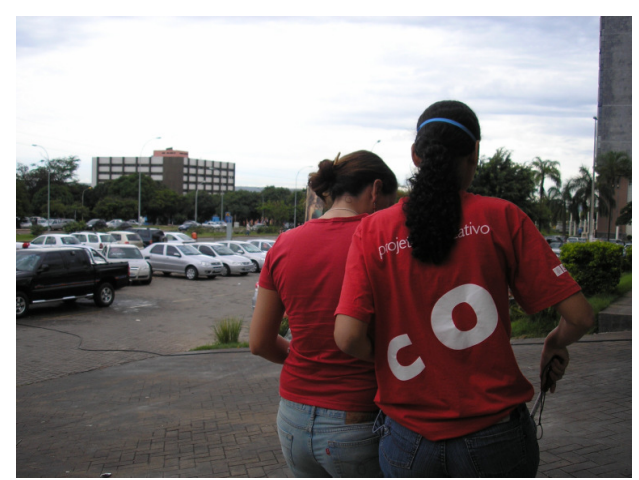

Figura 5. ECCO - Treinamento da equipe para trabalho com pessoas com deficiência, 2006. 
Um caso semelhante ao acima mencionado só ocorreu no Brasil, de forma pioneira e isolada, há mais de vinte anos no início da década de 1980, durante o projeto do Museu da Indústria, Comércio e Tecnologia (extinto na mesma década) coordenado por Waldisa Camargo Russio, um dos nomes mais significativos no que diz respeito ao desenvolvimento acadêmico e profissional da museologia internacional. Russio, que participava ativamente das discussões na área museológica e cultural do ICOM, ao se deparar com a inclusão de pessoas com deficiência nas equipes das indústrias paulistas, que era o objeto de sua pesquisa, trabalhou intensamente na participação das entidades e da comunidade de pessoas com deficiência no museu, promovendo eventos, exposições e palestras sobre a participação desta população no desenvolvimento econômico do país. O caso tem como ponto crucial o envolvimento dos alunos de Waldisa, coordenadora do Curso de Especialização em Museologia oferecido pela FESP - Fundação Escola de Sociologia e Política de São Paulo e o programa de ação cultural inclusiva do museu, com ênfase na participação e no desenvolvimento da consciência crítica dos colaboradores e visitantes do projeto.

Uma das iniciativas visitadas que também indica um crescimento qualitativo em relação à inclusão, foi o projeto de Ação Educativa para Deficientes Visuais, realizado pelo Museu de Zoologia da Universidade de São Paulo. Apesar dos impasses institucionais relacionados à reduzida equipe técnica composta por uma educadora fixa, Márcia Fernandes Lourenço com formação em biologia - que atende todos os grupos escolares que agendam visitas e é responsável pelas ações de extensão e divulgação científica do museu - e uma equipe que oscila entre 02 e 04 estagiários voluntários (alunos da área científica que cumprem no museu a etapa de estágio obrigatório exigido pelas faculdades), somada a dificuldade de divulgação do serviço pela insuficiente estrutura de difusão cultural do museu, o projeto conseguiu se manter na mudança de gestão e envolver os estudantes que realizam estágios temporários na instituição, investindo na conscientização dos jovens por meio do desafio de criação de propostas educativas inclusivas para a área da biologia, como conclusão do estágio. 
Atualmente o Museu de Zoologia, contando com a mesma equipe na área de educação, está ampliando o programa, por meio de novas oportunidades de apoio e pela diversificação de produtos acessíveis.

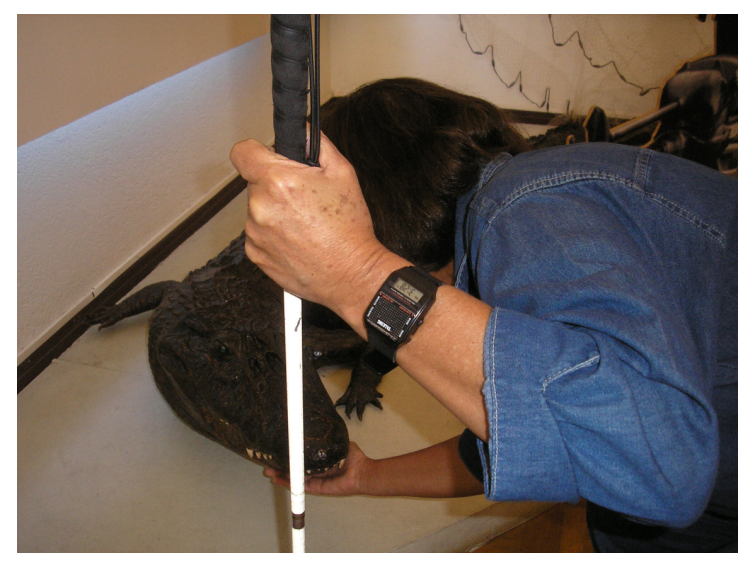

Figura 6. Projeto de Ação Educativa para Deficientes Visuais - Museu de Zoologia, 2006.

Com características semelhantes à experiência do Museu de Zoologia da USP, podemos traçar um paralelo com a atuação pioneira do MAC - Museu de Arte Contemporânea, também ligado à Universidade de São Paulo. O museu teve sua primeira abertura à inclusão de pessoas com deficiência no ano de 1985, sob gestão de Aracy Amaral. Nesse momento, a diretora apoiava a criação do primeiro programa de educação do museu, sob responsabilidade de Martin Grossmann, orientador desta pesquisa. A primeira ação do novo departamento seria inaugurada durante uma exposição de esculturas do acervo, que teve como desafio lançado por Aracy Amaral o acesso tátil da coleção para pessoas com deficiência visual. A experiência inusitada em apresentar o museu de arte para o público em questão, até então afastado do contato com a criação artística, abriu portas para novas formas de interação do público em geral no MAC. Para as pessoas com deficiência, o projeto vislumbrou novas possibilidades de acessar a arte para seu desenvolvimento cultural. Após a primeira iniciativa, na década de 1990, com o apoio e experiência acumulada por Grossmann, a nova diretoria do museu, sob responsabilidade de Ana Mae Barbosa, apoiou o desenvolvimento do Programa Museu de Arte e Público Especial elaborado por 
Amanda Tojal. O programa atendeu pessoas com diferentes deficiências, produziu materiais multissensoriais de apoio à fruição da coleção do museu, capacitou estudantes universitários que atuaram como estagiários e envolveu outros profissionais do museu em projetos de exposições especiais por mais de dez anos. No ano de 2003 a coordenadora e alguns membros da equipe desta experiência passaram a integrar o programa educativo da Pinacoteca do Estado de São Paulo, com o PEPE - Programa Educativo para Públicos Especiais, onde estão até o momento.

No Museu de Zoologia, mesmo com a predominância da área de pesquisa na política institucional, são mais de 40 pesquisadores e apenas 02 técnicos na área de Difusão Cultural; o projeto inclusivo conquistou a simpatia de boa parte dos docentes que pesquisam a coleção, podendo assim dar continuidade às suas ações de forma gradual e com parceria com instituições, empresas e outros museus que trabalham com foco na promoção da acessibilidade.

Outro caso vivenciado durante a pesquisa foi a visita à exposição "A Célula ao Alcance das Mãos” promovida pelo Museu de Ciências Morfológicas da UFMG Universidade Federal de Minas Gerais, sob diretoria da Prof. Maria das Graças Ribeiro. A exposição, elaborada pelo museu com base em uma coleção didática produzida por professores e alunos da disciplina de citologia da universidade para atender à demanda de estudantes com deficiência visual, foi emprestada temporariamente para a biblioteca do Campus Universitário SENAC de São Paulo. Pela qualidade e importância do material apresentado, a exposição ganhou visibilidade da área cultural percorrendo as principais capitais brasileiras. O campus do SENAC ao receber a mostra deparou-se com o universo da deficiência, o que abriu uma nova possibilidade de atuação da biblioteca. Apesar do caráter temporário da exposição (1 mês), os impactos da mesma moveram mudanças na conduta da instituição que a recebeu e que, dentro de suas atribuições, continua atuando de forma inclusiva, ampliando o acervo de obras em braile e na contratação de pessoas com deficiência. 


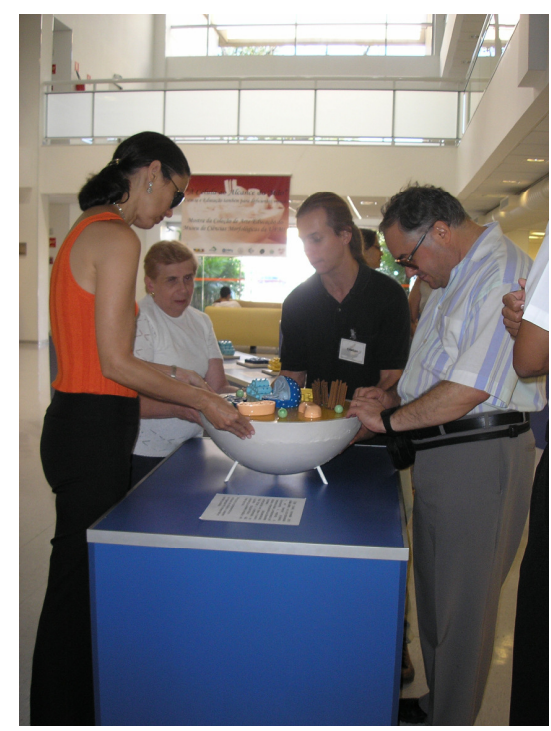

Figura 7. Exposição "A Célula ao Alcance das Mãos" - Biblioteca do Campus Universitário do SENAC 2007.

O Sabina - Cidade do Conhecimento em Santo André - SP apresenta uma exposição científica com ênfase na interatividade. Diferente da biblioteca do Campus Universitário SENAC, antes da inauguração, desde o planejamento espacial, curadoria e programa educativo, os responsáveis pelo projeto buscaram conhecer os conceitos e iniciativas de acessibilidade existentes no Brasil. O espaço cultural e científico oferece aos visitantes a circulação livre de barreiras arquitetônicas, um programa educativo inclusivo que auxilia o visitante na experimentação autônoma dos simuladores tecnológicos e a sensibilização quanto à inclusão nas exposições temporárias que ocupam parte do local. Com essa conduta, o Sabina - Cidade do Conhecimento garante lugar entre as instituições que desenvolve uma política institucional acessível, pois os benefícios gerados pelas facilidades oferecidas atingem não apenas as pessoas com deficiência, mas todos os visitantes do espaço, o que é um caso raríssimo no Brasil, mas que tem seus referenciais em exemplos de centros de ciências espalhados pela Europa e EUA.

As iniciativas citadas acima de planejamento e adequações para acessibilidade física e intelectual são de extrema validade, no entanto, o investimento em formação de público é fundamental para despertar o interesse das pessoas com deficiência pelos 
museus, pois configura um hábito pouco praticado por essa população no Brasil, por serem raros e recentes os programas culturais que proporcionam o acesso adequado. Nesse sentido, uma das experiências de interesse na seara da formação de público foi o Curso de História da Arte para Deficientes Visuais, iniciativa oferecida pelo MASP Museu de Arte de São Paulo no ano de 2006. O curso, patrocinado pela Secretaria Estadual de Cultura de São Paulo, por meio do Projeto Talentos Especiais, que promove oficinas culturais para pessoas com deficiência em instituições especializadas e espaços culturais, teve como proponente e docente a educadora Valquíria Teixeira, que atua como assessora do Secretário Municipal da Pessoa com Deficiência. O projeto experimental explorou as possibilidades da estética e história das artes visuais para pessoas com deficiência visual. O objetivo proposto pelo curso era o de instrumentalizar os participantes com o entendimento da linguagem e das estruturas formais da arte em seus diversos movimentos, para que nas visitas aos museus e exposições de arte a fruição e entendimento das obras pudessem acontecer sem a barreira de linguagem que dificulta a compreensão da natureza da criação artística. A oficina teve a duração de um semestre e ocorreu dentro da estrutura do Ateliê de Arte do museu. Apesar de seu pioneirismo na formação de público de pessoas com deficiência visual em museus de arte, até o momento o MASP não estendeu a experiência acumulada na iniciativa a uma proposta de mediação cultural inclusiva, o que poderia influenciar a criação de uma política cultural acessível no museu. As ações inclusivas, para se configurarem em políticas e, por conseqüência, opções de cultura efetivas ao público alvo, precisa permear várias frentes de atuação do museu, como o atendimento aos visitantes, a produção de publicações e materiais educativos, 0 programa de extensão e formação e a inclusão profissional. Assim, é possível concluir que a experiência promovida pelo MASP teria potencial para conformar uma política institucional desde que devidamente multiplicada em outros departamentos e iniciativas. 

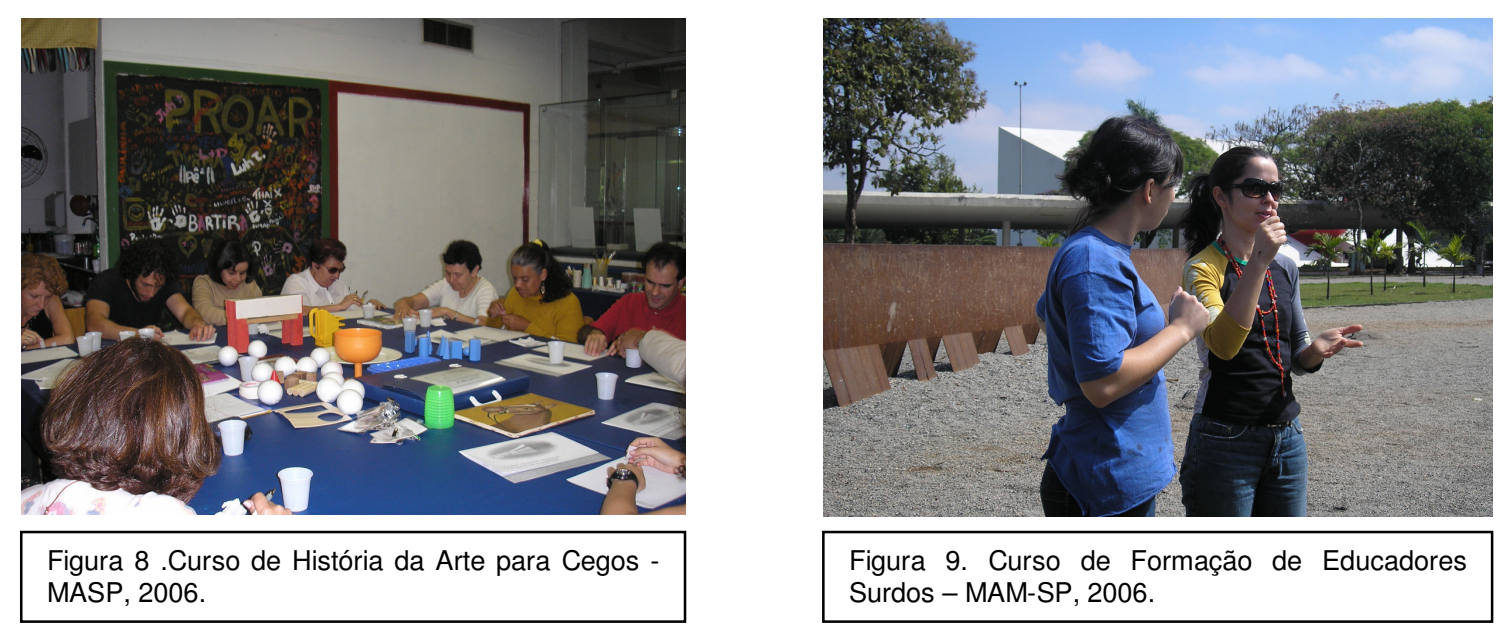

Figura 9. Curso de Formação de Educadores Surdos - MAM-SP, 2006.

Uma experiência de formação de público que, no entanto, não acontece isolada, são os cursos de formação profissional e artística promovidos pelo Programa Igual Diferente do MAM - Museu de Arte Moderna de São Paulo. O MAM, apesar de na década de 1990, promover algumas iniciativas isoladas voltadas à inclusão de pessoas com deficiência, só na década de 2000 inaugurou o programa que atualmente está sob coordenação de Daina Leyton, psicóloga. Suas ofertas iniciais diziam respeito ao atendimento de grupos de pessoas com doenças mentais e deficientes auditivos nas exposições. Refletindo sobre as dificuldades de comunicação com as pessoas com deficiência auditiva em relação aos conteúdos artísticos, o programa criou um curso de formação em arte moderna e contemporânea para pessoas com deficiência auditiva. Com a proposta tem a oportunidade de formar educadores surdos especializados em mediação de exposições de artes que podem atuar no próprio museu e outras instituições, além disso, proporciona o enriquecimento da Língua Brasileira de Sinais LIBRAS, com a inclusão de novos termos inerentes à linguagem cultural e artística. $O$ museu também investiu nas adequações arquitetônicas do edifício, eliminando as barreiras de acesso às pessoas com deficiência física e visual. O novo projeto do programa é a oferta de cursos de criação artística inclusivos, que já contam com participação de pessoas com doenças mentais, deficientes visuais e auditivos. A primeira iniciativa desenvolvida com base em novas formas de relação com a arte e com o museu é o curso de fotografia Imagem e Percepção; o curso será realizado no 
segundo semestre de 2008 e foi influenciado pelos conceitos problematizados nas obras do fotógrafo cego Evgen Bavcar de visão e não visão e pela participação de uma aluna com baixa-visão no curso de fotografia semestral.

Até o momento citamos casos de museus e instituições culturais de caráter permanente em suas iniciativas que permeiam os conceitos de acessibilidade. Como a área dos museus contempla as exposições temporárias e os espaços culturais de empresas, a metodologia da pesquisa também considerou as ofertas dessa natureza. Analisaremos dois dos casos mais significativos da categoria, já que nesses espaços também existem políticas institucionais de atuação e relacionamento com o público, com o objetivo de afirmar a responsabilidade social e cultural da empresa, ou com o objetivo de atrair um maior número de pessoas no caso dos espaços culturais de exposições temporárias blockbusters.

A OCA (edifício do conjunto arquitetônico de Oscar Niemeyer do Parque do Ibirapuera, pertencente à Prefeitura Municipal de São Paulo) é um dos espaços culturais de maior visitação na cidade por receber exposições internacionais de interesse geral e investir em formas de divulgação massiva na mídia. A Exposição "Corpo Humano", com corpos e fragmentos do corpo humano conservados por uma técnica de polimerização que preserva a integridade dos tecidos para estudos; e "Leonardo da Vinci", com réplicas de seus trabalhos artísticos, arquitetônicos, mecânicos e demais inventos, foram oferecidas concomitantemente no edifício no ano de 2007. Apesar do grande apelo das exposições para o público com deficiência e da tentativa de parceria por parte da Fundação Dorina Nowill para Cegos, manifestado pela autora da pesquisa em seu cargo de consultora de acessibilidade em museus, em princípio não houve resposta por parte da organização das exposições. Nas últimas semanas do evento, após a participação de um membro da supervisão educativa do evento no Workshop Comunicação Museológica Acessível ao Deficiente Visual, oferecido pela mesma fundação, foi elaborado um convite para que as pessoas com deficiência visual visitassem a exposição com a possibilidade de acesso tátil às peças expostas. Apesar da louvável iniciativa, é possível considerar que o despertar tardio para a questão não chegou a promover mudanças na conduta dos colaboradores do 
evento e nem mesmo no processo de divulgação da exposição, o que reitera a posição desta pesquisa que acredita que as políticas de acessibilidade precisam ser desenvolvidas na missão e no regimento das instituições.
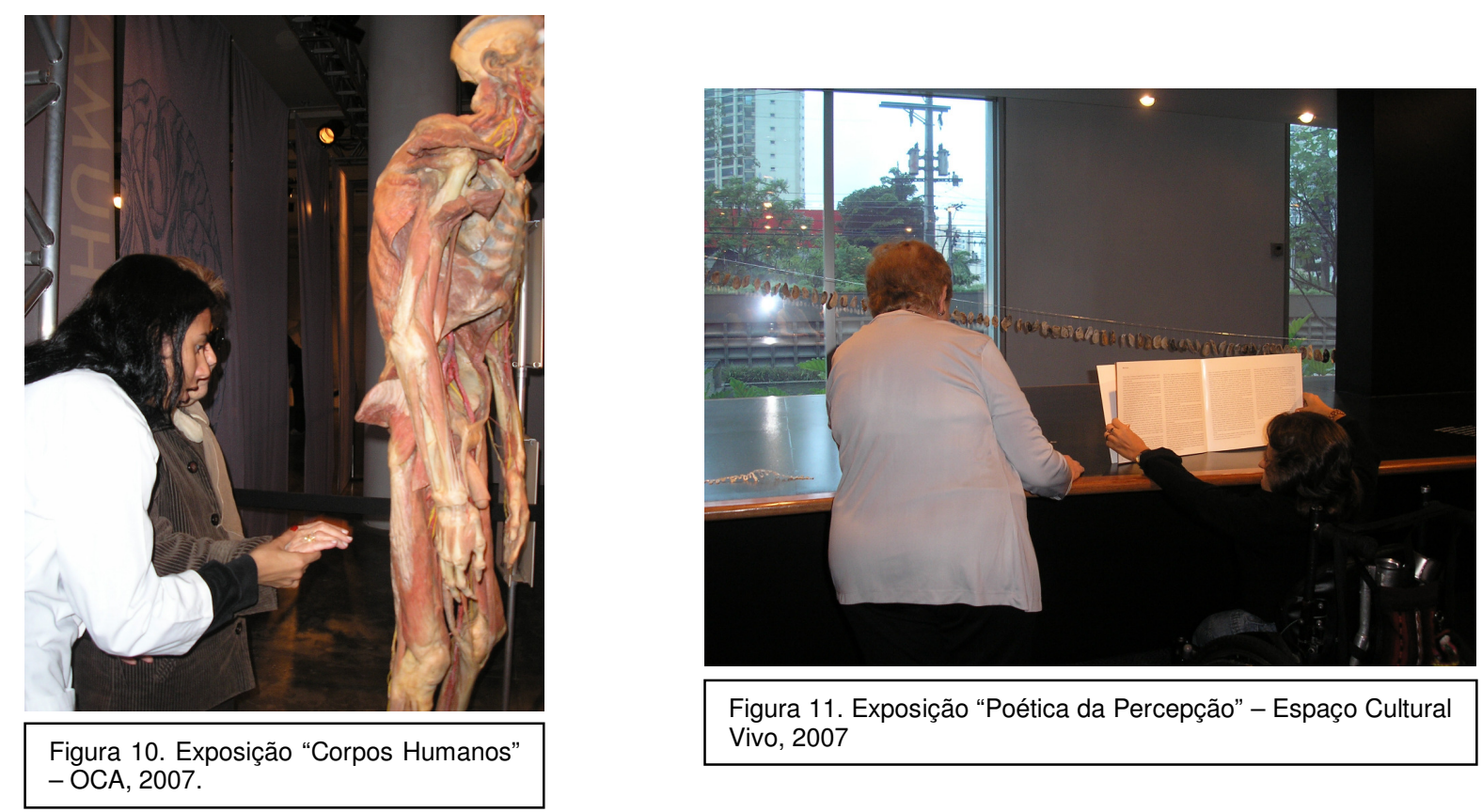

Outra situação digna de análise foi o caso da exposição "Poética da Percepção" promovida entre 2007 e 2008 pelo Instituto Vivo, pertencente à companhia de telefonia móvel Vivo, com curadoria de Paulo Herkenhoff. A exposição contava com obras de arte brasileiras dos séculos XIX a XXI que tinham algum apelo sensorial e com um projeto de expografia adaptada à pessoa com deficiência visual. Dentro do espaço da galeria foi construída uma bancada contínua onde as obras estavam dispostas; em frente ao local das obras existia uma semi-esfera em relevo para sinalizar a presença das mesmas. As etiquetas de informação das obras estavam disponíveis em braile e caracteres grandes em alto contraste. A exposição oferecia aos seus visitantes folhetos informativos seguindo os mesmos critérios das etiquetas.

A visita técnica a tal exposição foi realizada com o acompanhamento de uma pessoa com deficiência física, Leandra Certeza, jornalista e educadora e uma pessoa com deficiência visual, Marieta Boimel, professora e especialista em avaliações de 
produtos e serviços acessíveis para pessoas com deficiência visual, que expressaram diferentes opiniões e críticas em relação à proposta. De forma resumida, os principais pontos levantados foram em relação à expografia que, apesar de incentivar a independência da pessoa com deficiência visual, não era adequada para pessoas em cadeira de rodas ou com baixa estatura; a altura da bancada não seguia os parâmetros de acessibilidade expressos na Norma Brasileira de Acessibilidade. Outros aspectos também foram levados em consideração, como obras expostas em lugares inadequados (muito acima da altura padrão da população e longe da beira da bancada) dificultando o acesso tátil para a pessoa com deficiência visual. As informações contidas nas etiquetas de identificação das peças não satisfizeram a expectativa das visitantes por informações mais completas e contextuais. Com esse exemplo foi possível considerar que, mesmo desempenhando uma ação de 'responsabilidade social', a realização técnica do projeto deixou a desejar no aspecto da acessibilidade física, por não consultarem técnicos especializados e pessoas com deficiência física para avaliar a eficácia e testar o uso do mobiliário dito adequado; bem como no acesso à informação, que se restringiu a oferecer apenas as informações básicas aos visitantes, sem investir no treinamento dos profissionais de atendimento para o respeito às diferenças e para possibilitar propostas de mediação que agregassem valor ao acesso sensorial às obras expostas.

A conclusão da coleta e análise dos dados possibilita compreender alguns dos entraves e problemas em relação à efetivação de políticas culturais de acessibilidade em museus citados pelos gestores culturais entrevistados pela pesquisa. Pontos como conhecimento técnico de prestadores de serviços em relação às adequações arquitetônicas; dificuldades financeiras e burocráticas para dar continuidade aos projetos especiais e avaliação qualificada das propostas inclusivas permearam toda a análise dos casos escolhidos para ilustrar o cenário atual da área.

Em outros pontos foi possível identificar os problemas levantados pelos representantes do público alvo entrevistado, como a diversidade de ofertas de exposições e eventos culturais acessíveis, a garantia de participação plena na elaboração e avaliação dos serviços promovidos pelo museu, o respeito às diferenças 
culturais e sociais de seus visitantes e as possibilidades ilimitadas de relacionamento com os museus e exposições.

Todo e qualquer projeto ou programa, independente de seu público alvo, pode apresentar acertos e erros, independente de sua intenção. A afirmação pode ser percebida na análise aqui realizada sobre os museus e exposições visitados com o objetivo de compor a fundamentação desta pesquisa. É função dos gestores culturais e dos proponentes de projetos voltados às pessoas com deficiência, que ainda são novos no ambiente cultural, avaliar continuamente suas propostas e promover a participação dos beneficiários na avaliação real de sua eficácia.

Os fatos aqui analisados, que mereceram aprovação do público alvo e proporcionaram experiências para a área, podem ser considerados exemplos para que outras instituições desenvolvam seus projetos e para que os órgãos que administram e regulamentam a atuação dos museus criem políticas de acesso à cultura que, de fato, promovam mudanças no cenário. No entanto os fatos que receberam críticas negativas precisam de revisão por parte de seus proponentes, pois não contribuem qualitativamente com o desenvolvimento da área e com o aumento das ofertas de inclusão nos museus. Promover a acessibilidade segundo os parâmetros do Movimento de Inclusão Social é fazer com (a pessoa com deficiência) e não fazer para, pois é nesse detalhe que está o maior risco de perpetuar o assistencialismo e a discriminação. 


\section{Conclusões Finais - Considerações e subsídios sobre Políticas Culturais de Acessibilidade em Museus.}

De acordo com a bibliografia analisada nesta dissertação, com os parâmetros e conquistas do Movimento de Inclusão Social, com as declarações e documentos produzidos pelo ICOM ao longo de seu desenvolvimento depois da primeira metade do século XX, com os depoimentos de gestores culturais abertos às discussões acerca da inclusão, com os depoimentos de pessoas com deficiência que freqüentam e estabelecem relações de colaboração com museus e com a análise do cenário cultural brasileiro em relação à acessibilidade, é possível afirmar que a criação de políticas culturais de acessibilidade em museus representa uma tarefa urgente na agenda das instituições e órgãos culturais. No entanto, também foi possível identificar que existem impasses que dificultam esta proposição, inerentes à estrutura física e conceitual dos museus e ao desconhecimento da sociedade em relação à equiparação de oportunidades para as pessoas com deficiência.

Apesar do Movimento de Inclusão Social ter iniciado sua militância há mais de 25 anos defendendo a inclusão das pessoas com deficiência em todas as esferas sociais, a igualdade de direitos para essa população e a mudança social em benefício da acessibilidade, ainda existem estruturas sociais que perpetuam o atendimento especial que, por sua vez, mantêm o assistencialismo, a segregação e o entrave no desenvolvimento humano e social em relação ao convívio com as diferenças.

As pessoas com deficiência têm seus direitos constituídos em declarações, leis, normas e documentos públicos nacionais e internacionais; entretanto, tais direitos, no Brasil, permanecem atrelados ao poder das lideranças sociais que os colocam em prática de acordo com seus interesses, fazendo com que a avassaladora minoria de aproximadamente 25 milhões de brasileiros dependa da vontade política e momentos favoráveis para exercer sua cidadania.

Neste sentido, a discussão atual da função dos museus como agente de desenvolvimento social, problematizada pelo ICOM, tem como responsabilidade responder a questões como a do acesso ao patrimônio preservado pelos museus a 
diferentes públicos. Se os museus têm como atribuição atuar no desenvolvimento da sociedade e do indivíduo, como pode deixar de trabalhar pelo respeito às diferenças em seu ambiente? Como pode apresentar aos seus visitantes as diferentes culturas e manifestações de vida, arte e ciência de forma a incentivar a celebração da diversidade?

As repostas a essas questões são sempre justificadas pela carência financeira e pelas 'outras prioridades' dos museus. Mas, o que são as 'outras prioridades'? Receber um número maior de visitantes, ter mais espaço na mídia, garantir a preservação das coleções materiais por meio de planos de segurança? Tais prioridades correspondem à missão de 'agentes de desenvolvimento social'? Quantificar um grande número de visitantes significa contribuir com o desenvolvimento do indivíduo e da sociedade?

Se os museus em pleno século XXI, depois de quase 300 anos de História, enfrentam problemas em relação à sua validade social, podemos crer que precisam reavaliar sua atuação nas últimas décadas, refletindo sobre suas políticas de atração de públicos, preservação de coleções e formação de indivíduos críticos. O desenvolvimento de estratégias de mediação acessíveis às diferentes formas de locomoção, cognição e percepção contribui com o acolhimento de diversos públicos pela possibilidade de relações mais sensíveis e menos racionais com a cultura institucionalizada nos museus. Com a sensibilização social, os museus ganham mais respeito e menos objeção por parte da sociedade. Proporcionar a participação dos diferentes públicos em ações de reflexão e desenvolvimento da capacidade crítica, seja por mediações de exposições ou atividades que extrapolem o espaço físico do museu, promovendo acesso às diferentes populações, contribui para a formação de indivíduos mais críticos.

O direito de acessar os museus precisa ser garantido pela criação de políticas públicas e institucionais que possibilitem o uso dos equipamentos culturais sem barreiras de convívio, físicas, sensoriais e cognitivas. Por mais forças que possua o movimento de inclusão social, é necessária a mudança estrutural do equipamento para que os direitos do público beneficiário sejam respeitados. 
Como afirma Bauman:

\begin{abstract}
Há um grande e crescente abismo entre a condição social de indivíduos de jure e suas chances de tornar indivíduos de facto - isto é, de ganhar controle sobre seus destinos e tomar as decisões que em verdade desejam. É desse abismo que emanam os eflúvios mais venenosos que contaminam as vidas dos indivíduos contemporâneos. Esse abismo não pode ser transposto apenas por esforços individuais: não pelos meios e recursos disponíveis dentro da políticavida auto-administrada. Transpor o abismo é a tarefa da política com $\mathrm{P}$ maiúsculo." (BAUMAN, 2001 p. 48).
\end{abstract}

Isto é, para que as pessoas com deficiência se tornem cidadãos no acesso à cultura e aos museus, precisam colocar em ação seu desejo em relação às ofertas culturais; devem poder visitar os museus e exposições de sua preferência a qualquer momento, sem solicitar atendimento especial, ou ter que alertar o museu sobre sua intenção de visitá-los; devem ter o direito de ir e vir, garantido pela Declaração Internacional dos Direitos Humanos. Os museus não se tornarão inclusivos recebendo as pessoas com deficiência de forma paliativa e sem proporcionar a eliminação de barreiras de acesso para os indivíduos. Soluções imediatistas como: carregar pessoas em cadeiras de rodas pelas escadarias de entrada, permitir o acesso tátil às coleções de forma descontrolada e irresponsável às pessoas com deficiência visual, deixar de cobrar pelo ingresso do visitante por sua condição física e oferecer facilidades momentâneas e não extensivas aos demais visitantes, não contribuem com o desenvolvimento de ambientes culturais inclusivos. A inclusão de pessoas com deficiência e mobilidade reduzida não pode pressupor das barreiras enfrentadas por esses indivíduos no acesso aos museus de forma simpática e agradecida. A questão precisa ser solucionada por meio de uma nova concepção do espaço, linguagem, mediação e inserção do museu; uma nova política de atuação deve ser elaborada, onde todos os colaboradores, os parceiros, os patrocinadores, os estabelecimentos do entorno, a vizinhança, a subprefeitura, o departamento de trânsito, os funcionários dos meios de transporte público que englobam a região e outros atores sociais, recebam a informação de que aquele espaço está aberto às pessoas com deficiência e mobilidade reduzida e colaborem dentro de suas possibilidades e atribuições com a inclusão dessa população. 
$\mathrm{Na}$ realidade atual dos equipamentos culturais brasileiros esse público ainda enfrenta uma situação que pode ser considerada de natureza neoliberal.

"se as pessoas 'normais' não têm direitos, o que esperar para os 'incapacitados'” (sic). (SAID, 2003 p.91)

O desaparecimento da condição de bem-estar social significa que não existe a obrigatoriedade do poder público em garantir os direitos das pessoas. No contexto analisado, a política de atuação dos museus não é obrigada a garantir os direitos das pessoas com deficiência.

O neoliberalismo defende as oportunidades igualitárias, no entanto, cabe a cada indivíduo sustentar sua situação estável por conta própria; caso contrário, o Estado não Ihe garantirá nenhum tipo de ajuda. Os museus não impedem as visitas de pessoas com deficiência em seus espaços, no entanto, não oferecem meios para que estas pessoas os acessem sem terem opção de escolha ou passarem por situações desagradáveis.

Os direitos que deveriam ser garantidos pelo Estado às condições básicas e dignas não existem mais, fazendo desaparecer a condição de cidadãos. As adequações que deveriam ser promovidas pelos museus não são desenvolvidas, impedindo o acesso do público alvo.

Apesar de um discurso público de preocupações sociais e solidárias, o futuro se apresenta cada vez mais incerto para a maioria das pessoas, pois progressivamente os direitos tornam-se presas do mercado globalizado: o que antes era um direito torna-se nesse cenário uma mercadoria. Mesmo com a aderência à 'responsabilidade social', os museus realizam raras ações de acessibilidade para a população de pessoas com deficiência. Nesse sentido, as poucas instituições que possuem programas de atendimento às pessoas com deficiência são consideradas de ótima qualidade, sem que o público em questão acumule experiências para analisar criticamente as ofertas.

A condição de perda dos direitos desse público nos museus só será revertida a partir da crítica à afirmação de que os museus brasileiros estão contribuindo para o 
desenvolvimento social por meio de projetos de inclusão social assumida por todos os responsáveis pela conduta dos equipamentos culturais: conselhos, órgãos públicos, fóruns, eventos acadêmicos, periódicos, profissionais, meios de comunicação e a própria sociedade civil. Ou seja, o que ainda impera nessa esfera é a retórica da função social do museu, mais do que a realidade das ações de políticas culturais inclusivas.

Os museus necessitam despertar em relação à acessibilidade, tomando como referência os raros exemplos de atendimento inclusivo desenvolvidos por instituições, de forma individualizada. No entanto, o número reduzido de projetos dessa natureza apenas enuncia o desafio frente ao cenário cultural que considera as ações isoladas como projetos provenientes da solidariedade dos proponentes, perpetuando 0 pensamento assistencialista em relação à inclusão cultural de pessoas com deficiência.

Nas áreas criativas da economia que estabelecem relações próximas do ambiente dos museus, artistas e produtores culturais que trabalham com diferentes linguagens discutem as mesmas questões em suas obras e propostas de forma mais eficaz, envolvendo o espectador no questionamento em relação à diferença e normalidade. Nas manifestações culturais contemporâneas, por exemplo, a necessidade crescente do ser humano por relações que extrapolem a percepção visual tem se apresentado cada vez mais intensa, já configurando uma temática recorrente em diversas linguagens, como na literatura em obras como "A Invenção de Morel" de Bioy Casares, 1940 e "Ensaio sobre a Cegueira" de Saramago, 1998; no cinema, em filmes como "Gosto de Cereja" de Abbas Kiarostami, 1997; "O Silêncio" de Mohsen Makhmalfab, 1998 e "Crash, no limite" de Paul Haggis, 2005; no teatro, peças como "Performance Sensorial" de Thereza Piffer, 2006; nas artes visuai,s propostas como "O Espelho Cego" de Cildo Meireles, 1970 e "A Casa é o Corpo" de Lygia Clark, 1966; e na música podemos citar, principalmente, o movimento de Música Eletroacústica, que em suas apresentações explora a percepção espacial como elemento estrutural dos concertos e composições. Todos os exemplos aqui enunciados questionam de diferentes maneiras e com diferentes objetivos a visão como o sentido primordial do indivíduo. 
Um exemplo dessa afirmação pode ser encontrado no enredo da obra "A Invenção de Morel”, de Bioy Casares, que gira em torno de uma misteriosa invenção do cientista Morel. Em um devido momento, o inventor convoca seus amigos (que estariam passando uma semana de veraneio em sua llha particular que, sem os demais saberem, era o local escolhido para servirem de cobaia) para explicar o funcionamento de sua invenção e fala sobre o que ocorrerá às imagens das pessoas capturadas pela máquina:

\begin{abstract}
Uma pessoa ou um animal ou uma coisa é, diante dos meus aparelhos, como a estação que emite o concerto que vocês estão ouvindo no rádio. Se abrirem o receptor das ondas olfativas, sentirão o perfume dos jasmins que estão junto aos seios de Madeleine, sem vê-la. Abrindo o setor de ondas tácteis, poderão acariciar sua cabeleira, suave invisível, e aprender, como os cegos, a conhecer as coisas com as mãos. Mas se abrirem o conjunto de receptores, aparece Madeleine, completa, reproduzida, idêntica, não se esqueçam que se trata de imagens extraídas dos espelhos, com os sons, a resistência do tato, o sabor, os cheiros, a temperatura perfeitamente sincronizados... Congregados os sentidos, surge a alma. Era de se esperar. Madeleine estava ali para a visão, Madeleine estava ali para a audição, Madeleine estava ali para o paladar, Madeleine estava ali para o olfato, Madeleine estava ali para o tato: Madeleine estava ali. (CASARES, 1940 p. 83, 84, 85)
\end{abstract}

Neste trecho o autor revela a intenção do personagem em possibilitar que os sentidos se somem à visão para completar a finalidade da 'Invenção de Morel' em perpetuar a memória das pessoas por meio das lembranças multissensoriais.

Os questionamentos da filosofia a esse fenômeno recorrente em obras criativas podem ser exemplificados a partir do pensamento de Paul Virilio que, em seu livro 'L'art à perte de vue" (A arte a perder de vista), atenta para uma arte que explorará a 'teleobjetividade' do tempo real como uma aceleração nos espaços de percepção. Segundo o autor, esta arte precisa considerar o espaço háptico do palpável além do espaço óptico, de domínio exclusivo da visão. O autor também atentou para o fato de que, há mais de um século, Merleau-Ponty, filósofo que estudou a criação de artistas modernos, previu que no futuro aconteceria uma mudança brusca na natureza psíquica 
da arte, em que a experiência proposta não seria mais embasada nas novas tecnologias de imagem, mas em uma cegueira voluntária. ${ }^{7}$

Em 1973, Lygia Clark, artista brasileira, reconhecida atualmente como uma das principais influências da arte contemporânea, pelo conjunto de sua obra, afirmava que:

\begin{abstract}
Desenvolvendo a minha fase sensorial na "nostalgia do corpo" - em que o objeto dado ainda era um suporte - o homem encontrou seu próprio corpo nas sensações táteis. Acabou por "incorporar" o objeto fazendo-o assim desaparecer. É nesse momento que o homem assume a sua própria eroticidade: ele mesmo passa a ser o próprio objeto da sensação. O erótico vivido como "profano" e a arte vivida como coisa "sagrada" à parte, se fundem como uma experiência única. É uma tentativa de integrar a própria arte "colando-a" à vida. (CLARK, 1973 p. 159 in: Arte Brasileira Hoje)
\end{abstract}

A tendência enunciada por Virilio e presente nas criações de vanguarda também pode ser encontrada em manifestações contemporâneas ligadas à arte e à natureza dos museus. Olafur Eliasson, artista contemporâneo de origem dinamarquesa, reconhecido internacionalmente, produz propostas artísticas multissensoriais que privilegiam a participação do espectador e a transformação do espaço que recebe suas criações em lugares de permanência e acolhimento. Sua obra "Projeto de Clima" elaborada para ocupar o Turbine Hall da Tate Modern em Londres no ano de 2003, transformou o frio e distante ambiente do antigo salão das turbinas que fazia parte da usina que ali existia antes da adequação para o museu, em um espaço extremamente acolhedor, quente e iluminado, onde os visitantes sem pudor sentavam-se e deitavamse no chão para usufruir do trabalho de arte, que de fato realizou o desejo de Clark de integrar a arte à vida.

\footnotetext{
${ }^{7}$ Extraído do texto original "L'art à perte de vue". Paul Virillo, 2005 p. 34
} 

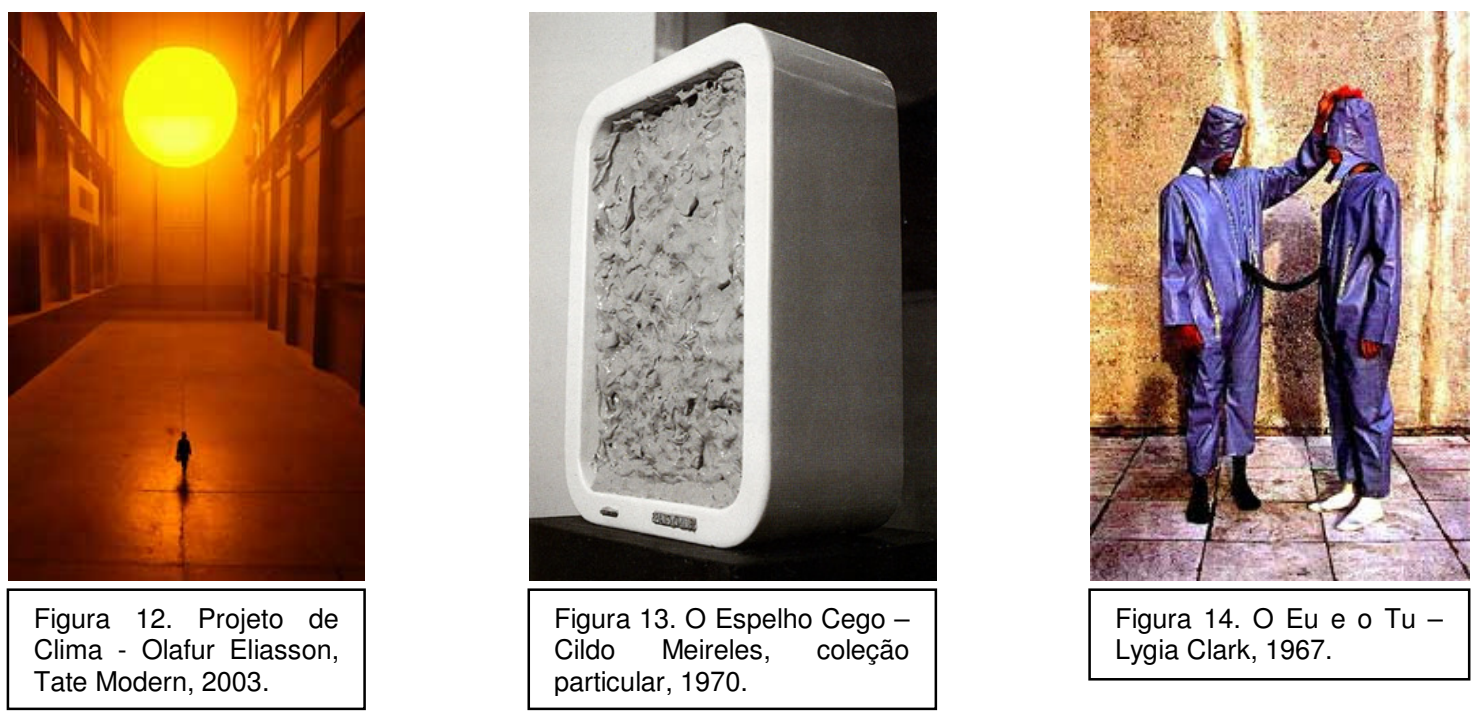

No caso dessa tendência em museus e instituições culturais, é possível citar o Museu do Diálogo, que é um espaço onde diversos ambientes são simulados para que os visitantes os percorram no escuro, sem uso da visão. O projeto foi criado em 1989 pelo filósofo e jornalista alemão Andreas Heinecke com a denominação de "Diálogo no Escuro". A inquietação do jornalista tinha origem em sua admiração por um colega de trabalho cego; na convivência com o amigo percebeu que as diferenças não impediam sua capacidade de trabalho. Decidiu criar uma forma de compartilhar o aprendizado que teve com outras pessoas, o que caracterizou como um projeto de transcendência social e um espaço para a discussão sobre a diversidade. O sucesso do projeto proporcionou uma turnê por países da Europa e logo se tornou uma empresa com diversas filiais no mundo todo. A idéia de Heinecke também influenciou a criação de jantares e atualmente restaurantes no escuro, que levam às pessoas a vivenciar experiências inusitadas no cumprimento de tarefas cotidianas desatreladas à visão. Desde 2007 o Brasil possui uma sede do Museu do Diálogo na cidade de Campinas, em São Paulo; a unidade, além da exposição que simula uma série de ambientes urbanos e domésticos a serem percorridos no escuro com orientação de um educador com deficiência visual, oferece festas de aniversário, locação do espaço para eventos e o os jantares no escuro a exemplo de outras unidades.

Os exemplos de artistas e produtores que por meio de suas inquietações em relação às diferenças e à riqueza presentes nas formas de mediação multissensorial 
criaram propostas inovadoras são de grande validade para que os museus reflitam sobre sua posição crítica em relação à manutenção da linguagem e estrutura de funcionamento baseada no modelo clássico de sedução visual e abordagem intelectual. Na dinâmica de vida contemporânea o modelo deixa de fazer sentido, já que a função atual dos museus é participar do desenvolvimento social e humano, proporcionando aos indivíduos a noção de pertencimento cultural, o exercício da capacidade crítica e o respeito às diferenças. A mudança só será possível por meio de gestões institucionais criativas que aceitem o desafio de inovar a estrutura tradicional dos museus e instituições patrimoniais e artísticas.

Com base nas constatações aqui analisadas é possível enumerar subsídios teóricos e práticos que norteiem a proposição de políticas culturais criativas de acessibilidade que agreguem valor ao desenvolvimento da área de ação cultural. Por meio das análises apresentadas ao longo da presente dissertação, é possível afirmar que políticas dessa natureza devem considerar:

1. A garantia dos direitos culturais das pessoas com deficiência, embasados por documentos, leis e pelo respeito à diversidade;

2. As conquistas do Movimento de Inclusão Social em relação à equiparação de oportunidades e à eliminação de barreiras de acesso;

3. As novas formas de relacionamento e criação multissensoriais nas manifestações artísticas e culturais e;

4. A nova atribuição dos museus como agentes de desenvolvimento social comprometidos com a inclusão social;

5. A criatividade na gestão institucional e na proposição de ações e políticas culturais inovadoras.

Tais princípios precisam integrar as discussões da área para fomentar a atuação dos museus frente à diversidade cultural. O discurso ético dos museus favorável à responsabilidade social precisa ser concretizado em ações e oportunidades efetivas às pessoas com deficiência, mobilidade reduzida e a todos os indivíduos que podem se 
beneficiar com a acessibilidade. Nesse sentido, a sensibilização dos gestores culturais em relação às diferenças, necessidades de seu público e criatividade nas ações e políticas é fundamental.

As políticas culturais, no âmbito dos museus e instituições culturais, são criadas com o objetivo de cativar novos públicos a fim de garantir sua sustentabilidade diante da situação social. Um equipamento que deixa de seguir as tendências e conquistas sociais perde a razão de existência diante de uma população que espera ser bem recebida e valorizada por sua participação no desenvolvimento econômico e social do país.

É necessário reconhecer que os museus têm se esforçado em aproximar e cativar os visitantes, primordialmente crianças e jovens, por meio de estratégias de mediação que minimizam o impacto característico de sua origem científica e elitizada. No entanto, ainda existe uma deficiência no desenvolvimento das políticas culturais, pois os agentes responsáveis por sua criação não percebem que existe uma parcela da população, que extrapola os 25 milhões de pessoas, precisa de incentivo e adequações por meio dos equipamentos para exercer seus direitos culturais. A deficiência em enxergar, escutar, relacionar-se, conscientizar-se, criar formas de relacionamento e adequar-se às necessidades das pessoas com deficiência e mobilidade reduzida representa um impasse. Mas existe um potencial de transformação que pode concretizar uma nova forma de atuação dos museus e equipamentos culturais, por meio da adequação destes espaços em benefício da inclusão social e para o incentivo à criação de propostas acessíveis a todos, independente de suas capacidades físicas, sensoriais, cognitivas, intelectuais e sociais.

Tomando como exemplo a conduta das pessoas com deficiência que buscam sua autonomia e participam de programas de reabilitação que os auxiliam na superação de barreiras físicas, sensoriais e psicológicas com o objetivo de obter êxito em sua vida pessoal e profissional, os museus precisam encarar sua necessidade de reabilitação frente ao desafio de tornar seus ambientes livres de barreiras; só assim obterá êxito na tarefa de proporcionar oportunidades para essa população e para todos os indivíduos que desejam se beneficiar do acesso aos museus. 
Referências bibliográficas

ACKERMAN, Diane. Uma História Natural dos Sentidos. 1a. ed. Rio de Janeiro: Bertrand Brasil, 1992.

ARAUJO, Marcelo Mattos; BRUNO, Maria Cristina Oliveira (org.). A Memória do Pensamento Museológico Contemporâneo: Documentos e Depoimentos. São Paulo, COMITÊ BRASILEIRO DO ICOM,1995.

ASENSIO, Mikel; SIMÓN, Cecília. The Effectiveness of communicative instruments for Blinds Visitors. Visitors Studies Conference. v.1 n.1, p. ,1996. Colorado.

BAUMAN, Zigmund. A Modernidade Líquida. $3^{\underline{a}}$ ed. Rio de Janeiro: Jorge Zahar Editora, 2004.

BAVCAR, Evgen; Tessler, Elida; Bandeira, João (orgs). Memória do Brasil. São Paulo: Cosac \& Naify, 2003.

BIOY CASARES, Adolfo. A Invenção de Morel. 3ª. ed. São Paulo: Cosac Naify, 2006.

BRUNO, Cristina. Museologia e Museus: princípios, problemas e métodos. Lisboa, Centro de Estudos de Sociologia - Universidade Lusófona de Humanidades e Tecnologias, 1997. (Cadernos de Sociomuseologia n.10).

FARIAS, Norma; BUCHALLA, Cassia Maria. A Classificação Internacional de Funcionalidade, Incapacidade e Saúde. Revista Brasileira de Epidemiologia. 8(2): p. 187-193, 2005. São Paulo.

Escritório Internacional do Museus. Carta de Atenas. CADERNOS DE DOCUMENTOS - CARTAS PATRIMONIAIS. Brasília: Ministério da Cultura - Instituto do Patrimônio Histórico e Artístico Nacional, 1995. no. 3, p. 13 a 21.

SPHAN - pró-Memória. CADERNOS MUSEOLÓGICOS. Rio de Janeiro: SPHAN - PróMemória, 1989. no. 2.

CANCLINI, Nestor Garcia. Culturas híbridas. São Paulo: EDUSP, 1998.

CANO, Begoña Consuegra. El acesso al patrimônio histórico de las persona ciegas y deficiente visuales. ONCE, 1ํㅡ edição: Madrid, 2002.

COELHO NETO, José Teixeira. Dicionário Crítico de Política Cultural. São Paulo, Editora lluminuras, 1999.

O que é ação cultural. São Paulo : Brasiliense, 1989. 94 p. (Coleção Primeiros Passos ; v. 216). 
CRIMP, Douglas. Sobre as Ruínas do Museu. Martins Fontes, $1^{\underline{a}}$ ed.: São Paulo, 2006.

DEBORD, Guy. A Sociedade do Espetáculo. Rio de Janeiro: Contraponto, 1997.

GIRAUDY, Danièle. 0 museu e a vida/ Danièle Giraudy, Henri Bouilhet; Tradução Jeanne France Filiatre Ferreira da Silva - Rio de Janeiro: Fundação Nacional PróMemória; Porto Alegre: Instituto Estadual do Livro - RS; Belo Horizonte: UFMG, 1990. 100p, il.

GONZÁLEZ DE GÓMEZ, Maria Nélida. Escopo e Abrangência da Ciencia da Informação e da Pós-Graduação da Área: anotações para uma reflexão. Transformação. n.15, p. 31-43, jan/abr. 2003.

GULLAR, Ferreira (org.). Arte Brasileira Hoje. Rio de Janeiro: Paz e Terra, 1973.

FERRARI, Aída Lúcia; CAMPOS, Elisa. De que cor é o vento? : Subsídios para ações educativo-culturais com deficientes visuais em museus. Prefeitura de Belo Horizonte, 2001. 47p.

FOUCAULT, Michel. As Palavras e as Coisas. São Paulo: Martins Fontes, 1966

FOUNDATION DE FRANCE - ICOM, MINISTERIO DE CULTURA y ONCE. Museus Abiertos a Todos los Sentidos: acoger mejor a las personas minusvalidas. Trad. Carmen Pérez Andrés e Antonia Ramos Fuentes. ONCE. Salamanca, 1994. 273p.

GROFF, Gerda. What museum guides need to know. $2^{\text {a }}$ ed. - New York: American Foundation for the Blind, 1990.

GROSSMANN, Martin. Interação entre Arte Contemporânea e Arte-Educação: subsídios para a reflexão e atualização das metodologias aplicadas. (Dissertação de Mestrado). Escola de Comunicação e Artes/ Universidade de São Paulo, 1988.

GUARNIERI, Waldisa Russio Camargo. Conceito de Cultura e sua Inter-relação com o Patrimônio Cultural e a Preservação. IBPC. nํㅜ 3, 1990,

Presença dos Museus no Panorama Político Científico-Cultural. Cadernos Museológicos. $n ²$ 2, 1989.

.Percepção e Criação. (Depoimento como Coordenadora do Projeto Museu da Indústria e da Exposição). São Paulo: Arquivo IEB-USP,1980. 
KOBASHI, Nair Yumiko e TÁLAMO, Maria de Fátima Gonçalves Moreira. Informação: fenômeno e objeto de estudo da sociedade contemporânea. Transformação. no. 15, p.7-21, set/dez. 2003.

LUSSEYRAN, Jacques. And there was light. Toronto: Little, Brown and Company, 1963.

MAJEWSKI, Janice. Part of your general public is disabled. $2^{\mathrm{a}}$ ed. Washington: Smithsonian Institution, 1993.

MARTELETO, Regina Maria e NASCIMENTO, Denise Morado. A "Informação Construída" nos meandros dos conceitos da Teoria Social de Pierre Bordieu. DataGramaZero - Revista de Ciência da Informação - v.5 n.5, outubro. 2004.

MARTUCCI, Elizabeth Márcia. Abordagem qualitativa de pesquisa em biblioteconomia: uma introdução. Ensaios APB - n. 33. 1996.

MATTOS, Marcelo Araújo; BRUNO, Maria Cristina Oliveira (org). A Memória do Pensamento Museológico Contemporâneo: Documentos e Depoimentos. Comitê Brasileiro do ICOM: São Paulo, 1995.

MERLEAU-PONTY, Maurice. O olho e o espírito. São Paulo: Cosac \& Naify, 2004.

MORAES, Denis de (org.). Por uma outra comunicação: Mídia, mundialização e poder. Rio de Janeiro: Editora Record, 2003.

MOREIRA, Conceição (et. alli). Museus e Acção Cultural. Lisboa: Universidade Lusófona De Humanidades e Tecnologias, 1996. (Cadernos de Sociomuseologia n.5).

MOUTINHO, Mario (et. alli). Sobre o Conceito de Museologia Social. Lisboa: Universidade Lusófona De Humanidades e Tecnologias, 1993. (Cadernos de Sociomuseologia n.1).

MUSAS - Revista Brasileira de Museus e Museologia. Rio de Janeiro: Instituto do Patrimônio Histórico e Artístico Nacional - Departamento de Museus e Centros Culturais, 2004 - . Anual ISSN: 1807-6149.

MUSEU DE ARTE CONTEMPORÂNEA DA UNIVERSIDADE DE SÃO PAULO. O Toque Revelador: a poética das formas. São Paulo, 1999. 38p. il.

MUSEU DA INDÚSTRIA COMÉRCIO E TÉCNOLOGIA - CENTRO SOCIAL MARIO FRANÇA DE AZEVEDO. Percepção e Criação. São Paulo, 1980.

NOWILL, Dorina. .... E eu venci assim mesmo. 1를 ed., São Paulo: Totalidade, 1996. 
RESENDE, Ricardo. MAM, o Museu Romântico de Lina Bo Bardi: origens e transformações de uma certa museografia. Escola de Comunicações e Artes Universidade de São Paulo, 2002 (dissertação de mestrado).

Projeto A expressão fotográfica e os cegos. Folder da exposição "Vistas Táteis". Secretaria de Cultura da Cidade de Londrina, 2002.

SAID, Edward. Cultura e Política. 1 ed. São Paulo: Boitempo, 2003.

SANT'ANNA, Affonso Romano de. A cegueira e o saber. Rio de Janeiro: Rocco, 2006.

SARAMAGO, José. Ensaio sobre a cegueira. São Paulo: Companhia das Letras, 1995.

SASSAKI, Romeu Kazumi. Inclusão./ Construindo uma sociedade para todos. $2^{\text {a }}$ ed., Rio de Janeiro : WVA, 1997.

SHAPIRO, Joseph P. No pity: people with disabilities forging a new civil rights movement. Three Rivers Press: New York, 1993.

TOJAL, Amanda Pinto da Fonseca. Museu de Arte e Público Especial .1999. 191p.,il., 2 anexos. Dissertação de Mestrado - Escola de Comunicações e Artes, Universidade de São Paulo, 1999.

TOJAL, Amanda Pinto da Fonseca. Políticas Públicas Culturais de Inclusão de Públicos Especiais em Museus, 2007. 322 fls.il, 1 CD-ROM. Tese de Doutorado Escola de Comunicações e Artes, Universidade de São Paulo, 2007.

VARINE-BOHAN, Hugues de. O Tempo Social. Trad. Fernanda Camargo Moro e Lourdes Rego Novaes .Livraria Eça Editora:Rio de Janeiro, 1987.

Patrimônio e Cidadania. Museologia Social. Porto Alegre: UE/ Secretaria Municipal de Cultura, 2000. 136p.

VIRILIO, Paul. L'art à perte de vue. Paris: Éditions Galilée, 2005. 


\section{Manuais}

BALTIMORE. The Center of Universal Design. The Priciples of Universal Design. Baltimore, 1997. 3p.

PORTO ALEGRE. Comitê Brasileiro do ICOM - Intenational Council of Museums. Código de Ética para Museus. Porto Alegre, 2006. 19p.

SÃO PAULO. Fundação Prefeito Faria Lima - CEPAM. Unidade de Políticas Públicas UPP. Município acessível ao cidadão. Coordenado por Adriana Romeiro de Almeida Prado. São Paulo, 2001. 276p.

SÃO PAULO. Mara Gabrilli. Desenho Universal: um conceito para todos. São Paulo, 2008. 36p.

SIDNEY. Australian Museum and The National Museum of Australia. Many Voices Making Choices: Museum audience with disabilities. Sydney, 2005. 70 p.

\section{Informacões consultadas na Internet:}

Instrução Normativa no 1. 2003. Disponível em: <http://www.iphan.gov.br>. Acesso em 04/ 2006

Censo, 2000. Disponível em: <http://www.ibge.gov.br > . Acesso 05/ 2006.

Código de ética do ICOM - International Council of Museums. Disponível em: $<$ http://www.icom.org.br>. Acesso 08/2006.

Declaração de Direitos Humanos. Disponível em: <www.onubrasil.org.br/documentos direitoshumanos.php>. Acesso em 05/2006.

Museu do Diálogo - Blog Oficial. Disponível em: <www.dialogonoescuro.blogspot.com> e no site <www.museudodialogo.com.br $>$. Acesso 08/2008.

Documentos, conceitos e notícias sobre questões ligadas a deficiência. Disponível em: $<$ http://www.saci.org.br>. Acesso em 12/07/2007.

NBR 9050 - Norma Brasileira de Acessibilidade. Disponível em < http://www.acessibilidade.org.br>. Acesso 05/ 2006.

Relato da Palestra "Comunidade e Acessibilidade", proferida por Toby Jackson, curador educativo da Tate Modern, ocorrida no Ciclo de Palestras Educação e Arte: uma experiência da Tate Modern, na Pinacoteca do Estado de São Paulo, no ano de 2005. 
Texto

completo

disponível

em:

$<$ http://forumpermanente.incubadora.fapesp.br/portal/.event pres/jornadas/educ toby/d ocumentacao/comun acessib/?searchterm=toby\%20jackson>. Acesso 03/2008.

Rede Saci - Informações gerais sobre Deficiência e Inclusão Social. Disponível em: $<$ www.saci.org.br>. Acesso em 12/06/2007. 
ANEXOS

SUMÁRIO

1. Relação de Visitas Técnicas em museus, centros culturais e exposições realizadas pela pesquisadora.

2. Questionário com carta-convite das entrevistas com gestores culturais e pessoas com deficiência.

3. Entrevistas completas dos gestores culturais e pessoas com deficiência, concedidos para esta pesquisa. 
ANEXO 1 : Relação de Visitas Técnicas em museus, centros culturais e exposições realizadas pela pesquisadora.

\section{Museus, Centros Culturais e Exposições Temporárias}

- Museu do Instituto Adolfo Lutz, São Paulo - Apresentação da exposição móvel de vírus, bactérias e doenças pesquisadas pelo Instituto. (Acompanhamento de quatro pessoas com deficiência visual)

- $\quad$ Instituto Itaú Cultural, São Paulo - Exposição 20 anos da Coleção de Arte do Itaú.

- Museu do Estado de Pernambuco, Recife - Visita à exposições de longa duração e temporárias e concepção do espaço arquitetônico acessível.

- $\quad$ Museu do Homem do Nordeste - Fundação Joaquim Nabuco, Recife - Projeto de adequações arquitetônicas para acessibilidade.

- Biblioteca SENAC Campus Santo Amaro, São Paulo - Exposição "A Célula ao Alcance das Mãos" - exposição de citologia tátil produzida pelo Laboratório de Práticas Inclusivas da UFMG. (Acompanhamento de três pessoas com deficiência visual)

- ECCO - Espaço Cultural Contemporâneo, Brasília - Exposição "O que é Normal?" Festival Brasileiro "Além dos Limites" - Programa Arte sem Barreiras da FUNARTE - MINC. (Acompanhamento de duas pessoas com deficiência visual, observação de um deficiente físico e um deficiente auditivo)

- Museu de Arte Moderna de São Paulo - Programa Igual Diferente e Projeto de Acessibilidade Arquitetônica e no Jardim das Esculturas. (Acompanhamento de quatro pessoas com deficiência visual)

- Pinacoteca do Estado de São Paulo - visita à exposição do acervo sob condução do Programa Educativo para Público Especial. (Observação de duas pessoas com deficiência visual)

- $\quad$ Museu de Arte de São Paulo - Curso de História da Arte para Deficientes Visuais. (Observação de 10 pessoas com deficiência visual) 
- Museu do Instituto Biológico, São Paulo - Visita com kits didáticos acessíveis. (Acompanhamento de uma pessoa com deficiência visual)

- Museu de Zoologia da USP, São Paulo - Visita com materiais do Projeto de acessibilidade para deficientes visuais. (Acompanhamento de 16 deficientes visuais e observação de 20 deficientes visuais)

- Museu da Bíblia de Barueri - Sociedade Bíblica do Brasil/ Prefeitura de Barueri visita com recursos de acessibilidade para pessoas com deficiência. (Acompanhamento de cinco deficientes visuais)

- Espaço Cultural Lúcio Costa, Brasília - análise da maquete de Brasília para deficientes visuais.

- Jardim Botânico de São Paulo - visita na trilha acessível e no "Jardim dos Sentidos". (Acompanhamento de dois deficientes visuais)

- $\quad$ XXVII Bienal de Artes de São Paulo - visita à exposição.

- Banco Real - Exposição "Arte em Contexto”, São Paulo - visita com atendimento especial e materiais para pessoas com deficiência visual. (Acompanhamento de três deficientes visuais).

- Instituto Vivo - Exposição "Poética da Percepção" com obras de arte com apelo sensorial e expografia adaptada à pessoa com deficiência visual (acompanhamento de uma pessoa com deficiência visual e uma com deficiência física).

- Sabina - Cidade do Conhecimento, Santo André - visita à exposição científica com ênfase na interatividade.

- Exposição "Corpo Humano" oferecida pela OCA - Parque do Ibirapuera, São Paulo - visita com orientação educativa especial. (Acompanhamento de um deficiente visual)

- Exposição "Leonardo da Vinci" oferecida pela OCA - Parque do Ibirapuera, São Paulo - visita com orientação educativa especial. (Acompanhamento de um deficiente visual)

- Instituto Tomie Ohtake - Exposição "Fluxus", São Paulo - visita à exposição de coletânea de obras dos artistas pertencentes a este coletivo com apresentação de 
obras sonoras; Exposição "Os Cinéticos" - visita à exposição de coletânea de obras de artistas nacionais e internacionais com ênfase na interação visual e sensorial.

\section{Instituições Especializadas visitadas}

- Laramara - Associação Brasileira de Deficientes Visuais, São Paulo - investigação do envolvimento da instituição com a área cultural e apresentação de departamentos ligados a desenvolvimento de produtos comunitários, educativos e tiflotécnicos.

- Instituto Padre Chico - Escola Especial de Deficientes Visuais, São Paulo investigação do envolvimento da instituição com a área cultural e artística no processo de educação e socialização de seus alunos e aconselhamento em relação à criação de um museu histórico.

- Fundação Dorina Nowill para Cegos - Centro de Memória Dorina Nowill/ Exposição "Fundação e suas muitas histórias", São Paulo - visita à exposição acessível a pessoas com deficiência visual e física. (Acompanhamento de diversos deficientes visuais, físicos, auditivos, intelectuais e múltiplos). 


\title{
ANEXO 2
}

\subsection{Carta convite e questionário para entrevista com gestores culturais.}

\author{
UNIVERSIDADE DE SÃO PAULO \\ ESCOLA DE COMUNICAÇÕES E ARTES \\ PROGRAMA DE PÓS-GRADUAÇÃO EM CIÊNCIA DA INFORMAÇÃO \\ ÁREA DE CONCENTRAÇÃO EM CULTURA E INFORMAÇÃO \\ LINHA DE PESQUISA: AÇÃO E MEDIAÇÃO CULTURAL
}

\section{Adequações para a Cultura: Acessibilidade nos Museus para as Pessoas com Deficiência: subsídios para políticas culturais inclusivas.}

Orientanda: Viviane Panelli Sarraf

Orientador: Prof. Dr. Martin Grossmann

Prezado Gestor Cultural,

O questionário abaixo integra minha pesquisa de mestrado desenvolvida na Escola de Comunicações e Artes da Universidade de São Paulo com o apoio/bolsa CAPES. O objetivo deste trabalho é levantar e analisar caminhos para a elaboração de políticas culturais de acessibilidade para pessoas com deficiências nos museus.

O resultado desta entrevista será utilizado integralmente na dissertação resultante do processo de pesquisa. Para introduzir seu depoimento gostaria de colocar uma fotografia e uma breve biografia, que apresente sua trajetória profissional e acadêmica na área dos museus. Caso seja possível solicito que forneça a imagem e alguns dados biográficos que julgue relevantes.

Além de entrevistar representantes da museologia brasileira, esta pesquisa também realizará entrevistas com freqüentadores de museus que tem algum tipo de deficiência, com objetivo de democratizar os resultados da mesma. 
Esta entrevista pode ser realizada pessoalmente ou de forma virtual (recebimento das respostas por e-mail) de acordo com sua preferência. Aguardo um retorno sobre a melhor forma de responder o questionário através do e-mail: vsarraf@gmail.com ou dos telefones (11) 3062-0555/ (11) 7631-3962.

Entrevistas Representantes da Museologia Brasileira: Investigação sobre uma política cultural acessível às pessoas com deficiência.

1. Em sua trajetória profissional e/ou acadêmica você teve oportunidade de trabalhar com pessoas com deficiências? Em caso positivo, conte um pouco sobre esta(s) experiência(s).

2. Dentro dos projetos que coordenou ou cargos que ocupou anteriormente você incentivou a realização de alguma proposta cultural/artística em benefício de pessoas com deficiência? Em caso afirmativo, exemplifique as propostas e resultados.

3. Considerando experiências estrangeiras de políticas culturais de acessibilidade para pessoas com deficiências em museus, como você analisa a condição do Brasil frente a esta realidade? Que exemplo você daria de uma prática adequada considerando os aspectos físicos, conceituais e políticos em relação à pessoa com deficiência?

4. Como a sua instituição vem tratando a questão da acessibilidade de pessoas com deficiências à Cultura e seus equipamentos? Qual seria o papel de sua instituição em ações inclusivas na esfera da Cultura, visando tornar a questão da acessibilidade uma preocupação prioritária?

Agradeço sua fundamental participação em minha pesquisa.

Viviane Panelli Sarraf 


\title{
2.2. Carta convite e questionário para entrevista com pessoas com deficiência.
}

\author{
UNIVERSIDADE DE SÃO PAULO \\ ESCOLA DE COMUNICAÇÕES E ARTES \\ PROGRAMA DE PÓS-GRADUAÇÃO EM CIÊNCIA DA INFORMAÇÃO \\ ÁREA DE CONCENTRAÇÃO EM CULTURA E INFORMAÇÃO \\ LINHA DE PESQUISA: AÇÃO E MEDIAÇÃO CULTURAL
}

\section{Adequações para a Cultura: Acessibilidade nos Museus para as Pessoas com Deficiência: subsídios para políticas culturais inclusivas.}

\author{
Orientanda: Viviane Panelli Sarraf \\ Orientador: Prof. Dr. Martin Grossmann
}

Prezado Sr. (a) Respondente,

O questionário abaixo integra minha pesquisa de mestrado desenvolvida na Escola de Comunicações e Artes da Universidade de São Paulo com o apoio/bolsa CAPES. O objetivo deste trabalho é levantar e analisar caminhos para a elaboração de políticas culturais de acessibilidade para pessoas com deficiências nos museus.

O resultado desta entrevista será utilizado integralmente na dissertação resultante do processo de pesquisa. Para introduzir seu depoimento gostaria de colocar uma fotografia e uma breve biografia, que apresente sua trajetória na área dos museus. Caso seja possível solicito que forneça a imagem e alguns dados biográficos que julgue relevante.

Além de entrevistar pessoas com deficiência que atuam direta ou indiretamente em equipamentos culturais, esta pesquisa também realizou entrevistas com representantes da museologia brasileira, com objetivo de democratizar os resultados da mesma. 
Esta entrevista pode ser realizada pessoalmente ou de forma virtual (recebimento das respostas por e-mail) de acordo com sua preferência. Aguardo um retorno sobre a melhor forma de responder o questionário através do e-mail: vsarraf@gmail.com ou dos telefones (11) 3062-0555/ (11) 7631-3962.

Entrevistas Pessoas com Deficiência em Museus: Investigação sobre uma política cultural acessível às pessoas com deficiência.

1. Em sua trajetória de aquisição de autonomia você visitou museus? Em caso positivo, conte com que objetivo?

2. Atualmente você visita museus por que razões e com que freqüência?

3. Você já foi consultado na realização de alguma proposta cultural/artística em benefício de pessoas com deficiência? Em caso afirmativo, exemplifique as propostas e resultados.

4. Considerando políticas de acessibilidade para pessoas com deficiências em outras áreas (educação, saúde, transporte, etc.), como você analisa a condição dos museus em relação às pessoas com deficiência? Que exemplo você daria de uma prática adequada considerando os aspectos físicos, conceituais e políticos?

5. Como você acha que as pessoas com deficiências devem agir para incentivar a acessibilidade nos museus e outros equipamentos culturais e qual a importância de incluir este público nessa esfera socio-cultural?

Agradeço sua fundamental participação em minha pesquisa.

Viviane Panelli Sarraf 
ANEXO 3. Entrevistas completas dos respondentes.

3.1 Entrevistas com gestores culturais.

3.1.1 Entrevista com Carlos Roberto Brandão - Presidente do Comitê Brasileiro do ICOM - International Council of Museums (cedida por e-mail)

1. Em sua trajetória profissional e/ou acadêmica você teve oportunidade de trabalhar com pessoas com deficiências? Em caso positivo, conte um pouco sobre esta(s) experiência(s).

Como Diretor do Museu de Zoologia, entre dezembro de 2001 a dezembro de 2006, tive a oportunidade de reinaugurar a mostra de longa duração do $M Z$, que estava fechada havia 3 anos e de inaugurar a galeria de exposições temporárias. Paralelamente, fizemos algumas alterações no edifício para permitir a entrada de cadeirantes, que agora, inclusive, tem acesso aos andares superiores por meio de elevador. Reservamos espaço nos pátio de estacionamento e fizemos pequenas adaptações no edifício, que não permitia esse acesso pela portaria principal, mas ao mesmo tempo está no entorno do Parque da Independência, que é tombado e não pode, portanto, sofrer alteração na fachada. Adaptamos um dos banheiros para uso de cadeirantes seguindo os critérios do CONTRU.

Ao mesmo tempo, o Serviço Educativo do $\mathrm{MZ}$ começou a desenvolver projetos para deficientes visuais, preparando maquetes dos dioramas do $M Z$ e preparando materiais específicos, que pela textura identificam tipos de animais. Esse trabalho foi realizado em parceria com a Fundação Dorina Nowill.

Também recebemos grupos de sofredores mentais, dentro de programa especial do serviço educativo. 
2. Dentro dos projetos que coordenou ou cargos que ocupou anteriormente você incentivou a realização de alguma proposta cultural/artística em benefício de pessoas com deficiência? Em caso afirmativo, exemplifique as propostas e resultados.

Esses projetos a que aludi acima são perenes e tem sido continuados pela atual gestão. Cabe lembrar que o MZ está localizado no bairro do Ipiranga, onde estão sediadas instituições que sempre se preocuparam com o assunto (como a Fundação Padre Chico que treina profissionais deficientes visuais). Essa preocupação me parece antiga, pois me recordo que sempre tivemos em nossos quadros funcionários cegos que haviam sido treinados pela Fundação. A novidade é o acesso a cadeirantes e os trabalhos especialmente desenvolvidos para portadores de alguns tipos de deficiência pelo nosso Serviço Educativo, que tive a honra e o prazer de estimular e buscar financiamento.

3. Considerando experiências estrangeiras de políticas culturais de acessibilidade para pessoas com deficiências em museus, como você analisa a condição do Brasil frente a esta realidade? Que exemplo você daria de uma prática adequada considerando os aspectos físicos, conceituais e políticos em relação à pessoa com deficiência?

Acho que é importante ressaltar que muitos museus estão abrigados em edifícios históricos que não permitem muitas das adaptações necessárias, como é o caso do museu em que trabalho. Outras vezes, tais adaptações exigiriam investimento que os museus não têm como cobrir. Ainda assim, observo que os novos projetos de museus têm levado isso em consideração e mesmo museus tradicionais têm demonstrado essa preocupação, ainda que nem sempre tenham condições de alterar as situações vigentes. Um dos maiores museus da cidade de São Paulo, por exemplo, não tem banheiros para o público dentro do edifício, nem como instala-los, por ser edifício tombado e cheio de problemas estruturais.

4. Como o ICOM - BR (International Council of Museums - Brasil) vem tratando a questão da acessibilidade de pessoas com deficiências à Cultura e seus 
equipamentos? Qual seria o papel do ICOM - BR em ações nacionais e internacionais inclusivas na esfera da Cultura, visando tornar a questão da acessibilidade uma preocupação prioritária?

O ICOM é uma organização internacional que congrega profissionais de museus e instituições. Devemos lembrar que distintos países têm políticas e legislações diferentes quanto a essa questão, o que dificulta ao ICOM recomendar tratamento uniforme da questão em nível internacional. Há uma recomendação que os museus tenham a inclusão como paradigma, mas isso inclui também a inclusão cultural da população em geral e não apenas de portadores de necessidades especiais.

Quanto ao Comitê brasileiro do ICOM, minha impressão é que a diversidade de situações no País tem impedido a adoção de políticas nacionais consistentes. Apenas na semana passada o IPHAN publicou resultados preliminares sobre o número de museus existentes no Brasil (mais de 2100), reunindo instituições tradicionais, grandes e que têm enorme afluência de público, com outras muito menores, regionais ou de cunho local, sem nenhuma capacidade de manutenção básica. A enorme maioria nem tem museólogos ou profissionais especializados, muito menos políticas explícitas de inclusão.

Devemos realizar a 1ำ reunião anual do ICOM-BR sob a nova gestão em abril de 2007 em Recife, quando o tema de acessibilidade e inclusão será discutido em mesaredonda própria, na tentativa de mapear a situação atual e sugerir ações. 
3.1.2 Entrevista com Denise Grinspum - Diretora do Museu Lasar Segall - IPHAN Minc e Diretora da Ação Educativa da 27ª Bienal de Arte de São Paulo. (Cedida por email)

1. Em sua trajetória profissional e/ou acadêmica você teve oportunidade de trabalhar com pessoas com deficiências? Em caso positivo, conte um pouco sobre esta(s) experiência(s).

A minha experiência com portadores de deficiência no âmbito profissional foi quase inexistente.

2. Dentro dos projetos que coordenou ou cargos que ocupou anteriormente você incentivou a realização de alguma proposta cultural/artística em benefício de pessoas com deficiência? Em caso afirmativo, exemplifique as propostas e resultados.

Em 2004, a Área de Ação Educativa do Museu Lasar Segall realizou um projeto com a Fundação Dorina Nowill, sob a coordenação de Viviane Panelli Sarraf. Nesta ocasião, foram feitos alguns encontros entre os portadores de deficiência visual e os funcionários responsáveis pelo atendimento do público.

3. Considerando experiências estrangeiras de políticas culturais de acessibilidade para pessoas com deficiências em museus, como você analisa a condição do Brasil frente a esta realidade? Que exemplo você daria de uma prática adequada considerando os aspectos físicos, conceituais e políticos em relação à pessoa com deficiência?

Tenho pouca experiência e pouco conhecimento sobre o assunto, mas poderia apontar como uma boa conduta àquela que inclui visitantes deficientes na rotina de normalidade de suas ações.

4. Como a Ação Educativa da 27ª Bienal de Artes de São Paulo vem tratando a questão da acessibilidade de pessoas com deficiências à Cultura e seus equipamentos? Qual seria o papel da Ação Educativa da 27ª Bienal de Artes de São Paulo em ações 
inclusivas na esfera da Cultura, visando tornar a questão da acessibilidade uma preocupação prioritária?

O Projeto educativo de $27^{\mathrm{a}}$ Bienal de São Paulo lidou com os portadores de deficiência dentro de seus programas regulares; ou seja, não estabeleceu um programa especial para esse tipo de público. Por essa razão, na equipe de monitores e supervisores, foram contratados profissionais e estudantes de Terapia Ocupacional, que puderam orientar o conjunto de monitores a receber grupos com necessidades especiais.

Por questões orçamentárias, a ação prioritária inclusiva foi o desenvolvimento do Programa Centro-periferia: como viver junto, cujo principal objetivo foi a inclusão sóciocultural de visitantes de classes socais Ce D. A questão da acessibilidade de portadores de deficiências nesse contexto, não foi considerada prioritária. 
3.1.3. Entrevista com Felipe Chaimovich - Curador do Museu de Arte Moderna de São Paulo. (cedida por e-mail)

1. Em sua trajetória profissional e/ou acadêmica você teve oportunidade de trabalhar com pessoas com deficiências? Em caso positivo, conte um pouco sobre esta(s) experiência(s).

Sim. Uma vez guiei uma visita a um grupo de deficientes de fala e/ou audição. Tive que ser traduzido, portanto a comunicação foi como para pessoas que falam línguas diferentes.

2. Dentro dos projetos que coordenou ou cargos que ocupou anteriormente você incentivou a realização de alguma proposta cultural/artística em benefício de pessoas com deficiência? Em caso afirmativo, exemplifique as propostas e resultados.

Quando fui curador da exposição “2080”, no Museu de Arte Moderna de São Paulo, incentivei a prática de jogos entre os mediadores do setor educativo e os visitantes. Sei que foi uma oportunidade criativa de se receberem os diversos grupos de pessoas com deficiência que o Museu de Arte Moderna recebe com regularidade. Desconheço com precisão os resultados, que estão descritos pelo setor educativo do mesmo MAM.

3. Considerando experiências estrangeiras de políticas culturais de acessibilidade para pessoas com deficiências em museus, como você analisa a condição do Brasil frente a esta realidade? Que exemplo você daria de uma prática adequada considerando os aspectos físicos, conceituais e políticos em relação à pessoa com deficiência?

Acredito que a legislação brasileira está impondo modificações nas instalações de edifícios destinados à cultura, que se trata de um processo gradual e possivelmente lento, mas é evidente o início das melhorias. Não tenho exemplos a citar.

4. Como o Museu de Arte Moderna de São Paulo vem tratando a questão da acessibilidade de pessoas com deficiências à Cultura e seus equipamentos? Qual seria o papel do Museu de Arte Moderna de São Paulo em ações regionais inclusivas na 
esfera da Cultura, visando tornar a questão da acessibilidade uma preocupação prioritária?

O Museu de Arte Moderna de São Paulo vem se reformando continuamente, na última década, para atender pessoas com necessidades especiais. Recentemente foi instalada uma "trilha" para bengalas de deficientes visuais, na área externa do MAM, sob a marquise. Acho que o MAM trata a questão da acessibilidade como uma preocupação prioritária. 
3.1.4 Entrevista com Maria Cristina Oliveira Bruno - Vice Diretora e Coordenadora do Curso de Especialização em Museologia do Museu de Arqueologia e Etnologia da Universidade de São Paulo. (cedida por e-mail)

1. Em sua trajetória profissional e/ou acadêmica você teve oportunidade de trabalhar com pessoas com deficiências? Em caso positivo, conte um pouco sobre esta(s) experiência(s).

A minha primeira experiência de trabalho teve início no INPS em Santos, em 1973, onde trabalhei por cinco anos (entre estagiária e concursada), no Setor de Pessoal, sob a chefia de Telma Pereira. Esta profissional, com quem aprendi tudo de melhor no que se refere à organização de trabalho, liderança, respeito profissional, é portadora de deficiência física em função de uma poliomielite na infância.

Esta convivência foi fundamental para a formação da minha índole profissional e para a compreensão de que deficiência não é sinônimo de impossibilidade. Ao longo dessa convivência e mesmo até hoje, pois os nossos contatos foram mantidos, nunca constatei qualquer situação em que a mencionada deficiência tenha sido um obstáculo para essa profissional. Ao contrário, ao acompanhar a sua carreira, observei que atuou em diversos postos que dependiam de deslocamentos e outros desafios e todos foram enfrentados.

Recentemente, já nos últimos anos no Museu de Arqueologia e Etnologia da USP, tenho como colega a Rosana Bullarar que, mesmo cadeirante, desempenha suas atividades profissionais ligadas à produção gráfica, dirige seu próprio carro e participa de atividades sociais do museu. Entretanto, tenho observado que a sua presença tem levado a instituição e seus profissionais a novas posturas no cotidiano.

Ao longo de mais de vinte anos de experiência docente, tive apenas um aluno que, por problemas de uma doença degenerativa, os seus movimentos e a sua fala ficaram comprometidos. Constatei que ele não se intimidou e continuou a sua trajetória acadêmica até a realização brilhante da tese de doutoramento, da qual também participei da banca julgadora. 
2. Dentro dos projetos que coordenou ou cargos que ocupou anteriormente você incentivou a realização de alguma proposta cultural/artística em benefício de pessoas com deficiência? Em caso afirmativo, exemplifique as propostas e resultados.

$\mathrm{Na}$ minha experiência profissional, como Museóloga na Universidade de São Paulo, sempre trabalhei em edifícios inadequados e nunca tive a oportunidade de atuar junto a especialistas em deficiências. Entretanto, desde as primeiras iniciativas museológicas no Instituto de Pré-História, procuramos não restringir o atendimento ao público, apesar das restrições da arquitetura e da pouca capacitação dos funcionários. Nesse sentido, em diversas oportunidades, participei de atividades de monitoria com deficientes físicos e mentais, no âmbito do atendimento do público infanto-juvenil escolar.

Durante os anos de 2003 a 2005, tive a oportunidade de atuar junto à Secretaria Municipal de Cultural, no âmbito da Divisão de Iconografia e Museus, para a implantação do Programa Museológico do Museu da Cidade e estimulei a criação de um Grupo de Estudos sobre Saúde Mental, com o objetivo de discutir e melhor definir a atuação desse museu junto aos portadores de deficiência. Foram meses de estimulantes discussões entre profissionais das mais variadas áreas e com experiências distintas em relação à temática referida. O enfoque principal desse GT era encontrar os caminhos para não segregar o visitante portador de algum tipo de deficiência.

Nessa mesma época, participei da orientação da Monografia de Viviane Panelli Sarraf, no âmbito do Curso de Especialização em Museologia do MAE/USP, dedicada à abordagem sobre as reciprocidades entre a acessibilidade dos museus e o ponto de vista dos portadores de deficiências visuais. Esse trabalho de orientação representou, para mim, um período de grande aprendizagem, em especial sobre a necessidade de dar voz ao portador de deficiência.

3. Considerando experiências estrangeiras de políticas culturais de acessibilidade para pessoas com deficiências em museus, como você analisa a condição do Brasil frente a 
esta realidade? Que exemplo você daria de uma prática adequada considerando os aspectos físicos, conceituais e políticos em relação à pessoa com deficiência?

Entendo que o país começa a despertar para esta questão e os museus estão inseridos neste contexto de início de despertar. Com isso, gostaria de sublinhar que ainda há estranhamento, há uma enorme necessidade de adaptações arquitetônicas, urbanísticas, legislativas, entre muitas outras. Algumas instituições têm investido nos recursos pedagógicos, como é o caso do Museu de Arqueologia e Etnologia/USP e Museu de Ciências Morfológicas/UFMG, outras se destacam pela acessibilidade explícita na ausência de barreiras arquitetônicas, e mesmo, podemos mencionar aquelas que têm incentivado o funcionamento de ateliês artísticos. Neste contexto, gostaria de sublinhar os trabalhos pioneiros de Waldisa Guarnieri na década de oitenta e de Amanda Tojal na década de noventa. Sendo que, esta última, tem desdobrado suas experiências em programas de políticas públicas estaduais.

4. Como o Curso de Especialização em Museologia do MAE-USP vem tratando a questão da acessibilidade de pessoas com deficiências à Cultura e seus equipamentos? Qual seria o papel do CEMMAE - USP em ações acadêmicas e profissionais inclusivas na esfera da Cultura, visando tornar a questão da acessibilidade uma preocupação prioritária?

O CEMMAE - Curso de Especialização em Museologia do MAE/USP, foi um programa acadêmico que funcionou entre os anos de 1999 e 2006, a partir do desenvolvimento de quatro edições. As preocupações com a questão da acessibilidade sempre estiveram presentes no âmbito das disciplinas, na programação dos seminários, nos eventos extracurriculares e na realização das visitas técnicas. Nessas edições, contamos com seminários de Amanda Tojal e trouxemos professores estrangeiros que, de forma pontual, mencionaram experiências dessa natureza. Pode-se afirmar que , embora não tenha sido um tema central, a problematização sobre a acessibilidade foi contextualizada em diferentes perspectivas no âmbito do CEMMAE. 
3.1.5. Entrevista com Mário Chagas - Coordenador Técnico do DEMU - Departamento de Museus e Centros Culturais do IPHAN - Instituto do Patrimônio Histórico e Artístico Nacional. (cedida por email)

\title{
MINISTÉRIO DA CULTURA
}

\author{
INSTITUTO DO PATRIMÔNIO HISTÓRICO E ARTÍSTICO NACIONAL - IPHAN \\ DEPARTAMENTO DE MUSEUS E CENTROS CULTURAIS - COORDENAÇÃO TÉCNICA \\ Rua da Imprensa 16 / salas 701/702 - Centro \\ 20030-120 - Rio de Janeiro-RJ
}

Rio de Janeiro, 07 de agosto de 2007.

1. Sim. Trabalhei com pessoas com deficiências por diversas vezes. No Recife, no Museu do Homem do Nordeste, desenvolvi projetos de visitas guiadas com crianças com deficiência mental e também com velhos em situação de asilo.

No Rio, no Museu Histórico Nacional, trabalhei com professores e estudantes com diversos níveis de deficiência visual em visita à exposição sobre o carnaval carioca.

2. Sim. Recentemente, no Departamento de Museus e Centros Culturais prestamos consultoria técnica museológica aos professores que estão planejando um Museu no Instituto Benjamin Constant (Escola especializada em deficientes visuais). Estamos também no DEMU/IPHAN produzindo um Caderno Técnico sobre acessibilidade. Na 
Coordenação Técnica do DEMU temos um Núcleo de Arquitetura que entre outras questões, trata dos projetos de acessibilidade nos museus.

3. Em muitos aspectos o Brasil está bastante avançado. Veja o exemplo do reconhecimento da LIBRAS. No Mestrado de Museologia e Patrimônio, onde também trabalho, há uma estudante cujo projeto de pesquisa considera a LIBRAS como patrimônio cultural brasileiro. Em outros aspectos o Brasil está se estruturando a partir das exigências legais. O que me parece importante é o desenvolvimento de uma militância por parte da sociedade civil a favor da acessibilidade universal. Se é verdade que os Museus não estavam (e muitos não estão) preparados para esse tema, também é verdade que muitos, como o Museu Histórico Nacional, por exemplo, estão trabalhando sério e realizando conquistas. O Museu Histórico Nacional, vinculado ao DEMU, recebeu prêmio de qualidade de acessibilidade.

4. O papel do DEMU é estimula o debate, a reflexão e a prática museal no sentido da democratização do acesso aos bens culturais e às instituições museológicas. A Política Nacional de Museus, lançada em maio de 2003, trabalha com as questões de acessibilidade e como indiquei está em elaboração um Caderno Técnico com o tema da acessibilidade e que será amplamente distribuído. A acessibilidade passa também por questões educativas e culturais pelo desenvolvimento de nova mentalidade. A realização desse Caderno Técnico foi iniciada através de concurso público e uma equipe de professores da UFRJ foi selecionada. Possivelmente, o Caderno Técnico estará concluído no fim de 2007 e deverá ser lançado em maio de 2008.

Registro ainda o trabalho notável da professora Liana Rubi Tereza O'Campo que desde os anos 70 trabalha com o tema da acessibilidade nos museus para pessoas com deficiências. Ela hoje está aposentada, mas foi (e é) uma das professoras especiais da Escola de Museologia da UNIRIO.

Na Escola de Museologia há também a tradição de se receber alunos com deficiência e que hoje já estão atuando no mercado de trabalhando (Ex: Museu da República e Instituto Benjamin Constant). 
3.1.6 Entrevista com Martin Grossmann - Diretor do Centro Cultural São Paulo da Secretaria Municipal de Cultura de São Paulo e Professor Titular de Ação Cultural da Escola de Comunicações e Artes da Universidade de São Paulo. (cedida pessoalmente, gravada e transcrita)

1. Em sua trajetória profissional e/ou acadêmica você teve oportunidade de trabalhar com pessoas com deficiências? Em caso positivo, conte um pouco sobre esta(s) experiência(s).

No Brasil, onde o catolicismo tem uma grande influência, nós temos uma deficiência em relação às pessoas que não são categorizadas dentro da idéia do normal ou da normalidade. Há uma tendência generalizada em esconder o que seria o problema, resguardando-o de uma necessária convivência e sociabilização. Isso está presente em nossa formação. Na escola dificilmente eu tive contato com pessoas com deficiência e até na faculdade, ainda mais se tratando de uma licenciatura em artes plásticas - artes visuais, escolha que pela natureza já afasta os cegos. Mesmo pessoas com mobilidade reduzida não eram comuns, tanto na escola como na faculdade.

O primeiro contato com uma pessoa com deficiência, foi por meio de minha irmã que conheceu, em um trajeto de ônibus para casa, um deficiente visual que era estudante do $2^{\circ}$ grau que morava perto de nossa casa, mas tinha uma condição social e econômica diferente da nossa. Minha irmã o trouxe para o nosso mundo. Meu pai era um pianista e freqüentávamos o Teatro Municipal. Tínhamos uma vida cultural razoável, mais ligada à música, em algumas ocasiões ele foi com a gente em espetáculos. Esse foi a primeiro momento que a diferença, a alteridade, entrou na minha vida.

Profissionalmente, o contato com a deficiência aconteceu de forma marcante quando, a convite da então diretora Aracy Amaral, assumi a implementação e coordenação do setor de ação educativa do MAC-USP em 1985. Na verdade, o projeto desse setor surgiu de um trabalho que desenvolvemos no final de curso de Licenciatura na área de pedagogia na FAAP, inspirado em grande parte pelo projeto educativo da Pinacoteca do Estado. O grupo que formatou esse projeto era formado por Mônica Nador, Luciana Brito e por mim. Investimos muito nessa proposta para o Museu de Arte 
Contemporânea da USP. Foi nessa época que conheci pessoas que colaboravam com o Paulo Portela na Pinacoteca como Denise Grinspum e Daniela Bousso. Era uma proposta educativa exemplar que agregou muita gente naquela época.

Entusiasmados, tomamos um passo além da Faculdade e levamos o projeto que elaboramos para a FAAP para conhecimento da então diretora do MAC-USP, Aracy Amaral, que ficou muito interessada, mas não tinha como operacionalizar financeiramente o projeto naquela ocasião, em 1983.

Em 1985 ela me convidou para implementar o serviço educativo no MAC mas não teve condição de contratar a Mônica e a Luciana. A Luciana já estava atuando como auxiliar de pesquisa da Aracy e a Mônica estava mais envolvida com sua carreira artística. No final da gestão da Aracy a Luciana veio trabalhar no serviço educativo, mas era mais como uma gerente do espaço do MAC na Cidade Universitária, onde funcionava o anexo do museu que originou a atual sede.

Na época, o modelo de museu de arte da Aracy era eurocêntrico. Ela foi de grande importância para a história MAC, pois trouxe uma sistematização que os diretores anteriores não conseguiram instituir. Ela criou um organograma que considerava não só o acervo, mas também as equipes de apoio além de curadoria e exposição e fundou um núcleo de conservação e o núcleo de ação educativa que ainda não existiam no MAC. Comecei a coordenar o setor de Arte Educação em janeiro de 1985 e a Aracy tinha um projeto de curadoria do acervo já iniciado naquele momento, com um enfoque em peças tridimensionais para atingir os mais diversos públicos, e em especial os deficientes visuais.

Ela colocou em cheque os próprios conservadores recém empossados quando trouxe a idéia do toque a uma exposição de peças tridimensionais do acervo, algo inusitado para todos os envolvidos, inclusive aos vigias do museu. Tínhamos como desafio trabalhar com esta exposição de esculturas onde todos podiam tocar e assim experienciar as obras com outros sentidos além da visão.

Para mim o desafio foi trazer ao MAC um novo público, os deficientes visuais. Fui designado pela Aracy a planejar e executar a proposta didática considerando que a exposição atenderia pessoas cegas, e desenvolver um projeto de mediação voltado 
para esse público. Entrei em contato com as instituições como o Padre Chico e a Fundação Dorina Nowill. Com certo pioneirismo, produzimos talvez o primeiro catálogo para as artes visuais em braile do Brasil, além de etiquetas das peças escultóricas em braile, ambos realizados pela Fundação Dorina Nowill.

Era premissa do educativo a idéia de complementaridade da visita na exposição com atividades práticas no ateliê. Desenvolvemos uma proposta de atelier apoiada em atividades de criação que tinham como material básico a argila, que para nossa surpresa, era, em grande parte, desconhecida deste público.

Foi uma experiência riquíssima, primeiro porque toda a nossa formação em artes plásticas era centrada na visão, e ali as linguagens, os vocabulários e códigos entraram em choque quando me deparei com a forma com que os cegos interagiam na leitura das obras. Claro que batemos cabeça, pois tínhamos em mãos e no nosso repertório uma série de manuais da história da arte e da percepção, mas que infelizmente eram incompletos ou incapazes de se relacionarem ao universo da não-visão.

Éramos jovens e não havia literatura nessa área ou recursos específicos para lidar com isto. Foi muito intuitivo e desafiador, ao mesmo tempo em que demandava um grande envolvimento, pois a interação entre esses dois mundos era exigida a todo instante. Do ponto de vista pessoal o entendimento ou reflexão mais consciente desse processo começou a tomar forma depois de alguns anos quando fiz um relatório sobre a experiência no final da gestão da Aracy Amaral.

No entanto, o impacto desse primeiro envolvimento profissional com a alteridade só foi amplamente explorado durante o doutorado na Inglaterra entre 1988 e 2003, quando escrevi um artigo para uma revista acadêmica inglesa. Esse artigo comparou essa experiência do MAC-USP com uma exposição tridimensional do acervo da Tate Gallery que ocorreu em sua filial em Liverpool,. Nessa exposição, a grande contradição era que o toque nas obras era feito com luvas. Éramos obrigados a "colocar lentes no tato" ou macular o tato. Ali tomou forma uma consciência crítica do monopólio da visão sobre os outros sentidos. O artigo foi muito prazeroso de escrever, pois comecei a lidar com a língua inglesa e suas expressões idiomáticas o que acabou revelando a 
submissão da língua a esse poderio da visão. Essa foi sem dúvida a experiência mais marcante com a alteridade até hoje.

2. Dentro dos projetos que coordenou ou cargos que ocupou anteriormente você incentivou a realização de alguma proposta cultural/artística em benefício de pessoas com deficiência? Em caso afirmativo, exemplifique as propostas e resultados.

Eu volto à mesma casa em que iniciei minha carreira, o prédio da Bienal e em particular o MAC. A experiência primeira que tive no MAC foi fundamental, pois me marcou muito. Teve esta experiência na Inglaterra, em Liverpool, que foi uma experiência muito importante na minha formação profissional. Foi uma experiência única em minha trajetória fazer 5 anos de doutorado em uma faculdade de arquitetura onde eu dei aula e fui assistente em algumas disciplinas e pude desenvolver uma pesquisa muito profunda. O principal, entretanto era a minha pesquisa.

Meu artigo surge então como uma crítica à exposição da Tate amparada pela leitura do livro de Jacques Lusseyran "And There Was Light", motivada, por sua vez por uma citação encontrada em McLuhan em um dos últimos livros que ele escreveu, Laws of Media: The New Science de 1988

Nessa citação, Lusseyran afirma que objetos inanimados têm vida, ou reagem a vida. Como cego, ele afirma que ao pressionar o tampo de uma mesa, há uma contrareação do objeto. No mundo das coisas essa relação existe, certamente de uma maneira alegórica ou metafórica. Na construção de sentidos isto está na base.

Inspirado pelo McLuhan eu fui atrás do Lusseyran. A leitura dessa autobiografia causou-me forte impacto e certamente uma saudável interferência na minha "visão de mundo". Outra experiência da mesma magnitude foi visitar a casa-museu de Sir John Soane em Londres, uma casa construída na passagem do século XVIII para o XIX. É um museu para os vários sentidos, uma experiência total e imersiva: ele queria fazer uma obra de arte total, como Wagner dizia da ópera. Essa casa foi desenhada para ser uma espécie de labirinto para viver. A imersão acontece de fato, pois o que guia sua percepção é a síntese e não a análise. O que o museu geralmente faz é separar as coisas em tempo e espaço com diferentes segmentos e épocas, lá é uma experiência 
única, como no cotidiano, estar sempre convivendo com a arquitetura, com o entorno, com os ambientes e seus fluxos. A idéia maluca de Soane era que a convivência na casa iria criar, gerar arquitetos "naturalmente", o projeto que motivou esse arquiteto foi o de formar uma casta de arquitetos iniciando com seu filho, projeto esse que não deu certo logo com seu próprio filho. Então ele doou a casa para a cidade, com a condição que não sofresse alterações, então é uma casa-museu que parou no tempo. É o tipo de experiência que você não esquece jamais. Essa experiência e a leitura do Lusseyran eu coloco no mesmo nível.

E aí sim quando eu volto para o Brasil em 1998, sou convidado pelo Teixeira Coelho para participar do conselho do MAC, e logo em seguida em uma eleição do conselho sou indicado como vice-diretor. Então volto a casa para mais um período de muito trabalho e muitas realizações, que aconteceram de 1998 a 2002. Neste momento eu já tinha contato com a Amanda Tojal, ela já tinha me procurado, pois estava fazendo seu mestrado e o projeto da época da Aracy Amaral serviu como base para o programa que ela desenvolveu no MAC para pessoas com deficiência. Foi muito importante estar na diretoria do MAC e poder acompanhar de perto e valorizar o projeto comandado pela Amanda que tem sido considerado como exemplar no campo dos museus de arte, e se hoje não está mais no MAC, infelizmente, está na Pinacoteca do Estado, gerando outras reverberações. Ela levou este trabalho para todo o Brasil apresentando seus resultados em congressos, oficinas, possibilitando assim não só a sua divulgação como também ricas trocas com diferentes profissionais e pessoas envolvidas nesse campo.

3. Considerando experiências estrangeiras de políticas culturais de acessibilidade para pessoas com deficiências em museus, como você analisa a condição do Brasil frente a esta realidade? Que exemplo você daria de uma prática adequada considerando os aspectos físicos, conceituais e políticos em relação à pessoa com deficiência?

É meio complicado, pois a base, o contexto é uma sociedade católica. Cito um trabalho do Antoni Abad em Barcelona que é o encontro destas questões numa cidade fortemente ancorada na fé católica. O projeto deste artista foi o de propor aos cadeirantes desenvolver um mapeamento da cidade não por seus atributos turísticos, 
artísticos e estéticos, mas pelos nós, pela inacessibilidade. Os cadeirantes fizeram um mapa com este conteúdo. É o outro lado da moeda, pensando em Foucault, é o universo daqueles que foram rejeitados, dos renegados. Ao contrário do lluminismo que fala do conhecimento voltado para as idéias que se revelam pela luz, não a luz material ou metafórica, mas a luz que é dada pela visão, o caminho é iluminado pelos que tem a visão. O Lusseyran é interessante, pois dá uma outra leitura para a luz, uma luz espiritual, não material, uma luz que traz o entendimento de outra dimensão ao conhecimento.

No Brasil, com essa herança católica isto é difícil. Quando falamos de iluminismo isto está atrelado à religiosidade e a tradição. Nós somos mais mediterrâneos que nórdicos se pensarmos na produção européia no país. Indubitavelmente nossa cultura tem como base à cultura européia, sendo assim a visão é fundamental, central em nossa percepção. E como somos mais mediterrâneos do que nórdicos o pragmatismo não é nosso forte. Mesmo na leitura objetiva das leis e da execução delas, há uma dificuldade em aplicar as leis, seria talvez um sistema legislativo deficiente, as leis são bem feitas, mas não são aplicadas. Na Europa essa distancia entre as leis e a aplicação é bem menor. Eles estão mais adiantados que nós do ponto de vista institucional e de estabilidade política, isso permite certamente um entendimento maior das diferenças e de suas necessidades. O politicamente correto vem do universo anglosaxônico bem como o feminismo e o direito das minorias que tem como epicentro a Europa e Estados Unidos. Estes dois pedaços de mundo estão no hemisfério norte. $O$ Oriente também tem dificuldades com estas questões, mas o Japão, por exemplo, tem um serviço público muito eficiente.

Isso tem que ser levado em consideração no quadro comparado com as iniciativas estrangeiras. Sua pesquisa tem mostrado isso. No caso de políticas culturais inclusivas não podemos deixar de lado que estamos ainda enfrentando um período de instabilidade institucional no campo da cultura. Talvez agora estejamos começando um processo de maturidade institucional em políticas culturais. No Fórum Permanente nós vemos muito bem como isso ainda é um problema no Brasil principalmente por sofrer conseqüências da instabilidade da esfera pública, advindas principalmente das 
mudanças políticas. Por outro lado, as instituições privadas, mesmo que mais estáveis, ainda padecem de um maior entrosamento com a realidade brasileira.

Continuamos a vivenciar uma crise das instituições, mas hoje já podemos considerar que a estrutura cultural é uma indústria, cresceu muito, é geradora de empregos e novos mercados e está abrindo caminhos. Se a acessibilidade ainda não está no centro das políticas culturais, é em grande parte por restrições financeiras. As instituições mal têm condições de pagar seus funcionários e limpeza quiçá recursos para a acessibilidade.

Estamos comparativamente defasados, mas não quer dizer que não somos capazes, aí é uma outra história. Não tenho duvidas que temos capacidade para desenvolver excelentes projetos. Existem projetos interessantes lá fora que devem servir como base. A Tate não pensa só em mediação e adequação do espaço físico, mas em projetos que envolvem outros agentes além dos educadores como artistas no tratamento de acessibilidade para que a acessibilidade não fique só em um campo técnico, mas que de fato consiga estabelecer a passagem da questão do espaço para o ambiente. Se esses ambientes considerarem todos os sentidos já é um grande passo. Considerando não só nossa herança cultural mas casos nas artes plásticas recentes como Lygia Clark, Hélio Oiticica e Amélia Toledo, estes já apontam e abrem possibilidades de trabalho não só para visão, mas para os outros sentidos.

4. Como o Centro Cultural São Paulo está aplicando as diretrizes de uma política cultural acessível às pessoas com deficiências em sua atuação? De que forma a instituição implementa ações para que a acessibilidade de pessoas com deficiências, em seu universo, seja uma preocupação constante?

Assumi o CCSP oficialmente em setembro de 2006. O convite do secretário Carlos Augusto Calil veio em julho daquele ano. Ao aceitar passei a ficar grande parte do meu tempo neste espaço e desde então investi meu tempo em reuniões de trabalho. Uma das primeiras ações que investi foi conhecer todas as equipes. O CCSP é um espaço de 50.000m2 com mais de 400 funcionários contando os terceirizados e, além disso, tem todo um grupo que cumpre as horas extras, os convocados e uma boa 
porcentagem de funcionários públicos de outras unidades da prefeitura. É um equipamento cultural, mas é também uma cidade, uma máquina cultural por todas as características singulares: um prédio de desenho horizontal, que tem camadas e transparência muito presentes.

Em minha analise, depois de conhecer as várias equipes e o dia-a-dia da instituição só adicionou a impressão que o CCSP é um espaço único com uma arquitetura incrível que facilita a participação e interação, sua composição institucional é extremamente segmentada, e isso me inquietou muito, o fato, por exemplo, da biblioteca atuar separadamente do resto das atividades culturais, a pesquisa que trabalha da mesma forma desde a época de sua criação antes mesmo da inauguração do prédio. Em grande parte o CCSP foi organizando seguindo a fórmula eurocêntrica de cultura que divide em áreas duras a programação: artes cênicas, cinema, música, artes plásticas, bibliotecas. Então toda essa equipe convive em um universo segmentado que por mais que a arquitetura facilite por sua transparência, no dia-a-dia, no âmbito da operacionalização de uma política cultural ela se dá de forma precária, incompleta. Isso ficou ainda mais claro na biblioteca: fisicamente elas estão separadas, apesar de serem um conjunto. A biblioteca geral Sergio Milliet que é uma extensão da Biblioteca Mário de Andrade, uma de arte e cultura Alfredo Volpi, uma discoteca, uma gibiteca, e uma Biblioteca Braille, que além de biblioteca é uma editora, que produz livros em braile e falados.

As bibliotecas estão também separadas nessa arquitetura: de um lado, ao sul, próximo às rampas a Milliet e a Volpi e do outro lado do prédio, na ala norte, a gibiteca e a braile, que também estão fisicamente separadas por um jardim interno.

A gestão do espaço público e cultural é um ponto fundamental nessa gestão: não só do ponto de vista da cultura material, mas também na parte conceitual e suas aplicações na virtualidade. Desejo que o CCSP esteja aberto e receptivo aos vários públicos, não só no próprio prédio, mas também no universo da internet, adequando inclusive o site para públicos com deficiência. Estamos trabalhando para que os usuários do CCSP possam acessar a internet gratuitamente, garantindo um acesso à informação em todos 
os níveis possíveis. A presença da Braille no complexo do CCSP é interessante pois ela motiva a acessibilidade ainda mais.

Nesse momento ela simboliza o que o CCSP vive atualmente, pois está isolada. O acesso e a sinalização são feitos diretamente pelo metrô, só ali que há as guias, não há outra sinalização para o restante do prédio. Os usuários e funcionários cegos entram e ficam lá o dia todo, quem quer ter contato com eles deve ir ate lá.

O cego se quiser tomar um café na lanchonete ou conversar com colegas de outra área tem que vir acompanhado. Há toda uma serie de empecilhos para a integração, isso que me motivou a trazer a acessibilidade para o centro da política cultural que estamos desenvolvendo nestes dois anos de gestão, que vai até as eleições para prefeitura em 2008. A acessibilidade vai servir como um mote para a transformação espacial em curso. Pretendemos tornar o CCSP não só acessível para o público com deficiência, mas também metaforicamente. Com essa experiência passada acho que isso estará bem calçado conceitualmente.

Para tanto precisamos contar com acessoria externa, como já temos da Fundação Dorina Nowill, da Fundação Lara Mara, e da SEPED que por meio de sua CPA - Comissão Permanente de Acessibilidade, já tinha realizado um relatório de acessibilidade e que foi atualizado recentemente. No ano passado reservamos uma verba inicial do orçamento de 2007 de $R \$ 100.000,00$ para fazermos as adequações mais significativas no espaço do CCSP esse ano.

Temos pensado a programação com uma nova divisão de curadoria, que é uma fusão da pesquisa com a programação e com isso pretendemos que os curadores pensem em propostas integradas. O festival de férias em janeiro de 2007 é a primeira experiência desta área que congrega até a biblioteca em sua grade. Para o mês de março estamos fazendo uma programação voltada para as mulheres que se chama Lilás: mulheres de todas as artes, que aborda o papel da mulher em nossa cultura. Um outro tema ou foco que queremos trabalhar é o da acessibilidade, e sabemos que trabalhar com a esfera publica é sempre complicado para a continuidade de uma política cultural. Mas no mínimo queremos deixar não um projeto político e sim um 
projeto de renovação institucional e não tenho dúvidas que a acessibilidade está no centro desse processo. 
3.1.7 Entrevista com Ricardo Resende, pesquisador da área de artes visuais e exDiretor do Museu de Arte Contemporânea do Ceará - Centro Cultural Dragão do Mar Fortaleza. (cedida por email)

1. Em sua trajetória profissional e/ou acadêmica você teve oportunidade de trabalhar com pessoas com deficiências? Em caso positivo, conte um pouco sobre esta(s) experiência(s).

A minha iniciação na museologia se deu pelo serviço educativo do Museu de Arte Contemporânea da Universidade de São Paulo e pude acompanhar as primeiras experiências de uma colega de setor, Amanda Tojal, que acabou por especializar-se em público de museu portador de alguma deficiência física ou mental. Foi nesta ocasião que dei minhas primeiras visitas guiadas para este público e conseqüentemente me despertaram para a problemática da acessibilidade nos edifícios e serviços dos museus.

A lição principal que levo desta experiência, é que não devemos nunca subestimar a capacidade de expressão, comunicação e ação de seres humanos ainda mais possuidores de alguma deficiência. $O$ educador deve entrar com a sensibilidade para conduzir a visita: sem ser assistencialista ou emotivo, o profissional deve agir naturalmente passando confiança e conhecimento.

Um segundo momento foi por ocasião da reforma do Museu de Arte Moderna de São Paulo em 1995/96 quando tive um embate direto com o escritório de arquitetura responsável e que não previa até ali as facilidades para os deficientes físicos. Algumas soluções "paliativas" foram encontradas diante da "descoberta" deste "outro mundo" por aqueles que não estão acostumados a pensar nestes usuários ao proporem seus projetos. A entrada de usuários de cadeiras de rodas acontece ainda hoje pelo restaurante do museu em meio a mesas, cadeiras e pessoas comendo. Constrangedor para ambos!

Encontrei também dificuldade ou resistência, junto à presidência e direção da mesma instituição na disponibilização de cadeiras de rodas em local visível logo à entrada do museu. As alegações foram desde um "incômodo" em se deparar com a realidade do 
problema que as cadeiras significavam em sua visão plena, até uma certa dose de preconceito.

Um terceiro momento marcante foi quando fui chamado para ouvir e acalmar diante de suas reclamações acaloradas, um visitante que tinha sérias dificuldades de locomoção e encontrava-se indignado diante da falta de rampas para adentrar-se ao museu, no Parque Ibirapuera. Este senhor indignado e com razão, exigia os seus direitos à vagas reservadas no estacionamento entre outras facilidades que ainda não dispúnhamos. Isto me levou até a prefeitura do município atrás da legislação e orientação para a implantação dessas facilidades, colocando a instituição sob pressão de estar irregular. O banheiro diante de falta de planejamento encontra-se em pleno espaço expositivo.

2. Dentro dos projetos que coordenou ou cargos que ocupou anteriormente você incentivou a realização de alguma proposta cultural/artística em benefício de pessoas com deficiência? Em caso afirmativo, exemplifique as propostas e resultados.

Neste meio tempo organizarmos no Museu de Arte Moderna de São Paulo, uma mostra de esculturas com a Fundação Dorina Nowill Para Cegos. Editamos um catálogo e etiquetas em braile. Os educadores foram preparados pela fundação, organizamos encontros para discussão da efetivação do projeto e tivemos acesso ao mailling de outras instituições e escolas que tinham em seus quadros alunos com deficiência visual. O resultado, devo confessar, não foi suficientemente estudado e nem virou uma ação rotineira do museu. Infelizmente, estas iniciativas necessitam ou solicitam mais tempo para elaboração e execução, pois requerem cuidados extras. Na estrutura que nos era colocada na época, o Serviço Educativo estava muito centralizado em minha pessoa e não contava na minha equipe (estagiários) com educadores de carreira e pesquisadores.

Estas iniciativas deveriam ser uma prática constante nas instituições museológicas, no entanto são eventuais.

3. Considerando experiências estrangeiras de políticas culturais de acessibilidade para pessoas com deficiências em museus, como você analisa a condição do Brasil frente a 
esta realidade? Que exemplo você daria de uma prática adequada considerando os aspectos físicos, conceituais e políticos em relação à pessoa com deficiência?

Entendo que estamos bastante atrasados na execução das leis (as nossas leis existem e são bastante abrangentes e generosas), no entanto na prática não funcionam por descaso das autoridades que não fazem prevalecer os direitos dos cidadãos (e não só os dos portadores de deficiência, mas os dos idosos, das crianças, das mulheres e assim por diante).

Vejo o problema agravado nos museus que na maioria são prédios adaptados e, portanto, não preparados originalmente para receber estas pessoas. O custo da adaptação desestimula as instituições diante da falta de recursos garantidos pela iniciativa pública para a manutenção e reforma desses prédios.

Fica difícil ter exemplos bem sucedidos mesmo em museus construídos recentemente. O Museu de Arte Contemporânea de Niterói, inaugurado em 1997, conta com uma rampa inumana a ser vencida por quem se propõe a visitá-lo (estava previsto por ocasião de minha última visita, um elevador que para chegar até ele existia uma escadaria...). Projeto de Oscar Niemayer em final do Século XX!

4. Como o Museu de Arte Contemporânea do Ceará vem tratando a questão da acessibilidade de pessoas com deficiência à Cultura e seus equipamentos? Qual seria o papel do MAC - Ceará em ações regionais inclusivas na esfera da Cultura, visando tornar a questão da acessibilidade uma preocupação prioritária?

O Museu de Arte Contemporânea do Centro Dragão do Mar de Arte e Cultura é um projeto ainda mais recente que o carioca, é de 1999 e conta apenas com um elevador panorâmico que nunca funciona por problemas técnicos.

Para um deficiente em cadeira de rodas o acesso de um andar para o outro no museu só se dá atualmente pelo elevador de cargas!

Este elevador "oficial" está para ser mudado em breve.

Mas o problema é mais grave no Centro Cultural como um todo. Um projeto de 28.000 m2 de área ocupada e 14.000 m2 de área construída, conta com poucos e difíceis acessos em seus diversos equipamentos e níveis. Nos cinemas e teatro, só por 
escadas para se chegar as salas de espetáculo. O mais incrível é pensar que estes projetos que tomo como exemplo, são de final da década de 90. Ou seja, construções muito recentes sem a preocupação esperada diante dos avanços se compararmos com países do dito primeiro mundo. Temos muito que mudar, principalmente na nossa forma de pensar os direitos do outro não só aqui no Ceará, mas no Brasil como um todo. As instituições culturais deveriam tomar a frente e se tornarem exemplo de soluções para a sociedade.

Ricardo Resende 
3.1.8 Entrevista com Sílvia Antíbas Diretora do DEMA - Departamento de Museus e Arquivos da Secretaria Estadual de Cultura de São Paulo. (cedida por telefone, gravada, transcrita e aprovada)

1. Em sua trajetória profissional e/ou acadêmica você teve oportunidade de trabalhar com pessoas com deficiências? Em caso positivo, conte um pouco sobre esta(s) experiência(s).

Trabalhei na Secretaria Estadual de Cultura com Guilherme Bara que é deficiente visual, não tive nenhuma dificuldade em trabalhar com ele, pois era uma pessoa muito adaptada. No início sempre é um desafio pela falta de experiência nesta convivência no trabalho. Mas com o tempo a convivência se tornou natural.

Eu até me esquecia da sua deficiência visual e várias vezes perguntava "você não está vendo tal coisa?" E ele me respondia brincando que não podia ver nada...

2. Dentro dos projetos que coordenou ou cargos que ocupou anteriormente você incentivou a realização de alguma proposta cultural/artística em benefício de pessoas com deficiência? Em caso afirmativo, exemplifique as propostas e resultados.

Trabalhei no Depto de Formação Cultural da SEC-SP (Secretaria de Estado da Cultura de São Paulo), neste cargo promovia oficinas culturais para pessoas com todos os tipos de deficiências. Já existia um orçamento previsto dentro do departamento, específico para estas Oficinas Culturais, onde os profissionais eram contratados. Contávamos com uma parceria na parte conceitual das instituições especializadas, já que não possuíamos profissionais especializados em acessibilidade dentro de nossa equipe.

3. Considerando experiências estrangeiras de políticas culturais de acessibilidade para pessoas com deficiências em museus, como você analisa a condição do Brasil frente a esta realidade? Que exemplo você daria de uma prática adequada considerando os aspectos físicos, conceituais e políticos em relação a pessoa com deficiência? 
Acho que posso falar melhor do Estado de São Paulo, que é o foco de meu trabalho no DEMA (Departamento de Museus e Arquivos). Acho que ainda estamos engatinhando, as pessoas estão começando a pensar em acessibilidade como uma nova possibilidade. No entanto faltam condições não só financeiras, mas técnicas de trabalhar com isto. Fico muito satisfeita ao ver os grandes museus trabalhando com esta questão. Além dos museus do DEMA percebo que outros grandes museus brasileiros como o MAM-SP também possuem programas e iniciativas de acessibilidade.

Nem todas as iniciativas estão acertando, mas isto é um processo a ser amadurecido teórica e praticamente. O que acontece em alguns casos é que não existe uma união entre a prática e a teoria, isto é, nem todos os trabalhos seguem um mesmo padrão de qualidade.

Recentemente, em uma visita, tomei conhecimento do trabalho de acessibilidade que o Museu de Arte Brasileira da FAAP está realizando nesta exposição de Arte da Grécia. Como exemplos posso citar o trabalho da Pinacoteca do Estado de São Paulo, que tem muita qualidade e o Centro de Memória da Fundação Dorina Nowill para Cegos, o qual me surpreendeu.

4. Como o Departamento de Museus e Arquivos DEMA - SEC-SP está aplicando as diretrizes de uma política cultural acessível às pessoas com deficiências em sua atuação? De que forma a instituição implementa ações para que a acessibilidade de pessoas com deficiências, em seu universo, seja uma preocupação constante?

Estamos ampliando o projeto da Pinacoteca do Estado para três museus da capital e dois do interior, pegando todo o know-how da equipe da Pinacoteca e o mesmo patrocinador, no caso o Cartão Visa. É um projeto com duração de dois anos, onde museus importantes do interior como $O$ Museu Portinari em Brodósqui, serão contemplados.

Acho muito importante trabalhar com a acessibilidade também no interior de São Paulo e neste sentido além de ampliar o projeto de acessibilidade nos museus também oferecemos um curso de formação sobre acessibilidade em museus, com os 
profissionais da Pinacoteca, em algumas regiões do interior paulista, abrindo vagas para servidores públicos de museus e outros profissionais ligados às áreas de saúde, esportes, educação.

Acredito que o tema da acessibilidade atualmente deixou de ser uma questão apenas de legislação, podemos considerar que os museus estão mais abertos à inclusão de pessoas com deficiências. Os trabalhos de acessibilidade em museus são muito mais comuns atualmente do que há algum tempo atrás.

Penso que quase todos os museus estão atentos para esta questão, consideram a acessibilidade em sua atuação. Mas percebo que isto não é uma questão presente apenas nos museus, mas em outros equipamentos culturais como cinemas, teatros e outros. 


\subsection{Entrevistas com Pessoas com Deficiência que freqüentam museus.}

3.2.1 Entrevista com Antônio Carlos Grandi, deficiente visual, professor de informática e representante dos Conselhos Municipal e Estadual para a Pessoa com Deficiência de São Paulo. (cedida por e-mail)

1. Em sua trajetória de aquisição de autonomia você visitou museus? Em caso positivo, conte com que objetivo?

Sim. A partir do convite da Sra. Viviane, passei a integrar o grupo de deficientes visuais, para visitar alguns museus da Capital, com o objetivo de avaliar as condições de acessibilidade dos mesmos.

2. Atualmente você visita museus por que razões e com que freqüência?

Sim. No ano passado visitei duas exposições, tendo uma delas algumas obras adaptadas ao deficiente visual. Se existissem mais exposições e museus adaptados ao deficiente visual, certamente eu os visitaria com maior freqüência.

3. Você já foi consultado na realização de alguma proposta cultural/artística em benefício de pessoas com deficiência? Em caso afirmativo, exemplifique as propostas e resultados.

Sim. Nas visitas em que participei com o grupo, demos várias sugestões para melhorar a acessibilidade aos museus visitados, desde a orientação e treinamento dos monitores, acesso às dependências do museu, orientação espacial do cego, disponibilização de réplicas das obras mais significativas quando as mesmas não podem ser tocadas, guias ou cartilhas em Braile ou em áudio, etc.

4. Considerando políticas de acessibilidade para pessoas com deficiências em outras áreas (educação, saúde, transporte, etc.), como você analisa a condição dos museus em relação às pessoas com deficiência? Que exemplo você daria de uma prática adequada considerando os aspectos físicos, conceituais e políticos? 
Assim como nas demais áreas citadas, ainda são incipientes as ações que visem melhorar a acessibilidade das pessoas deficientes. Existem alguns exemplos pontuais destas ações, podendo citar como exemplo, o museu de Zoologia de São Paulo, onde foram criadas maquetes que representam diferentes ecossistemas brasileiros, com as plantas e animais mais representativos destes ambientes.

5. Como você acha que as pessoas com deficiências devem agir para incentivar a acessibilidade nos museus e outros equipamentos culturais e qual a importância de incluir este público nessa esfera sócio-cultural?

A verdadeira inclusão da pessoa deficiente parte do princípio da democratização do acesso facilitado a todos órgãos públicos e privados, como escolas, parques, bancos restaurantes, exposições, museus, etc.

Através das associações e entidades de pessoas com deficiências, cobrar das autoridades competentes, que os diferentes equipamentos públicos, sejam adaptados e acessíveis a todas as pessoas, deficientes ou não.

As pessoas com deficiências têm os mesmos direitos ao acesso a cultura, ao esporte, ao lazer e atendimento médico que as demais pessoas, ou seja, tem o direito a exercer a cidadania plena, com todos seus direitos e deveres. 
3.2.2 Entrevista com Cláudio Jorge de Jesus, deficiente intelectual e ex-freqüentador do ateliê de Arte - Terapia do Centro Cultural São Paulo. (entrevista concedida pessoalmente, gravada, transcrita e aprovada)

1. Em sua trajetória de aquisição de autonomia você visitou museus? Em caso positivo, conte com que objetivo?

Visitei muitos museus. Minha cabeça estava amarrada em um círculo fechado, como se eu estivesse em um local escuro e preso, foi através daqui, deste centro cultural que minha mente começou a abrir, parece que entrou um clarão dentro de minha mente, parece que estava vivendo em um mundo muito escuro. Eu entrava em um museu e achava que iria acontecer como quando entro em uma crise onde começo a ter medo de tudo, tudo me faz ficar com medo, parece que meu coração vai acelerar tanto que vai sair pela boca, então eu fico com uma ansiedade e minha cabeça fica toda atrapalhada.

Com o decorrer do tempo, eu fui aprendendo que o museu está ali, parado, e comecei a freqüentar os museus e recomendaria às pessoas que não tem este costume. O museu não é aquilo que a gente pensa, antes eu pensava que o museu era uma coisa viva, que ia me atacar, me prender, me machucar, e o museu não é nada disso que eu pensava. Freqüentei muitos museus com a Professora Carmita aqui no Centro Cultural, fui para diversos lugares. É que tenho a dizer dos museus.

\section{Atualmente você visita museus por que razões e com que freqüência?}

Hoje eu visito museus porque foi através dele que comecei a enxergar muitas coisas boas da vida e freqüentava os museus também porque a Professora Carmita nos levava, então quando tinha a possibilidade de ir, eu ia, pois com o grupo não pagávamos e eu sou uma pessoa que não tenho condições de pagar. Eu dependo muito da minha mãe e não é sempre que dá. Antigamente eu tinha uma carteirinha de ônibus que eu não pagava condução para me locomover até os lugares, hoje é complicado, porque eu não trabalho. Eu não trabalho porque não posso ficar em locais fechados, abafados, minha mão começa a ficar em um estado que eu fico até sem 
unha, fico nervoso, começo a me morder todo, começo a me arrepiar e nada me segura naquele lugar. Eu dependia muito de condução de ônibus, minha mãe sempre me ajudou, mas hoje eu não tenho mais essa condição de estar indo para os lugares, então eu perco de estar indo aos museus e outros lugares.

Na semana passada a Professora Carmita falou que as atividades (Ateliê de Arte e Saúde Mental) iriam acabar e se eu poderia vir para a entrevista, ela se atrapalhou com a data e eu acabei vindo duas vezes, quase sem poder pagar. Quando eu tinha a carteirinha de ônibus eu podia ir além dos limites. Para mim é difícil visitar os museus nestas condições, pois haja dinheiro para tudo isto.

3. Você já foi consultado na realização de alguma proposta cultural/artística em benefício de pessoas com deficiência? Em caso afirmativo, exemplifique as propostas e resultados.

Nunca ninguém me parou, como você, para fazer uma pesquisa assim, mas o pessoal do CCSP fez uma pesquisa para saber como eu me saí visitando as exposições. Fizeram esta ficha em 2006, em dezembro, quando realizamos nossa festa de fim de ano no Parque do Ibirapuera, então a Professora Carmita questionou o que poderíamos sugerir para melhorar e para conhecer em 2007, eu falei que se o espaço (do ateliê) desse para todo mundo eu gostaria que viessem mais pessoas como eu. Foi difícil para mim, pois não existe só eu com deficiência mental, conheço muitas pessoas assim. Também sugeri visitar mais exposições, e que seria importante que o médico que nos acompanha pudesse vir e ver nosso trabalho. Eu tenho um médico que tudo que eu falo para ele, parece que ele não acredita, ele só me passa remédios, ele nunca faz uma pergunta para investigar como estou me sentindo, se estou bem. Eu sempre falo para ele que desde que bati minha cabeça, parece que tem bichos dentro dela que começam a me agoniar.

A Professora Carmita falou que tentaria correr atrás de tudo que sugerimos para 2007, no entanto neste ano tive uma notícia ruim, de que nossas aulas, por conta de espaço iriam acabar. O que escrevi naquele papel eram coisas boas, para visitarmos outras exposições, freqüentarmos outros lugares, fazer um campo novo de amigos e 
pessoas diferentes além de nosso grupo. Foi uma coisa que se distanciou por conta desta mudança, ficou tudo diferente para nós. Como se a Terra virasse de cabeça para baixo, ficou tudo distante, diferente.

4. Considerando políticas de acessibilidade para pessoas com deficiências em outras áreas (educação, saúde, transporte, etc.), como você analisa a condição dos museus em relação às pessoas com deficiência? Que exemplo você daria de uma prática adequada considerando os aspectos físicos, conceituais e políticos?

Eu aprendi uma coisa aqui no CCSP com a Professora Carmita, ela sempre falou para nós: "Se tiver um monitor para acompanhar vocês, vocês serão acompanhados por ele, mas se você aprendeu aqui uma vez com o monitor, amanhã se você traz sua família e não tem essa possibilidade, você vai ser o monitor". Todas as exposições que a Professora Carmita nos levou, as pessoas nos trataram muito bem, nos deram total atenção. Inclusive a gente tinha uma amiga do grupo que vinha com a mãe de idade e que visitava os museus conosco, ela não podia andar muito porque se cansava e sempre ofereciam cadeiras-de-rodas para ela andar a vontade.

O que eu tenho a dizer não são coisas ruins, são coisas boas, pois todas as vezes que fomos a um teatro, a um museu sempre tivemos monitor. Algumas vezes fomos no Sesi na Avenida Paulista e lá tínhamos uma monitoria tremenda que nos dava toda atenção. Eu não posso ficar muito tempo de pé pois me dá tontura e eu quase caí de um andar para o outro, neste caso me deram total atenção, tanto os monitores, quanto os psicólogos que nos acompanharam, então não tenho o que dizer. Todos os locais que fomos tínhamos um monitor que dava total atenção para nós e eu ficava muito feliz porque não íamos a um museu para pensar: quem vai nos dar atenção? Todo mundo nos deu atenção. Foi muito bom.

5. Como você acha que as pessoas com deficiências devem agir para incentivar a acessibilidade nos museus e outros equipamentos culturais e qual a importância de incluir este público nessa esfera sócio-cultural? 
Os museus são muito importantes para as pessoas com deficiência mental para que estas pessoas não vejam o mundo como um monte de tijolos, uma parede intransponível. O museu é uma coisa muito importante para pessoas como eu. Às vezes as pessoas me olham e dizem que eu não tenho nada, mas eu gostaria que pudessem me enxergar por dentro. As pessoas com deficiência mental conseguiriam vencer um obstáculo, como eu consegui ao visitar os museus. Eu falo vencer, pois hoje eu estou bem, estou conseguindo conversar com você, amanhã não sei nem o que aconteceu aqui, então começa a mudar tudo. Eu vivo 16 anos há base de remédios, graças a Deus com muita saúde e com a presença de minha mãe que está viva.

$\mathrm{Eu}$ acredito que se as pessoas com deficiência mental fossem a diante conseguiriam. Elas vêem o problema muito preso a elas, elas estão em um mundo como antes eu estava, preso. Aos poucos elas conseguem vencer, como eu que estou vencendo até hoje e quando alguém as convidar para vir a um lugar como este (CCSP), que as portam estejam sempre abertas, como estiveram para mim. Pois estas pessoas vão começar a conviver e aprender.

Tem muita gente, como outro dia ouvi do motorista de um ônibus, que acha que as pessoas com deficiência mental são rejeitadas, mas não somos rejeitados, somos seres humanos, simplesmente o que acontece é que sofremos um problema, mas que pode ser resolvido, demora, mas pode ser resolvido.

Eu hoje gostaria de ter muitos amigos iguais a mim, nós aqui conhecemos a Biblioteca Braille, eu gostaria que eles (deficientes visuais) pudessem nos enxergar, mas só pelo movimento de tocar acho que eles estão mais próximos de nós. Então penso que para as pessoas com deficiência mental seria a mesma coisa, poderíamos conviver mais próximos de todos. Eu acho que nunca podemos falar não a nada, acho que sempre devemos abrir as portas para todos, pois somos seres humanos.

Quem tem uma deficiência mental poderia subir um passo de uma escada e ver que ninguém ao redor está ali para dizer não, que não é bem vindo, mas sim para acolher, como aqui eu fui acolhido. Eu tentei nunca faltar aqui, mas as vezes por problema de saúde ou necessidade de ir ao médico ou à terapia eu tive de faltar, mas eu me dei muito bem e espero que o próximo se dê tão bem quanto eu. 
A Professora Carmita não foi só uma professora, foi muito mais do que uma amiga, aquela amiga que senta e conversa com você. A Professora Carmita, a Professora Ana e uma outra que não me lembro o nome, são pessoas que sentam com você, conversam, perguntam se você está bem. Se você estivesse lá pra baixo, como vi muitas amigas chorando, sem vontade, as professoras colocavam o lápis em suas mãos e diziam: "transforme esta realidade e se concentre no lápis que você vai perder esta tristeza". Eu falo muito da Professora Carmita, pois ela é uma pessoa que se preocupa conosco. Até quando não tínhamos sala para pintar ela sentava com a gente em qualquer canto do CCSP, mas ela nunca perdeu as esperanças de nos dar atenção, até hoje. Então eu sempre vou vir aqui, independente se tiver trabalhos para fazermos, eu sempre virei ver a Professora Carmita e pessoas que eu conheci aqui no CCSP.

Agora no último dia que ela marcou, que tínhamos que nos encontrar no Hospital Municipal para ela se despedir de nós eu queria compartilhar a sua tristeza porque ela estava muito triste, eu vi nos olhos dela que ela ia chorar. E ontem eu já vi que ela está com outro aspecto, sabendo enfrentar um fato da vida. É como perdermos um ente querido. A gente se emociona muito. Eu vim aqui ontem para participar da entrevista e foi como se eu estivesse vindo em uma terça-feira fazer meu trabalho, minhas pinturas e toda vez que eu passo ali naquela sala eu fico triste, pois lá era nossa sala. Antes era em cima, quando comecei. Muita coisa mudou, mas espero que a Professora Carmita esteja sempre conosco e espero que as portas se abram para outras pessoas que tem deficiência mental e outras deficiências, que não tenham as pernas, mas que tenha o corpo, que tenha o coração, isto é tão bonito ter o coração, e que aquela pessoa que não enxerga faça parte de nosso grupo também ou qualquer um, não temos preconceito de nada, todos serão bem vindos, como a Professora Carmita falou há uns quatorze anos, que todo mundo seja bem vindo e é assim até hoje. Nosso grupo já chegou a ter cinqüenta pessoas e hoje tem mais ou menos umas dez ou quinze pessoas. As pessoas achavam que pessoas como nós não iriam aprender nada aqui e que isto era uma maluquice, mas uma parte de nosso grupo foi guerreira, nós acreditamos e estamos até hoje. Nós continuamos porque gostamos. Eu gosto muito daqui, foi aqui que eu fui aprendendo a resolver meus problemas. Não 
conseguimos nos afastar, me dei bem, fiz amigos que estão comigo até hoje e me sinto muito feliz de estar neste grupo. 
3.2.3. Entrevista com Eduardo Palma, deficiente físico e arquiteto. (cedida por email)

1. Em sua trajetória de aquisição de autonomia você visitou museus? Em caso positivo, conte com que objetivo?

R. Sim, com o objetivo de obter novos conhecimentos.

2. Atualmente você visita museus por que razões e com que freqüência?

R. Visito pelo motivo citado acima e freqüência $2 x / a n o$

3. Você já foi consultado na realização de alguma proposta cultural/artística em benefício de pessoas com deficiência? Em caso afirmativo, exemplifique as propostas e resultados.

R. Não

4. Considerando políticas de acessibilidade para pessoas com deficiências em outras áreas (educação, saúde, transporte, etc.), como você analisa a condição dos museus em relação às pessoas com deficiência? Que exemplo você daria de uma prática adequada considerando os aspectos físicos, conceituais e políticos?

R. Dos locais que é de meu conhecimento, não problema em relação a acesso, exceto estacionamento, então classifico como boa, comparando com outros locais.

5. Como você acha que as pessoas com deficiências devem agir para incentivar a acessibilidade nos museus e outros equipamentos culturais e qual a importância de incluir este público nessa esfera sócio-cultural?

R. Devem agir tendo uma maior freqüência nestes lugares de pessoas portadoras de deficiência físicas e a importância é de poder mostrar a população, no sentido de conhecimento, de que existe uma grande gama de pessoas nestas condições e que podem fazer tudo o que pessoas sem algum tipo de deficiência faz, apenas com limitações e por isso a necessidade de locais adaptados. 
3.2.4. Entrevista com Evgen Bavcar, deficiente visual, fotógrafo e Professor de Filosofia da Sorbonne. (concedida por telefone, gravada, transcrita, traduzida e aprovada)

Eu conheço este problema em todo o mundo e penso que neste momento se faz isso de uma maneira "guetizada" (com muitas segregações). Os museus dizem que criam espaços para os cegos como a Sala Tátil do Louvre, por exemplo. Acho que esta política de criar salas para cegos não é boa e não esta certa, pois acaba criando "guetos". Não concordo com esta política, pois acredito que é possível trabalhar com "outras percepções" nos museus. "Olhar com as mãos" e "com o corpo" é um questão para todas as pessoas e não apenas para cegos, e eu prefiro chamar esta idéia de "museu de outras percepções".

No Museu do Louvre, a sala tátil é como uma forma de esmola, um pequeno espaço de $82 \mathrm{~m} 2$. No Museu D’Orsay, o espaço tátil é muito pequeno também. São somente umas formas de caridade para com os cegos. E é contra isso que protesto, pois acho que é humilhante. Penso que com um pouco mais de trabalho, imaginação e respeito pode-se fazer muito melhor, e fazer espaços de outras percepções para todos, não apenas para cegos. Existem muitas pessoas de idade, e que também não enxergam bem, por exemplo, para estas pessoas é interessante olhar uma obra de arte de diferentes pontos de vistas e de todas suas perspectivas. Obras como a Vênus de Milos poderiam ser mostradas de diferentes maneiras, com diferentes percepções, de cima, de baixo, da direita, da esquerda, e isso não é só para cegos. Meu desejo é a de criar a possibilidade dos "museus de outras percepções", e este programa é compartilhado por meus amigos de Porto Alegre e do México. Minha idéia é fazer que também os cegos possam despertar nos outros uma maneira diferente e nova de olhar as obras de arte.

1. Em sua trajetória de aquisição de autonomia você visitou museus? Em caso positivo, conte com que objetivo?

Muitas vezes as pessoas querem me acompanhar nos museus pois, assim são obrigadas a olhar de outra maneira. Eu acredito nas perguntas como: "O que você vê?", "O que está diante de você?", "O que representa este quadro?", "Qual é a cor?". As 
pessoas que descrevem uma obra devem criar uma representação interior desta obra, o quem nem sempre acontece, pois no mundo moderno as pessoas geralmente visitam museus sem poder olhar, sem poder criar uma representação interior, é um olhar superficial, não é um olhar espiritual, interior. Muitas vezes estudantes pedem para me acompanhar em museus para olhar de uma maneira diferente.

Eu visito exposições e gosto quando permitem que eu "olhe de perto", não digo tocar, porque dizer tocar é uma expressão das pessoas que vêem com olhos. "Olhar de perto", significa simplesmente que meu olhar é bem de perto, e repito: não é um tocar, tocar é a lógica das pessoas que vêem a minha lógica é apenas pode olhar de perto. Olhar corpo-a-corpo. A abordagem corpo-a-corpo com uma estátua, por exemplo, me deixa muito feliz, significa olhar não só com minhas mãos, mas com minha presença corporal, e um cego não olha somente com os olhos, mas também com todo o corpo, esta é a diferença.

Nós vivemos em um mundo oculocentrista, onde os olhos são o centro do mundo e da verdade, as pessoas observam a arte e a arquitetura somente com os olhos. A arquitetura moderna é uma arquitetura para os olhos e não para o corpo. A famosa pirâmide do Louvre é uma arquitetura para os olhos e não para o corpo, porque o corpo não se sente bem nesta pirâmide de vidro. Há muitas outras coisas na arquitetura que são somente expressão dos olhos e não do corpo, eu prefiro sentir a arte "com o corpo" não somente com os olhos - "com o corpo", como diz Spinoza, "corpo, espírito e consciência do corpo", ou seja, se eu sinto arte com o corpo sinto arte com o espírito.

\section{Atualmente você visita museus por que razões e com que freqüência?}

Eu visito museus e galerias e muitos artistas me pedem para escrever sobre suas obras. Eu gosto muito de visitar o Museu do Prado, e com freqüência o faço na companhia de uma amiga. Uma vez, esta amiga me disse: "Eu vejo Maja Desnuda", e eu pergunto: "o que você vê? Repita!", e ela repetiu: "Eu vejo Maja Desnuda", então, eu digo a ela que Maja não está nua. Certas pessoas começaram a se aproximar para 
tentar escutar o porquê de minha afirmação. Eu repeti que ela não está nua. E depois comecei a explicar que ela não estava nua, pois estava velada pelo olhar de Goya, por isto não estava nua. Era a minha interpretação. Posso dizer que esta moça foi comigo pela primeira vez ao Prado e viu as coisas que não poderia ver sozinha, porque simplesmente lhe formulei as perguntas "diferentes": "Como é a luz neste quadro?", "Como é a cor?", etc., e tudo isso, pedindo a ela de haver precisão, muita precisão! E o resultado foi interessante, para ambos. Não tenho duvidas de que a descrição é uma forma de interiorizar os quadros, as pinturas. Por exemplo, para compreender o famoso quadro "As Meninas", de Velásquez, um amigo me descreveu-o por telefone, por uma semana, duas horas ao dia, foram mais de dez horas para descrever este quadro, colocá-lo em palavras, e isso precisa de muito mais tempo do que apenas olhá-lo.

Eu penso que todas as coisas podem ser apresentadas aos cegos, mas com a colaboração dos cegos. Escutar a experiência e opinião dos cegos é necessário e urgente. O problema é que as pessoas que vêem apresentam aos cegos as coisas com a lógica das pessoas que vêem. É preciso entender a lógica dos que não vêem, uma lógica mais profunda, uma lógica que chamo de "lógica grega", de um olhar interior, de um olhar espiritual, um olhar com apresentação interior.

3. Você já foi consultado na realização de alguma proposta cultural/artística em benefício de pessoas com deficiência? Em caso afirmativo, exemplifique as propostas e resultados.

Atualmente, estou colaborando com o VSA (Very Special Arts), no Brasil. Hoje, me interessa trabalhar com museus e instituições culturais que se interessam em criar espaços "de outras percepções", onde eu tenha autonomia para fazer da minha maneira, que é a maneira mais próxima da experiência dos cegos e das pessoas com deficiência. Eu queria, e sei que posso, dar bons conselhos e contribuir com essas iniciativas, pois tenho boas idéias para "museus de outras percepções". Por exemplo, idéias como um barco "de outras percepções" ou árvores, etc. Também penso a apresentação de uma cidade em miniatura, como os mimundos na Áustria e na França, 
eu queria criar para as crianças cegas uma Mini São Paulo: pequenas casas que podem ser tocadas em um espaço de vinte ou cinqüenta metros, na qual as crianças possam entrar.

Se existe vontade, pode-se fazer isto e mais. A partir de uma pintura se pode fazer um espaço tridimensional, onde os cegos possam entrar. Uma pintura clássica da Renascença, por exemplo, poderia transformada em um espaço tridimensional onde bastaria entrar e tocar para saber onde esta cada coisa. Como um teatro imóvel. Os cegos têm muitas idéias, basta que sejam escutados.

4. Considerando políticas de acessibilidade para pessoas com deficiências em outras áreas (educação, saúde, transporte, etc.), como você analisa a condição dos museus em relação às pessoas com deficiência? Que exemplo você daria de uma prática adequada considerando os aspectos físicos, conceituais e políticos?

Em todos os museus o acesso das pessoas com deficiência ainda é marginal. Por exemplo, em todos eles as cópias são preparadas, mas ninguém tem acesso. Eu não me interesso pelos originais, o importante é a forma, e devo dizer que no Louvre existem mais cópias disponíveis para vender que as cópias disponíveis para olhar, ou seja, não podem ser "tocadas" pelos cegos. No Museu D’Orsay as copias também são muito poucas, uma verdadeira esmola. Hoje, as poucas iniciativas que existem são apenas ações muito tímidas. É preciso criar em todos os museus espaços para ver, "espaços de outras percepções". Um espaço para ver com as cópias, onde se pode criar caminhos diferentes, onde se pode olhar de todos os ângulos. Neste momento, tudo ainda acontece em pequenos guetos, e serve apenas para que os diretores dos museus mostrem que tem "consciência" de que é preciso pensar nas pessoas com deficiências. é inegável que existem muitas coisas que se poderia mostrar aos cegos, mas infelizmente, ainda não somos, suficientemente, levados em consideração. Assim como também não se considera o que os cegos podem mostrar as coisas às pessoas videntes. Por isso insisto em que é preciso desmistificar a cegueira, e assumir que os cegos também têm idéias. Existe uma frase de Dostoevskij: " $\quad$ A beleza vai salvar o 
mundo", frase esta empregada por muitos museus como se houvesse um pensamento "novo" de que a beleza pode salvar o mundo. E pode! Mas uma beleza democrática, para todo mundo não somente para uma parte das pessoas.

Essa semana, devo visitar o Museu do Erotismo, em Paris, e conto isso pois penso que é uma boa idéia mostrar o Museu do Erotismo para os cegos, pois Eros, o deus do amor, na cultura Grega, é um deus cego que vive na Penúria, o que da a dimensão erótica desta condição. Quando contatei o museu dizendo que era cego, a pessoa responsável me explicou que o museu contava com três responsáveis pelas visitas guiadas, uma especialista em estética, outra em etnologia e outra em artes plásticas, mas eu disse a ela que não precisava ser acompanhado e que poderia olhar sozinho, mas esse é uma boa possibilidade para alguém que não conhece. Neste museu é possível olhar, e tocar tudo, e eis a grande diferença.

Em uma certa ocasião em São Paulo, conversei com uma senhora muito simpática que realizava retratos para cegos - agora não me recordo o seu nome. Eu disse a ela que ela estava cometendo um erro, pois utilizava em demasia a lógica dos videntes e ao fazer retratos para cegos. Ela precisaria, antes, entrar em um mundo de outra percepção. Ela era muito inteligente e compreendeu súbito a minha idéia.

Fazer representações é um processo que pode ser feito em etapas, e de maneiras muito diferentes, táteis e tridimensionais, e com riqueza de detalhes. é possível apresentar em três dimensões um retrato ou mesmo quadros de Rembrandt, como "O Sacrifício de Isaac", por exemplo, tanto cegos como para as pessoas que vêem. Isto seria uma experiência nova. Gostaria de fazer isso, mas se não posso fazer com nenhum museu do mundo, gostaria somente de escrever essa minha idéia sobre como eu "vejo" e como as apresentaria de formas diferentes. E é preciso experimentar alguns "deslocamentos", senão veremos tudo e todos do mesmo ponto de vista. é o que eu digo sobre as esculturas nos museus, que são sempre apresentadas de maneira frontal, sempre de frente para os olhos, não para o copo, não para o espírito. é assim é em todos os museus do mundo, o mesmo clichê de representação da estátua. Terrível! 
E mesmo uma igreja, pode ser representada com seus detalhes. Na Espanha, por exemplo, existe um museu para os cegos, um pouco estranho, pois fazem miniaturas de igrejas mas não são capazes de representar uma janela no tamanho natural, para dizer qual é a dimensão real da igreja mostrada na miniatura. Quando se apresenta um elefante a uma criança cega, precisa mostrar um elefante pequeno, pois o cego precisa entender a forma com suas mãos e corpo e mostrar um pé no tamanho natural para dizer: este é o tamanho natural de um elefante. São "detalhes" fundamentais que se negligencia. É importante que essa apresentação do mundo seja de uma maneira lógica e espiritual e não somente de uma maneira exótica. De uma igreja, por exemplo, pode-se mostrar somente um detalhe, como a Santa Maria de Fiori, onde eu vi uma maquete original, fantástica, uma maquete da época da construção, mas eu apresentaria a mesma coisa aos cegos acrescentando com um detalhe da igreja real. Outro exemplo: a Igreja de São Pedro pode-se mostrar a miniatura de toda a igreja e depois uma parte maior, com a cúpula de Michelangelo. Ou ainda, em Florença, podese mostrar tudo, mas precisa contar com a colaboração de um cego que conhece.

Eu tenho a impressão que as pessoas tem um pouco de medo de mim porque digo as coisas da minha maneira, não entro neste jogo de exótico, de exotismo. Estudei arte por toda minha vida e percebo que as pessoas têm um certo medo, digamos. Recentemente, fui convidado para colaborar em um projeto menos de um museu na Costa Rica, ao falar com os responsáveis senti que eles ficaram com medo. Eles me contaram o que "mostram para os cegos" e eu argumentei que na verdade não mostram nada, e que repete a ação e caridade que é humilhante para os cegos. Este projeto, mais uma vez não era uma coisa acessível, pois uma coisa acessível deve ser bem pensada e planejada com pensamento e espírito.

5. Como você acha que as pessoas com deficiências devem agir para incentivar a acessibilidade nos museus e outros equipamentos culturais e qual a importância de incluir este público nessa esfera sócio-cultural? 
Quando visitei o Museu Reina Sofia, em Madrid, e não queria pagar nem para mim, nem para meu acompanhante. Eles me perguntaram o porquê, e eu disse que não tinha nada para os cegos ali e perguntei: "o que podemos ver?", e eles não tiveram resposta. É preciso que as pessoas se sensibilizem. Os museus são excludentes e as pessoas com deficiência devem exigir seu direito de participação, pois a arte é para todo mundo não só para as pessoas "normais". Todos os museus são criados para pessoas "normais", para a média normal. A dita "nova museologia", a museologia do novo milênio, precisa abrir os museus para as pessoas com deficiências, se estas pessoas entram na vida, então, também devem entrar em instituições artísticas, museais e de educação. Precisamos falar dessas coisas de uma maneira nova e muito crítica. Precisamos dizer que o Louvre e grandes museus, como o museu do Vaticano, são excludentes e que não fazem conta das milhões de pessoas que são deficientes de uma maneira ou de outra. Não se trata somente de viabilizar visitas do ponto de vista de melhores e mais condições para poder "olhar", mas também para poder andar: é preciso que haja cadeiras-de-rodas, elevadores, etc, por exemplo. Uma pessoa que anda em uma cadeira-de-rodas não pode ver uma estátua da mesma perspectiva que uma pessoa que anda em pé, também uma criança não terá a mesma perspectiva. Os museus não pensam nas crianças que são pequenas e tem que olhar de baixo. É uma tragédia pensar em termos da normalidade. Eles pensam nos especialistas, que são adultos e olham sempre da mesma perspectiva. Não as perspectivas das crianças e dos cadeirantes, das pessoas que não enxergam bem, e isso é triste e é um problema. Os museus têm uma norma média, que é uma norma de exclusão e racismo, da percepção, de racismo estético e corporal. Estes museus são patrimônio da humanidade, e são nossos! E quando uma pessoa não pode olhar de todas as perspectivas possíveis uma obra de arte significa que não pode ver esta obra de arte.

A famosa Monalisa, só pode ser vista de uma perspectiva estando em qualquer parte da sala, e só se pode ver de um lugar e por um curo período de tempo, pois há muita gente nesta sala. Eu prefiro olhar a Monalisa estando na minha casa, com uma reprodução e com a descrição de alguém que pode olhar muito de perto - olhar os 
detalhes e mudar todas perspectivas, e assim posso conhecer melhor o problema da forma e da estética da obra. Isso para mim é muito mais interessante do que o Louvre com seu originalismo, e isso é válido para todas as obras de arte. Se não se pode ver de uma forma pessoal e individual, um museu é um museu, por clichê, "supermercado". Por que só os especialistas podem ver de muito de perto e fazer fotos muito precisas para estudar? Eu queria olhar da mesma forma do especialista com todos os recursos, não porque sou cego, mas porque me interessa. Em Viena, me permitiram fotografar um Bruegel, bem de perto, para um amigo que escreveu um livro. Tenho essas fotos com muitos detalhes e prefiro que alguém me descreva estas fotos, pois é mais preciso do que ouvir uma descrição em meio a muita gente, onde não se possa dispor do tempo necessário para a descrição. A descrição precisa de muito tempo. No Prado, comprei fotos das pinturas de El Greco e de Goya para poder olhar com precisão, e desta maneira continuo as visitas, na companhia de alguém que me a descreve. Outro exemplo, de algo que eu gostaria de fazer, é a criação de "contextos" para um museu moderno, para o "museu de outras percepções", em São Paulo. Eu chamaria especialistas para descrever as obras, para ter/ver a mesma obra a partir de diferentes olhares. Eu gravaria cada depoimento e proporia aos visitantes de ouvir tais descrições - "isto diz este senhor, isto diz este especialista desta obra, isto falou uma criança", etc, e com muitas destas descrições se poderia criar um museu fantástico. Acredito que com as descrições de uma obra de arte é possível fazer uma coleção de descrições muito diferentes; e, depois, com estas descrições cada pessoa poderá formar o seu olhar pessoal, e fazer muitas comparações. Por exemplo: se uma pessoa me diz que

De LaTour tem um vermelho-cerâmica, e outra pessoa diz que é um vermelho diferente, eu prefiro criar um vermelho pessoal em minha cabeça.

Os museus estão preguiçosos e estão presos em normativas e clichês. Os museus modernos não são críticos e não tem feito grandes progressos. Mesmo museus que vendem uma imagem progressista, em verdade conservam sempre a mesma maneira de olhar, e mais uma vez utilizo o Louvre como exemplo de uma instituição preservacionista. Para mim interessam as novas perspectivas, outra percepção, isto permite criar uma arte nova de outras perspectivas. Nós não podemos olhar com olhar 
do século XVIII e XIX, devemos olhar com as possibilidades de nosso olhar moderno, com todos os recursos tecnológicos, espelhos, lentes e aparatos ópticos e perspectivas. Eu tenho um projeto fantástico de fazer uma Monalisa para os Cegos, seria uma representação moderna para as pessoas que não olham com os olhos, mas com o olhar interior, um olhar novo sobre a Monalisa. Estudei muito, muitas horas de descrição sobre essa obra, e posso dizer que conheço tudo, todas as sombras sobre o rosto, como é o nariz, como são os pelos, os olhos, a direção dos olhos e a partir desses dados eu poderia fazer uma coisa fantástica: uma criação tridimensional, por exemplo. é uma pena que as pessoas de contem apenas com a Monalisa apresentada de uma maneira demasiada visual. Outra coisa fantástica que eu gostaria de fazer seria representar o incrível quadro de Rembrandt, "Ronda Noturna". Um espaço com as figuras em três dimensões, com os soldados, etc. Eu gostaria tanto de mostrar a minha representação desse quadro, pois tenho uma idéia muito precisa sobre a luz a ser inserida - estaria de manhã, muito cedo, um detalhe que é possível graças aos avanços no campo das técnicas de iluminação. Todavia, são tantas as pinturas fantásticas que existem, que é impossível não imaginá-las representadas de outras maneiras. Sem esquecer os retratos impecáveis de El Greco, com todos seus detalhes. Seria mesmo interessante "exagerar" determinadas partes para destacar alguns detalhes, fazendo diferentes copias do mesmo retrato com destaque de um elemento ou de outro em cada uma. Enfim, tenho investido muito para viabilizar essas "minhas idéias", pois tento chamar atenção para ao menos dois importantes detalhes: é preciso mais imaginação e menos caridade para com os deficientes. Podemos dizer sem medo: "Sim, existe a "deficiência museal", a "deficiência de imaginação nos museus!", e essas instituições são mais deficientes do que as pessoas que não enxergam, por exemplo. 
3.2.5. Entrevista com Leandra Migoto Certeza, deficiente física e jornalista. (cedida por email)

1. Em sua trajetória de aquisição de autonomia você visitou museus? Em caso positivo, conte com que objetivo?

Sim, eu visito museus desde criança. Sempre amei a vida cultural. Tive o privilégio de ter uma família de artistas e intelectuais que me ensinaram a amar a arte. Desde bem pequena via 'fotos' nos livros da minha tia, que é museóloga e artista plástica, e ficava super curiosa para conhecer os artistas. Depois comecei a ler os livros e me interessar ainda mais por arte. Fui a uma Bienal de Arte por volta dos 11 anos de idade e vibrei muito!

Depois comecei a estudar história do Egito na escola a me apaixonei por museus de história. Visitei o museu do Ipiranga e muitos outros. Conforme fui avançando nos estudos continuei minha vida cultural com toda força. Sempre dependi de carona, táxi ou transporte da Prefeitura para viabilizar a ida, e a volta aos museus. Conforme adquiri um pouco de autonomia financeira, consegui ir aos museus com mais independência.

2. Atualmente você visita museus por que razões e com que freqüência?

Visito todos os anos o máximo de exposições de arte e museus que tenho condições. Aproximadamente três museus e cinco exposições por ano, dependendo da minha situação financeira para arcar com as despesas de transporte. AMO arte e história da arte, por isso valorizo muito o setor.

Fui monitora educacional e artística em duas exposições temporárias maravilhosas: "Êxodos" - fotografias de Sebastião Salgado, e "Palco em Cena" - a história do teatro montada pelo cenógrafo Serrone. A primeira no SESC Pompéia e a segunda no SESC Vila Mariana, ambas em 2000. Em 2006, tive o privilégio de ser educadora na Bienal de 
Arte de São Paulo. Todas essas experiências foram extremamente significativas, em minha vida pessoal e profissional. Sinto-me muito realizada trabalhando com arteeducação. Sempre abordo e pratico a inclusão de forma ampla, tanto pela minha condição física como pela minha forte militância social.

3. Você já foi consultado na realização de alguma proposta cultural/artística em benefício de pessoas com deficiência? Em caso afirmativo, exemplifique as propostas e resultados.

Quando fui selecionada para ser monitora educacional na exposição "Êxodos", no SESC Pompéia, assisti a uma palestra sobre inclusão feita pela ong SORRI Brasil. Achei muito importante o tema fazer parte do nosso curso de formação. Porém, as controvérsias foram enormes, pois terminado o curso, fui direcionada de forma imperativa a assumir um posto de trabalho administrativo, e não conduzir monitorias com as escolas. Falaram que eu não conseguiria realizar o trabalho com competência devido a minha dificuldade de locomoção (e olha que eu estava de cadeira de rodas em um local totalmente acessível, imagina se o local tivesse escadas...).

Então, como sou guerreira e insisto muito para propagar a verdadeira inclusão na prática, simplesmente, desobedeci completamente à ordem e fiz ótimas monitorias, (modéstia parte), além de recepcionar as escolas logo na entrada da exposição, fazendo a introdução da visita, e conduzindo os alunos com muita competência por todo o espaço expositivo. É óbvio que, infelizmente, enfrentei muitas dificuldades físicas e comportamentais.

A coordenadora dos monitores olhava torto para mim todos os dias! Era incrível como mesmo com os meus colegas de trabalho contando a ela que minhas monitorias estavam atendendo às expectativas, ela ainda queria que eu ficasse atrás de um balcão atendendo telefone. Mas com o passar do tempo, os professores e até alguns alunos comentavam, ao fazerem as avaliações do trabalho, que o meu desempenho era ótimo. E durante as monitorias eu também era elogiada. Os alunos mais bagunceiros ficavam admirados quando me viam logo na entrada. E depois do susto em ver uma pessoa em uma cadeira de rodas 'dando aula', para eles, me respeitavam e ficavam quietinhos. É 
claro que tinham aqueles que faziam piadas, mas o que eu não tolerava era o preconceito deslavado e 'escondido' de algumas professoras mal educadas que torciam o nariz para eu meu trabalho, e até dispensavam a monitoria. Mas quando elas viam outra escola aproveitando muito a visita, ficavam espantadas! Aí já era tarde demais!

Trabalhar nessas exposições foi um divisor de águas na minha vida profissional e pessoal. Amei cada minuto. Fiz oficinas de literatura sobre êxodos, com o material educativo e o mural no SESC Pompéia. As fotos do Sebastião Salgado mostraram uma realidade que muitas pessoas nem sonhavam que existiam. Creio que a minha monitoria além de trabalhar conceitos fundamentais sobre a importância da solidariedade, da ética, da total falta de compromisso dos governantes do mundo, da ganância de poder, da dor, e do sofrimento dos seres humanos sem pátria, mostrou que é possível viver com uma deficiência e ser feliz!

No SESC Vila Mariana, o lúdico do teatro deu lugar à fantasia. Minha participação foi importante para plantar nas crianças a semente da convivência com a diversidade inata a todos nós. Vivi momentos lindos, pois também fiz ótimas monitorias para crianças com deficiência, e quebrei o gelo dos meus colegas monitores em trabalhar com elas. Foi inesquecível e maravilhoso. Os detalhes dessas experiências são muitos. Eu te conto em outra oportunidade, pois tenho pouco tempo para terminar esse questionário. Já na Bienal de Arte eu pensei que seria mais fácil ser arte-educadora. Mas também enfrentei preconceito 6 anos depois das duas primeiras exposições. Infelizmente, a inclusão demora muito pra entrar na cabeça das pessoas. Logo que fui selecionada para o curso, tive muitas dificuldades de transporte, mas nenhum patrocinador da mega exposição se dispôs a me dar um apoio, já que cidade é totalmente inacessível. Enfrentei uma barra para fazer o curso preparatório de dois meses, graças ao apoio da minha família, e tirei dinheiro das economias para pagar o táxi, pois estava desempregada.

Quando começamos o trabalho, minha surpresa foi maior. A coordenadora dos monitores também me colocou em uma função completamente administrativa. Fiquei 3 semanas recepcionando as escolas na porta da Bienal, apenas conferindo papeis e 
passando o grupo para os monitores. Ora bolas, não fiz 2 meses de curso e estudei muito só para falar: bom dia, sejam bem vindos! Fiquei louca da vida e rodei a baiana!! Gritei muito para conseguir fazer a primeira monitoria sozinha e com muita competência, modéstia parte! No começo fiz duas monitorias, mas com um supervisor me atrapalhando. Só eu tinha que ter um acompanhante durante o trabalho. Puro preconceito.

Meus colegas de trabalho tentaram explicar aos coordenadores que eu tinha total condição de rodar a Bienal inteira com um grupo de 20 alunos e ser uma ótima monitora, mas eles simplesmente não ouviram e eu fiquei pagando para trabalhar totalmente frustrada e com muita raiva!

Só depois de ameaçar a abandonar tudo e explicar detalhadamente para eles que eu tinha totais condições de dar conta sozinha do trabalho, bastava só uma ajuda dos seguranças para subir e descer as rampas, finalmente, eles deixaram eu trabalhar em paz. Todas as monitorias foram fantásticas e eu agüentei firme! Fiquei super cansada fisicamente, mas minha mente e meu espírito estavam nas alturas. Foi uma experiência enriquecedora, afinal o tema da bienal era "Como viver junto". Que contradição, né? Bom, no final, fui elogiada pelo coordenador que mais teve receio do meu trabalho, e aplaudida pelos colegas de turma que sempre acreditaram em mim. Acho que o problema é o pessoal mais velho. Felizmente, a garotada já começa a despertar para a inclusão!

Sobre essas experiências quero deixar bem claro que sempre sou selecionada para um trabalho como arte-educadora somente pelas minhas qualificações. Nada de assistencialismo. Depois, quando digo que rodo a baiana é pura expressão, pois sempre tenho a maior paciência para explicar em detalhes o que posso e o que não posso fazer tendo uma deficiência física. Mas infelizmente, a grande maioria das pessoas já pré-supõem que eu não tenho competência. Aí só me resta mostrar cara a cara o que POSSO fazer!

Sempre tenho que ser determinada e firme na hora de argumentar e sempre preciso provar desafiando as pessoas que desconfiam de mim. Sinceramente, compreendo perfeitamente que a inclusão é um processo lento e muito complexo, pois mexe com 
estereótipos, tabus e pré-conceitos arraigados em uma sociedade paternalista, eurocêntrica, machista, conservadora, católica, sensacionalista, demagógica, e extremamente assistencialista, mas juro que é muito cansativo ter que sempre provar minhas qualidades.

É necessário que a classe artística e cultural abrace uma campanha pela inclusão. É preciso de informações corretas sobre deficiência, desenho universal, diversidade, direitos humanos, cidadania, diferenças, doenças, reabilitação, acessibilidade física e comunicacional, seguem a todos que lidam com a arte, em especial às pessoas mais experientes, como diretores de museus, curadores de arte, professores, educadores, donos de galerias, entre outros. São eles que sempre dão a martelada final, na hora de decidir se uma exposição será ou não acessível a todas as pessoas!

Os estudantes estão cada vez mais preocupados com a inclusão, mas eles infelizmente, não têm voz ativa na tomada de decisões, e penam bastante para tentar convencer os 'donos da arte'. O papel dos estudantes é continuar pressionando eles, mas de uma forma mais forte!

4. Considerando políticas de acessibilidade para pessoas com deficiências em outras áreas (educação, saúde, transporte, etc.), como você analisa a condição dos museus em relação às pessoas com deficiência? Que exemplo você daria de uma prática adequada considerando os aspectos físicos, conceituais e políticos?

Como você sabe $99 \%$ do planeta terra ainda não é acessível às pessoas com deficiência, e no Brasil, infelizmente, são raríssimas as exposições de arte e outras atividades culturais que respeitam a diversidade das pessoas sejam elas deficientes, obesas, gestantes, crianças, idosos, doentes, homossexuais etc.

Fisicamente os museus históricos, principalmente, ainda são terríveis. São têm escadas e mais escadas. Existem locais onde é mais fácil rodar com uma cadeira de rodas, mas os cegos não podem ter acesso a nada, e os surdos menos ainda. O que me deixa mais louca de vida é ver museus com adaptações completamente ineficazes. O MASP, 
por exemplo, tem 'rampas' que são formadas por escadas. O elevador está sempre com problemas. Espero que tenham melhorado, pois fui lá há mais de 5 anos.

A Pinacoteca de São Paulo é um exemplo de inclusão em todos os sentidos. O projeto de inclusão que a Amanda Tojal desenvolve é maravilhoso, além disso, o local é bem acessível para deficientes físicos. A reforma não atrapalhou o patrimônio histórico do prédio e ficou acessível a todos! Eles merecem nosso grande reconhecimento.

O prédio da Oca e da Bienal no Ibirapuera são bons, mas precisam de uns ajustes fundamentais. As vagas para estacionamento sempre são desrespeitadas e precisam ser fiscalizadas. Os elevadores e banheiros sempre estão trancados, e precisamos chamar os faxineiros para abrir a porta. Quando eu trabalhei na Bienal de Arte em 2006, o elevador, não sei por quê, não ia até o segundo piso. Era muito complicado empurrar cadeira de rodas pesadas naquelas rampas íngremes e extensas.

Além do mais, simplesmente, não há nenhuma sinalização visível para indicar a presença deles. Confesso que a direção da Bienal não gosta que os deficientes usem o elevador, porque ele serve aos funcionários! É realmente, o fim da picada. Eu que era funcionária temporária tinha que implorar para usar. Depois de tanto insistir, ninguém mais virava a cara pra mim. Mas no começo...

O MAM é outro exemplo de 'quase' desenho universal. Tem uma boa 'trilha' com piso podo-tátil para cegos (me corrija, se estiver errada), até a entrada. Mas a porta deve sempre ser aberta pelo segurança que nem sempre está lá. Dentro do museu, tem um elevador e o piso é acessível para cadeirantes. Porém, as exposições estão sempre em uma altura totalmente fora da linha de visão de quem usa cadeira de rodas.

Lá existe um telefone para surdos, isso é muito bom. Mas não há material impresso em Braille ou CD para cegos lerem os catálogos. O mais complicado é usar o banheiro 'adaptado meia boca'. Ele fica lá no FUNDO (na área de serviço) do museu, e não há nenhuma sinalização. É preciso pedir ajuda para os funcionários porque também está sempre trancado.

A grande maioria das unidades do SESC SP são acessíveis para pessoas com deficiência física, mas ainda deixa a desejar para cegos e surdos. Os espaços onde são 
realizadas as exposições são os melhores em SP em relação à acessibilidade, pois infelizmente, os museus ainda estão começando a despertar para a inclusão.

Bom, é claro que não poderia deixa de mencionar o Museu da FDN que é fantástico! Parabéns!

5. Como você acha que as pessoas com deficiências devem agir para incentivar a acessibilidade nos museus e outros equipamentos culturais e qual a importância de incluir este público nessa esfera sócio-cultural?

Confesso que é bem difícil para as pessoas com deficiência lutarem por espaços culturais mais acessíveis, pois $90 \%$ delas não têm condições financeiras, e principalmente, física (transporte e acessibilidade na locomoção) para visitar os museus. Mas estou percebendo que, felizmente, a situação está melhorando, e alguns museus estão se preocupando com a inclusão.

Cabe às pessoas com deficiência engajadas em políticas públicas lutarem para o tema ser debatido nas pautas das reuniões dos órgãos públicos. Mas é bem complicado falar da implantação de leis no Brasil, porque simplesmente não existem órgãos fiscalizadores em nenhuma área, ainda mais na cultural, que infelizmente, é sempre deixada em quarto ou quinto plano.

Mas cabe a todas as pessoas com deficiência conscientizarem a sociedade, solicitando às administrações dos museus, mudanças em suas políticas internas, para a inclusão ser colocada em prática. Só ficando de olho e cobrando conseguimos sermos vistos como cidadãos que pagam seus impostos e exigem respeito!

Ações práticas como escrever e-mails e cartas aos diretores de museus para solicitar acessibilidade, chamar o guincho quando um carro para na vaga destinada aos carros com adaptação, escrever comentários nas caixinhas de opinião que existem em alguns museus, mandar pautas para os jornais sobre acessibilidade em museus, e participar de projetos como o da FDN, são algumas sugestões para lutar pela inclusão.

Incluir as pessoas com deficiência na esfera cultural é mais do que uma obrigação de todos, pois elas vivem na sociedade, pagam seus impostos, e cumprem com seus 
deveres. Elas têm total direito de usufruírem da cultura de seu país. Conviver com a diversidade é enriquecedor!

3.2.6. Entrevista com Sabrina Denise Ribeiro, deficiente auditiva e professora de artes. (entrevista concedida por e-mail)

1. Em sua trajetória de aquisição de autonomia você visitou museus? Em caso positivo, conte com que objetivo?

Sim, já visitei MASP, MAC, MAM, Pinacoteca, MIS, Museu da Língua Portuguesa, Museu de Numismática do Itaú, Museu Paulista, Casa das Rosas, FIESP, Museu de Arte Brasileira da FAAP, CCBB, Conjunto Cultural da Caixa e outros museus. É muito bom fazer visitas porque é importante para aumentar minha bagagem cultural, principalmente porque sou formada nesta área de artes. A obras de artes dos museus explicam muito sobre a cultura, informação e expressão de uma sociedade no tempo e no espaço. Também pode pegar os folders para ler os textos informados. Sempre visitei estes locais pelo simples prazer de admirar uma boa obra-de-arte, e também porque é minha profissão e preciso estar sempre me atualizando.

\section{Atualmente você visita museus por que razões e com que freqüência?}

Sim, gosto de visitar os museus, porque a cada nova exposição tem sempre um elemento inovador. E pelo fato de eu ser artes plásticas, tenho muito interesse por assuntos relacionados às artes. Sempre que posso visito um museu: se tem uma nova exposição ou porque quero ver obras já conhecidas e belas. Vou aos museus pelo menos a cada 15 dias.

3. Você já foi consultado na realização de alguma proposta cultural/artística em benefício de pessoas com deficiência? Em caso afirmativo, exemplifique as propostas e resultados. 
Comecei trabalhando como monitora voluntária para surdos na Pinacoteca do Estado em 2004. Primeiro estudei, pesquisei e organizei os recursos materiais necessários para quando os surdos fossem visitar o acervo, explicando através de LIBRAS. Também estudei os jogos de palavras relacionadas às obras para eles aprenderem a língua portuguesa. Como sou surda, minha comunicação com este público era muito eficaz e me permitiu uma comunicação direta como eles. Assim desenvolvi a minha experiência profissional com os surdos visitantes de museus. Em 2005 comecei a trabalhar como Educadora para Surdos no Museu de Numismática do Itaú Cultural, explicando os contextos históricos das moedas e outras atividades como as moedas ampliadas para crianças surdas. Voltei a trabalhar como Educadora para surdos na Pinacoteca do Estado, uma vez por semana, em parceria com o Itaú Cultural. Também na Prefeitura, pelo SEPED, trabalhei como Pesquisadora de Formação de Educadores Surdos, uma vez por semana. Isso possibilitou o começo de um projeto de curso de formação de Educadores Surdos para trabalhar em exposições temporárias, mas esta proposta ainda não começou de fato. Esta foi minha contribuição na inclusão de deficientes nos meios culturais.

4. Considerando políticas de acessibilidade para pessoas com deficiências em outras áreas (educação, saúde, transporte, etc.), como você analisa a condição dos museus em relação às pessoas com deficiência? Que exemplo você daria de uma prática adequada considerando os aspectos físicos, conceituais (explicações) e políticos (administrativos)?

Vejo que não tem acessibilidade em alguns museus, faltam muitas coisas para os deficientes. A maioria de museus não tem interpretes de LIBRAS, também não possuem educadores surdos. No momento eu estou percebendo que está melhorando na área da educação, pois quase todas as faculdades têm intérpretes de LIBRAS para acompanhar na sala de aula os alunos surdos. Mas falta em outros lugares, por exemplo, hospitais, museus, exposições, assessoria jurídica, cursos diversos e outros na área de lazer. Isso é muito importante para surdos se incluírem de verdade e saber mais sobre a vida cultural da cidade. O único museu de São Paulo que é realmente 
pensado para deficientes é a Pinacoteca porque tem acessibilidade, porque tem programa especial, como PEPE - Programa Educativo para Público Especial, somente todas os deficientes.

5. Como você acha que as pessoas com deficiências devem agir para incentivar a acessibilidade nos museus e outros equipamentos culturais e qual a importância de incluir este público nessa esfera sócio-cultural?

As pessoas deficientes devem se unir com as outras pessoas, sem preconceitos. É bom que toda a sociedade tenha maior conhecimento sobre o acesso à cultura para deficientes. Procurar as associações para deficientes e fazer documentos para os administradores dos museus, para as autoridades e órgãos do governo, ou até mesmo para museus particulares e fundações, exigindo a adaptação do museu para as necessidades dos deficientes: rampas e elevadores para cadeirantes, explicações sonoras e em Braille para os cegos, maquetes e miniaturas das obras para os cegos poderem pegar e entender a obra, intérprete de LIBRAS para Surdos, filmes nacionais legendados nos cinemas, profissionais especializados para trabalhar com deficientes mentais.

Os próprios museus deveriam propor atividades motoras e sensoriais com os visitantes para sensibilizar a população sobre as dificuldades de acesso dos deficientes às obras. Incluir os deficientes na esfera sócio-cultural é dar o direito deles poderem usufruir o lazer cultural como todos os demais cidadãos. 